\title{
O TRABALHO NA AVIAÇÃO E AS PRÁTICAS DE SAÚDE SOB O OLHAR DO CONTROLADOR DE TRÁFEGO AÉREO
}

\author{
RITA DE CÁSSIA SEIXAS SAMPAIO ARAUJO
}

Dissertação de Mestrado apresentada ao Departamento de Saúde Ambiental da

Faculdade de Saúde Pública da Universidade de São Paulo para obtenção do título de Mestre

Área de Concentração: Saúde do Trabalhador Orientador:Prof. Dr. René Mendes

SÃO PAULO

2000 
Dedico este trabalho ao Flavio, e a todos os seres, desde a primeira forma de vida que surgiu, que me possibilitaram nascer, viver e ser.

Aos nossos filhos, humanidade futura, razão e objetivo de nossas vidas...

A todos que sonham e trabalham por um mundo melhor. 


\section{AGRADECIMENTOS}

A realização deste estudo não teria sido possível sem o apoio e sem as valiosas contribuições de muitos profissionais de várias instituições, colegas e amigos, aos quais expresso meus profundos agradecimentos.

Em particular, os agradecimentos vão aos trabalhadores que lutam com esperanças por seus sonhos...

Aos amigos que ao longo destes quatro anos me incentivaram e apoiaram.... especialmente Rosilda, Laps, Luiza, Jorge, Fernando e Ana, Daniel.

À Alice por ter acreditado em mim... ajudando-me a (re)significar a vida... 


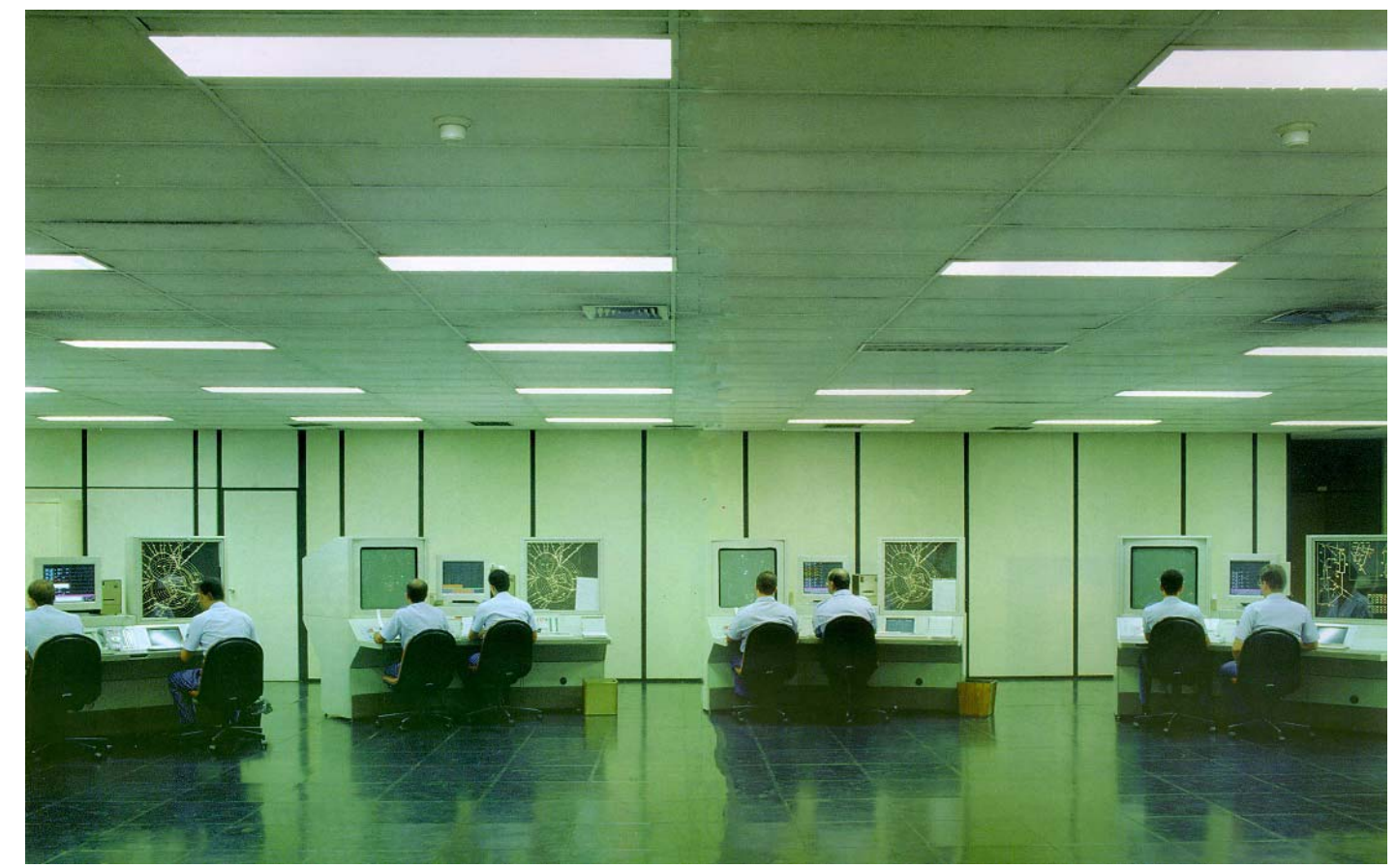

Sala de Controle de Tráfego Aéreo da Terminal São Paulo

Aeroporto de Congonhas 


\section{RESUMO}

Araújo RCSS. O Trabalho e as Práticas de Saúde do Controlador de Tráfego Aéreo. São Paulo; 2000. [Dissertação de Mestrado - Faculdade de Saúde Pública da USP].

Os profissionais do controle de tráfego aéreo desenvolvem uma função de importância para a sociedade. Neste sentido, realizou-se estudo com objetivo de analisar as representações sociais dos controladores de tráfego aéreo sobre sua saúde e sobre as práticas de saúde desenvolvidas pelo Sistema de Saúde da Aeronáutica, tendo em vista uma possível contribuição para a adoção de práticas de promoção e proteção da saúde e segurança da aviação. Desenvolveu-se um estudo qualitativo, utilizando-se a técnica do Discurso do Sujeito Coletivo (DSC), por meio de entrevistas semi-estruturadas, com 12 participantes do Controle de Aproximação da Área Terminal São Paulo. Foi possível caracterizar, em primeiro lugar, o funcionamento do Controle Tráfego Aéreo neste Terminal e, em segundo lugar, conhecer as representações sociais destes trabalhadores sobre o trabalho no Controle de Tráfego; a experiência com o risco no cotidiano do trabalho; as relações do controlador com a hierarquia militar; os rumos possíveis para o trabalho no controle de tráfego aéreo e das práticas de saúde destes trabalhadores. Pôde-se observar a existência de dificuldades em se produzir qualquer alteração de ordem sistêmica e administrativa. O aspecto da tecnologia aparece como relevante e, em muitas situações, as falhas no sistema são apontadas como geradoras de risco. No entanto, tornou-se evidente que o controle de tráfego aéreo é muito mais um problema social e institucional, uma vez que existem interesses diversos dos diferentes atores envolvidos: trabalhadores, aeronáutica, companhias aéreas e usuários. A incorporação do saber do trabalhador por meio da metodologia do DSC permitiu o acesso a uma cultura organizacional, qualitativamente diferente da "coletividade matemática", e que deve ser conhecida antes de qualquer intervenção no campo da Saúde do Trabalhador. 


\section{SUMMARY}

Araújo RCSS. O Trabalho e as Práticas de Saúde do Controlador de Tráfego Aéreo. [The Work and Health Practices of Air Traffic Controllers] São Paulo(BR); 2000. [Dissertação de Mestrado - Faculdade de Saúde Pública da USP].

Air traffic controllers develop a real important activity for society. In this sense, the present study analyses the air traffic controllers social representations about their health and the health practices offered by the Aeronautic Health System, aiming at contributing for the decisions on adoption of practices for promoting and protecting aviation health and safety. This qualitative study, based on the Collective Subject Discourses (DSC), was carried out usure semi-structured interviews with 12 participants working at "Approximation Control Area of São Paulo Terminal". The research allowed the characterisation of the work context and of the workers' social representations about the work control, their experiences with daily risk, health conditions and practices, relationship with the military hierarchy and possible directions for the air traffic control. The study showed a great difficulty of implementing any system or administrative changes. Technology is a relevant aspect pointed as generating risk in many occurrences of system failure. Nevertheless, the air traffic control seems to be much more a social and institutional problem. There are several other different interests of the actors involved: workers, aeronautic, air companies and users. The DSC methodology allowed us to approach an organisational culture qualitatively different from other quantitative studies, and that should be known before any intervention in the work health field. 


\section{ÍNDICE}

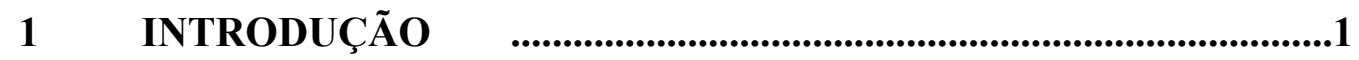

1.1 Condições de risco no transporte aéreo …........................................ 1

1.2 Contexto do Tráfego aéreo no Brasil.......................................................

1.3 Aspectos da regulamentação do controle de tráfego aéreo ...................9

1.4 Visão sistêmica do controle do espaço aéreo no Brasil ...................11

1.5 Caracterização do Controlador de Tráfego Aéreo .............................13

1.6 O desgaste do Controlador de tráfego aéreo.........................................14

1.7 Condições de risco na organização do trabalho do controlador de tráfego

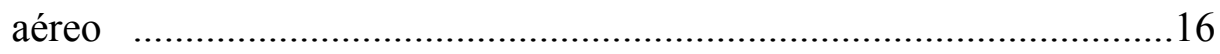

1.8 Condições de Risco para a Sociedade $\quad$..........................................17

2 OBJETIVOS DO ESTUDO …..............................................21

3 PRÁTICAS E RISCOS À SAÚDE - REFERENCIAIS TEÓRICOS...22

3.1 A Saúde do Trabalhador …........................................................22

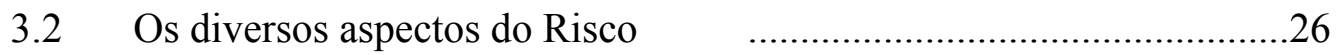

3.3 As condições de riscos à saúde dos controladores de vôo ……..........28

3.4 Os agravos à saúde do controlador de tráfego aéreo ............................30

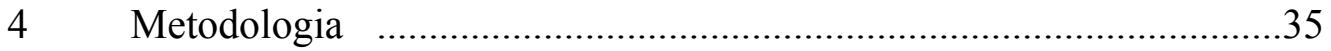

4.1 Pesquisa qualitativa: justificativa da escolha.....................................35

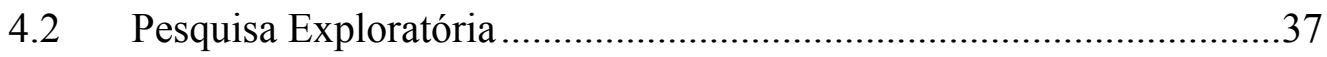

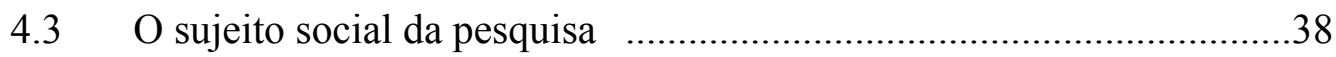

4.4 Elaboração do instrumento de pesquisa $\quad$.........................................39

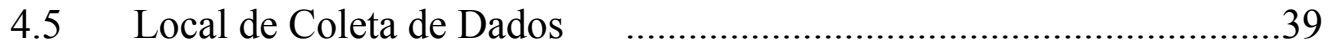

4.6 Termo de Consentimento dos Sujeitos _.......................................39

4.7 Instrumento de Coleta de Dados …...............................................40

4.8 Técnica de Análise de Dados ..............................................................41

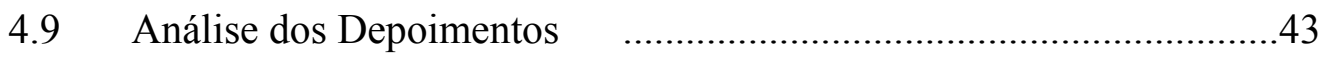

5 RESULTADOS E DISCUSSÃO …...............................................45

6 CONSIDERAÇÕES FINAIS $\quad$..............................................104

$7 \quad$ REFERÊNCIAS $\quad$................................................................110 


\section{ANEXOS}

Anexo 1 - Transcrição de fita sobre as condições de operação no aeroporto de Congonhas

Anexo 2 - Informe sobre realização do debate na UNESP

Anexo 3 - Entrevista concedida ao jornal da USP

Anexo 4 - Informe sobre a entrevista ao jornal da USP

A4

Anexo 5 - Roteiro de Entrevista

A5

Anexo 6 - Termo de Consentimento

A6

Anexo 7 - Instrumento de análise de discurso 1 (IAD1)

A7

Anexo 8 - Instrumento de análise de discurso 2 (IAD2)

A8 


\section{QUADRO DE ACRÔNIMOS}

Com o objetivo de facilitar a compreensão e entendimento do presente estudo, a seguir, uma listagem com as principais abreviaturas utilizadas na operação do controle de tráfego aéreo:

$\begin{array}{ll}\text { ABM } & \text { - Través } \\ \text { ACC } & \text { - Centro de Controle de Área } \\ \text { ACFT } & \text { - Aeronave } \\ \text { AD } & \text { - Aeródromo } \\ \text { AFIS } & \text { - Serviço de Informação de Vôo de Aeródromo } \\ \text { AFS } & \text { - Serviço Fixo Aeronáutico } \\ \text { AGL } & \text { - Acima do Nível do Solo } \\ \text { AIP } & \text { - Publicação de Informações Aeronáuticas } \\ \text { AIREP } & \text { - Aeronotificação } \\ \text { ALS } & \text { - Sistema de Luzes de Aproximação } \\ \text { APP } & \text { - Controle de Aproximação } \\ \text { ARC } & \text { - Carta de Área } \\ \text { ARP } & \text { - Aeronotificação (designador de tipo de mensagem) } \\ \text { ARR } & \text { - Chegada } \\ \text { ARS } & \text { - Aeronotificação Especial (designador de tipo de mensagem) } \\ \text { ASC } & \text { - Subindo ou Suba } \\ \text { ASR } & \text { - Radar de Vigilância de Aeroporto } \\ \text { ATC } & \text { - Controle de Tráfego Aéreo } \\ \text { ATIS } & \text { - Serviço Automático de Informação Terminal } \\ \text { ATS } & \text { - Serviço de Tráfego Aéreo } \\ \text { ATZ } & \text { - Zona de Tráfego de Aeródromo } \\ \text { AWY } & \text { - Aerovia } \\ \text { CCES } & \text { - Centro de Controle de Emergência e Segurança } \\ \text { CINDACTA } & \text { - Centro Integrado de Defesa Aérea e Controle de Tráfego Aéreo } \\ \text { COM } & \text { - Comunicações } \\ \text { CopM } & \text { - Centro de Operações Militares } \\ \text { CTA } & \text { - Área de Controle } \\ \text { CTR } & \text { - Zona de Controle } \\ \text { DA } & \text { - Altitude de Decisão } \\ \text { DES } & \text { - Descendo ou Desça } \\ \text { DEPV } & \text { - Diretoria de Eletrônica e Proteção ao Vôo } \\ \text { DH } & \text { - Altura de Decisão } \\ \text { DME } & \text { - Equipamento Radiotelemétrico } \\ \text { ERC } & \text { - Carta de Rota } \\ \text { ETA } & \text { - Hora Estimada de Chegada } \\ \text { ETD } & \text { - Hora Estimada de Partida } \\ \text { ETO } & \text { - Hora Estimada de Sobrevôo } \\ \text { FIR } & \text { - Região de Informação de Vôo } \\ \text { FIS } & \text { - Serviço de Informação de Vôo } \\ \text { FL } & \text { - Nível de Vôo } \\ \text { FPL } & \text { - Mensagem de Plano de Vôo Apresentado } \\ \text { GCA } & \text { - Sistema de Aproximação Controlada de Terra } \\ \text { IAC } & \text { - Carta de Aproximação e de Pouso por Instrumentos } \\ \text { IAS } & \text { - Velocidade Indicada } \\ \text { IEMA } & \text { - Impresso Especial do Ministério da Aeronáutica } \\ \text { IEPV } & \text { - Impresso Especial da Proteção ao Vôo } \\ & \end{array}$




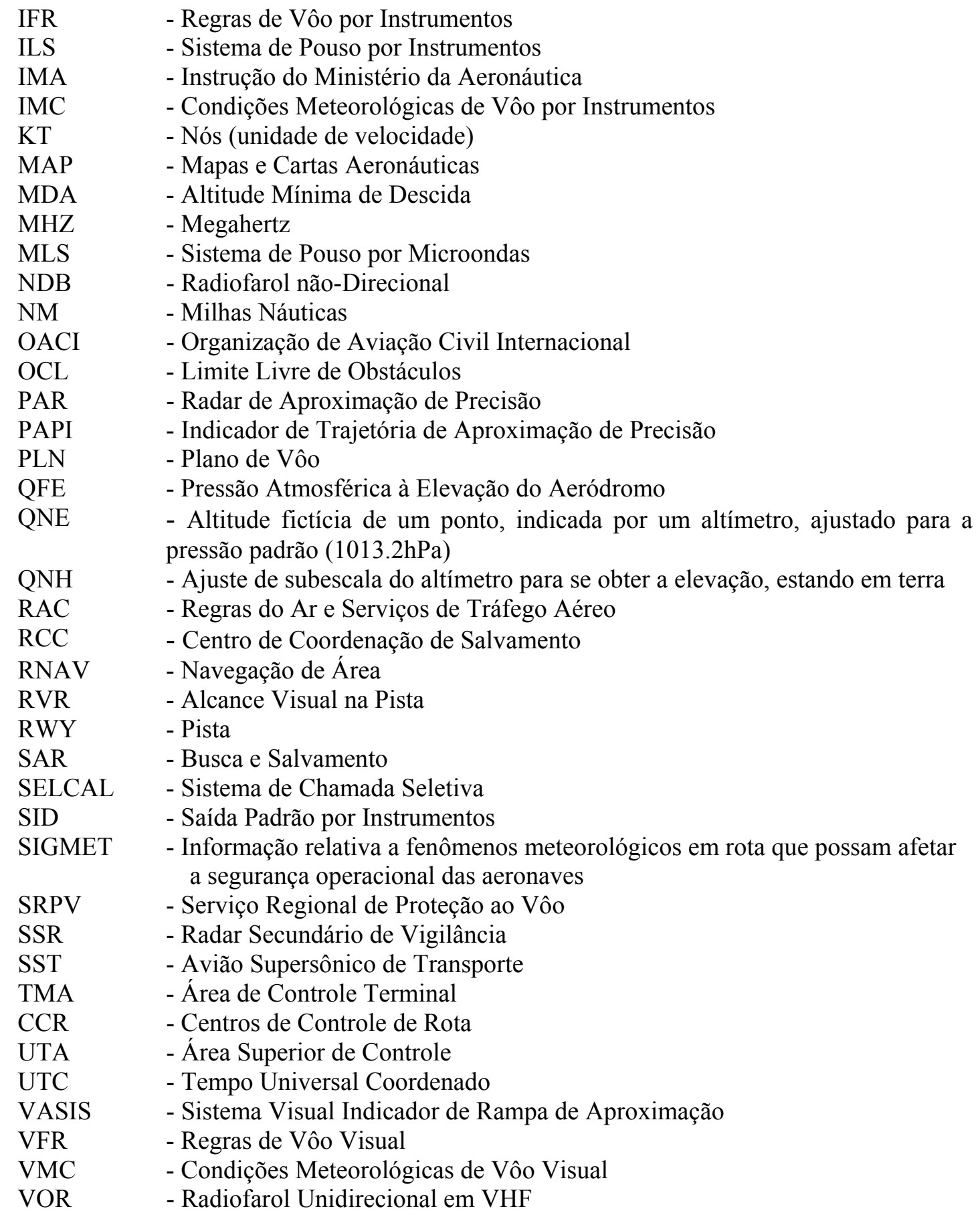




\section{APRESENTAÇÃO}

Todos os dias, em todos os cantos do país e do mundo, pessoas acordam, tomam seu café da manhã e partem para mais um dia de trabalho.

Alguns não voltam... Os meios de transporte que os conduzem podem variar: trem, ônibus, carro, metrô, avião.

Mas qualquer que seja ele, parte-se do princípio de que todas as providências tenham sido tomadas para o bom funcionamento destes equipamentos e que os trabalhadores tenham condições de vida satisfatórias, que lhes possibilitem executar seu trabalho com eficiência e responsabilidade.

O risco no transporte não pode ser atribuído a uma ação essencialmente individual. Existem ambientes de risco que afetam coletivamente grandes massas de indivíduos. Existe aí uma relação direta entre a segurança dos meios de transporte e a Saúde do Trabalhador que opera estes sistemas.

Inserida na área de Saúde do Trabalhador há mais de uma década, venho almejando, em minha trajetória profissional, compreender o processo saúde-doença e trabalho e suas determinações sociais. Os trabalhadores da aviação: comissários de bordo, comandantes, controladores de vôos têm manifestado preocupação com as condições em que trabalham e suas possíveis conseqüências. São personagens que vivem o risco em ambientes de trabalho que não podem prescindir da imagem da "impecabilidade".

Este estudo tem por finalidade verificar se as práticas de saúde preconizadas para os trabalhadores da aviação civil brasileira estão sendo eficazes para a prevenção de agravos à saúde do controlador de tráfego aéreo.

A escolha pelo controlador de tráfego aéreo, para a presente pesquisa, é decorrente de uma longa trajetória de aproximação com o universo representacional dos riscos no céu... dos traços de morte... das ameaças à vida... Neste cenário, os controladores são aqueles que têm o dever e a responsabilidade permanente de tudo controlar no sistema. São trabalhadores invisíveis para a sociedade. Mas, de seu autocontrole e auto-exigência dependem a tomada de decisões corretas.... E a vida de muitas pessoas.

No seu cotidiano de trabalho, o "controla-a-dor" é o trabalhador que tudo controla, até a própria dor. A auto-exigência parece contribuir para que os próprios 
controladores participem da invisibilização de seus males e do desgaste acarretado pelo trabalho. Deste modo, pode-se perceber que, ao longo do tempo, esta exigência de autocontrole interage com o seu ser e na forma como se expressa ao mundo. Seres insensíveis? Frios? Duros?

Uma das categorias profissionais mais implicadas na segurança aérea, respondem pela coordenação e separação dos vôos no espaço; com equipes reduzidas, sem contar com um programa de reciclagem ou requalificação permanente; lidam com uma complexa e frágil gestão do tráfego aéreo... Essa fragilidade do controle de tráfego aéreo representa a multiplicação do potencial de risco dos atuais sistemas da aviação civil, colocando em perigo a vida dos passageiros e aeronautas a bordo. Sem contar os riscos à população residente no entorno dos aeroportos.

O presente estudo será realizado com os operadores do Centro de Controle de Tráfego, localizado no Aeroporto de Congonhas em São Paulo. 


\section{INTRODUÇÃO}

\subsection{CONDIÇÕES DE RISCO NO TRANSPORTE AÉREO}

Neste estudo, pretende-se trazer para o âmbito da saúde pública, particularmente para o campo da saúde do trabalhador, o contexto geral das condições de vida e saúde dos trabalhadores que atuam nos centros de controle de tráfego aéreo - Centro de Controle de Aproximação, denominado APP, nome derivado da palavra "approach". Procura-se, ainda, compreender as práticas em saúde e entender suas ações como processos de intervenção técnica e social na realidade de saúde, buscando inspirar-se em instrumentos da pesquisa qualitativa (SCHRAIBER e MENDES-GONÇALVES 1996).

Serão priorizadas as possibilidades de reiterar, nos distintos planos das práticas de saúde, a influência do trabalho na saúde do indivíduo. Para analisar a relação trabalho-saúde, é preciso compreendê-la como forma de interação produtiva entre o ser humano, a natureza e a sociedade (BRAVERMAN 1987).

O desenvolvimento de análises voltadas à preocupação perante a vida, a saúde e a segurança do ser humano não tem respondido às exigências das novas formas do trabalho. Existe aí uma correlação desigual de forças que, historicamente, tem se mostrado desfavorável aos trabalhadores (FERRETI e col. 1994). Da sociedade primitiva à contemporânea, as formas de trabalho sofreram profundas modificações, principalmente com a incorporação de novas tecnologias e sistemas automatizados. A sociedade ainda não consegue garantir, como resultado do embate entre a ansiedade coletiva de absorver novos benefícios do desenvolvimento e a necessidade da preservação dos indivíduos que o promovem, uma relação justa e humana (BRUNO 1996).

O conhecimento das experiências que são vividas pelos trabalhadores dos serviços de transporte, no contexto da Saúde do Trabalhador, pode ser ampliado por meio do uso de metodologia qualitativa, que permite conhecer os processos de saúdedoença destes profissionais. Estes processos são delimitados pelos modos cotidianos de viver a vida social desta população, que se constitui como grupos homogêneos do ponto 
de vista societário, conformando-se, em parte, com base nos padrões epidemiológicos que podem ser também detectados (SCHRAIBER e MENDES-GONÇALVES 1996).

Os novos modelos de organização do trabalho no setor do transporte vêm submetendo os trabalhadores a situações críticas. Os operadores destes serviços estão cada vez mais expostos a condições de trabalho em que nem sempre os riscos à saúde são facilmente identificáveis. ITANI (1998 p. 112) afirma que “(...) trabalhar na produção do serviço de deslocamento de pessoas com os atuais sistemas de informação é trabalhar com a velocidade e é também viver o tempo em dimensões diferenciadas". A autora observa que, associada a essa vivência de dimensões de tempo, o operador precisa estar sempre pronto a viver tais dimensões com atenção permanente, pois dele é exigida uma necessária prontidão, para fazer frente a uma possibilidade sempre presente da reversibilidade da oscilante situação de normalidade-anormalidade.

No setor do transporte aéreo, a imprevisibilidade aumenta a necessidade de atenção permanente do trabalhador, situação que se torna mais crítica diante do crescimento deste importante segmento da economia. Este setor, beneficiando-se do desenvolvimento das inovações tecnológicas dos sistemas de informação e de comunicação, vem conseguindo deslocar progressivamente maior quantidade de passageiros por viagem. Além do crescimento da quantidade de passageiros por vôo, a modernização acelerada da aviação civil ocasionou o aumento da velocidade das aeronaves, o que se acentua com as tecnologias automatizadas.

Outro aspecto a ser considerado refere-se ao aumento do número de aeronaves que circulam anualmente no espaço aéreo. Apesar da melhora contínua no desempenho dos equipamentos, demonstrando uma segurança duas a três vezes superior à da geração precedente, é preocupante a constatação de que o número bruto de acidentes tem aumentado proporcionalmente ao crescimento do volume de vôos. Esta constatação é chamada assíntota de segurança - a taxa de segurança não consegue aumentar há vários anos. De fato, na Aviação Civil Internacional, o nível de segurança se mantém estável, como mostra a Figura 1. 
Figura l - Comportamento da taxa de acidentes aéreos no mundo. em 1999.

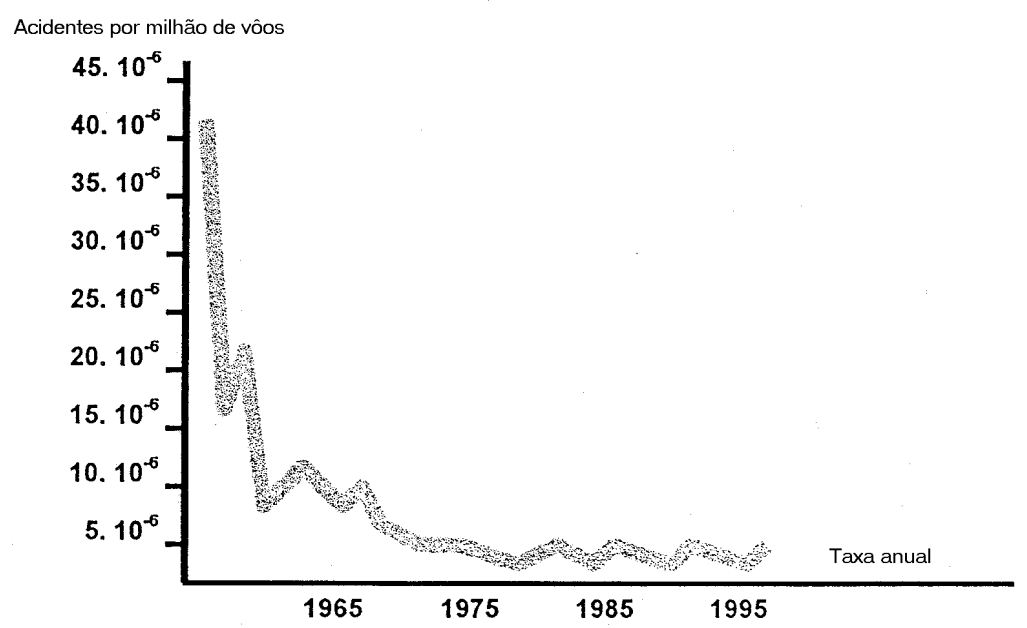

Fonte:Dados dos relatórios de pesquisas ergonômicas realizadas no controle de tráfego aéreo do Rio de Janeiro,

Como o nível de segurança é calculado em função do número de acidentes por milhão de vôos realizados, e o volume de vôos tem crescido sempre, segundo a análise de VIDAL e MOREIRA (1999), se o Sistema de Transporte Aéreo Internacional tem permanecido com uma taxa de acidentes estabilizada, isto só pode se dever a um aumento no número bruto de acidentes anuais, o que pode ser constatado na Figura 2.

Figura 2 - Número de acidentes aéreos no mundo

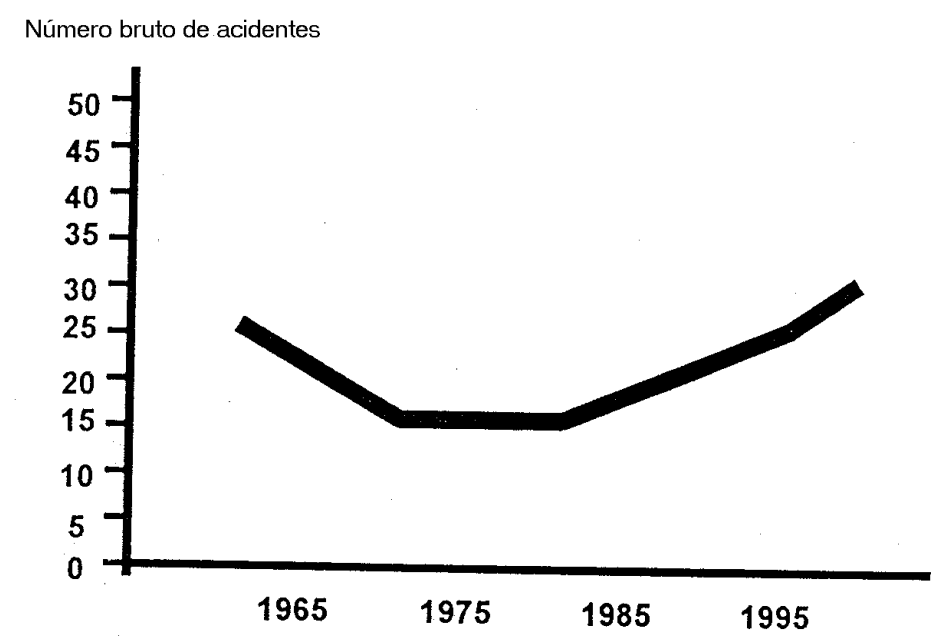

Fonte:Dados dos relatórios de pesquisas ergonômicas realizadas no controle de tráfego aéreo do Rio de Janeiro, em 1999. 
Segundo se observa na Figura 1, a taxa de acidentes vem se mantendo constante desde 1970. Concorda-se com a hipótese de VIDAL e MOREIRA (1999), que atribui à enorme sofisticação do sistema esta estabilidade. Talvez, o sistema já tenha atingido o seu índice máximo possível em termos de segurança, uma vez que só há duas maneiras de aprimorar esta taxa - reduzindo-se o número de vôos ou reduzindo-se o total bruto de acidentes.

Figura 3 - Previsão da evolução dos acidentes aéreos no mundo

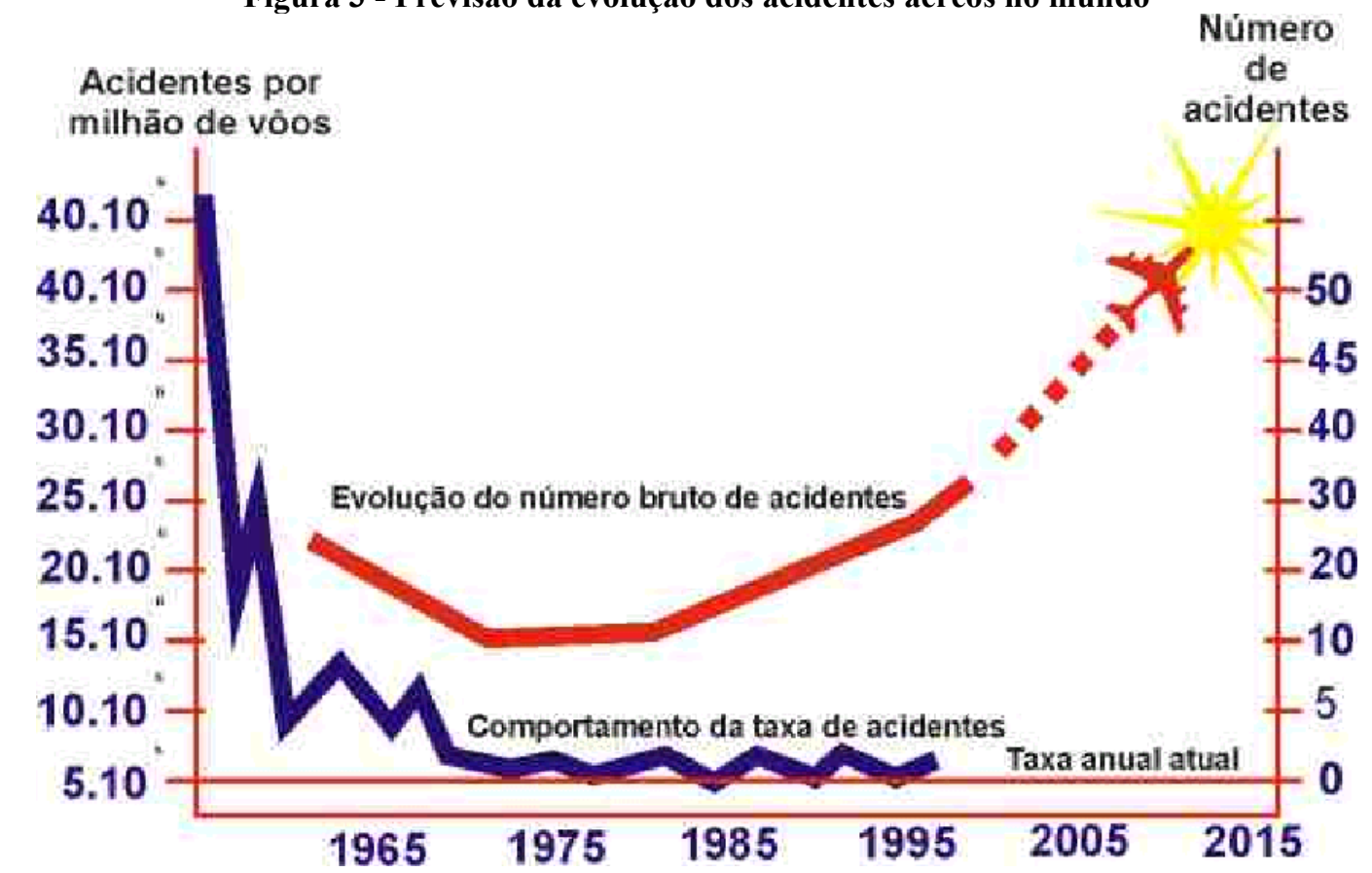

Fonte: Dados dos relatórios de pesquisas ergonômicas realizadas no controle de tráfego aéreo do Rio de Janeiro, em 1999.

Conforme a análise dos dados contidos na Figura 3, prevê-se que o crescimento do transporte aéreo seja constante nos próximos anos, uma condição necessária à sobrevivência do atual modelo da aviação comercial. Objetivamente, isto significa um aumento de $100 \%$ do tráfego até o ano de 2010 . Portanto, se hoje o número absoluto de acidentes graves se situa na faixa de 25 a 30 por ano, prevê-se que deverá ultrapassar 50 por ano em 10 anos, o que também pode ser observado na Figura 3.

A conjunção de diversos fatores vem potencializando a possibilidade de ocorrência de acidentes e desastres de grandes proporções e aumentando, por conseguinte, o patamar de riscos a que ficam expostas as tripulações a bordo, 
passageiros das aeronaves, comunidades das cercanias de rotas e aeroportos e o meio ambiente.

Deve ser ressaltado que, no caso brasileiro, tomando-se para análise o período de 1979 a 1999, os dados divulgados mostram uma redução no número de acidentes aéreos, conforme se pode observar na Figura 4. No entanto, o número de mortes nesse tipo de acidentes tem aumentado, encontrando-se um coeficiente de fatalidade de $0.495 \mathrm{em}$ 1979; de 0.603 em 1989 e de 1.26 em 1999, segundo dados do Departamento de Aviação Civil, Brasil, 2000. Destaca-se o ano de 1996, em que este coeficiente atingiu 2.16, principalmente em razão dos acidentes aéreos de grande repercussão que ocorreram naquele ano vitimando mais de uma centena de pessoas.

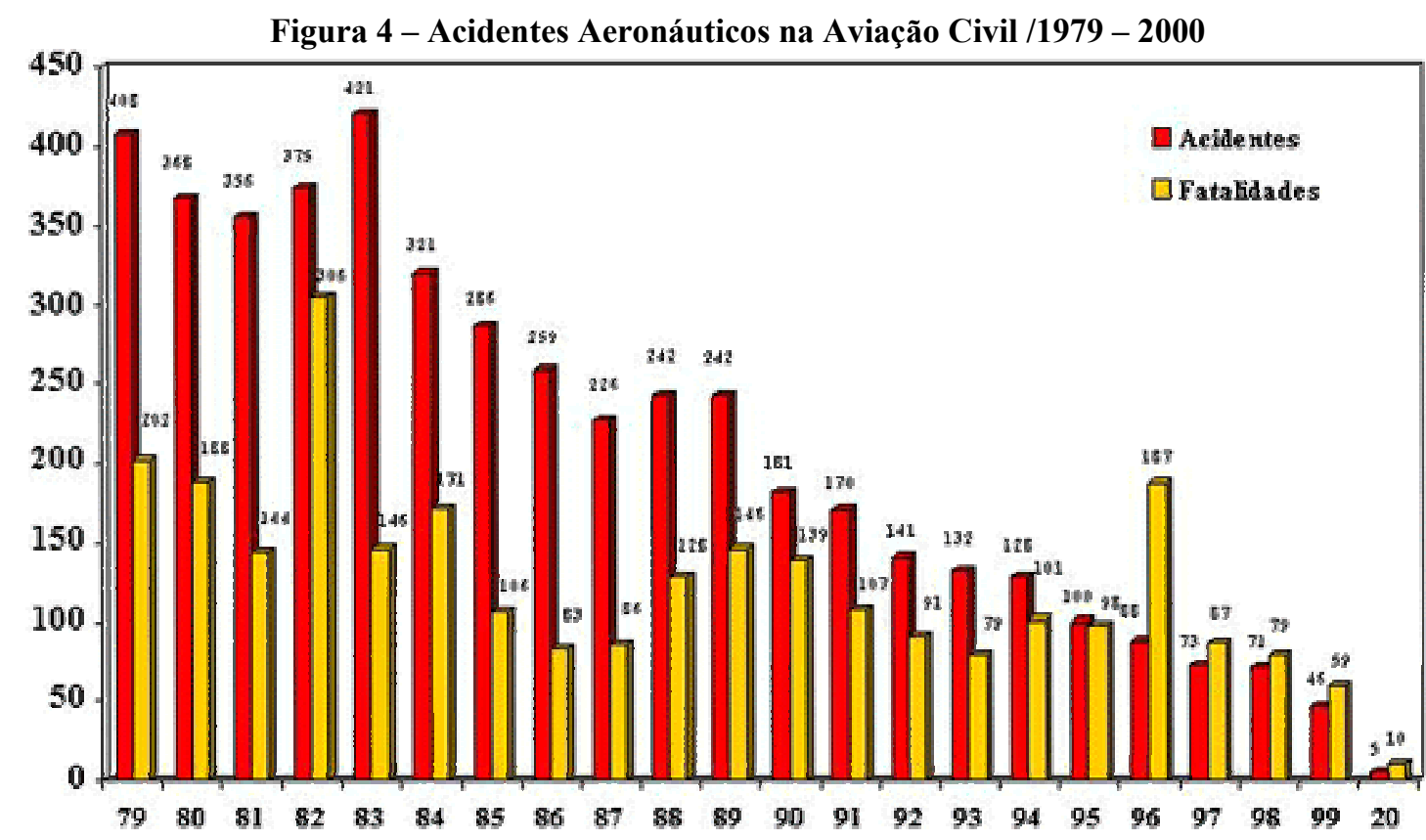

Fonte: Departamento de Aviação Civil.[on line] www.gov.br

Dados registrados até 07 de janeiro de 2000.

\subsection{Contexto do Tráfego AÉreO no Brasil}

Sobre o espaço aéreo brasileiro, na área delimitada acima do território e mar territorial nacional, transitam atualmente, por via aérea, cerca de 50 milhões de passageiros/ano, dos quais mais de 26 milhões de pessoas são embarcadas anualmente no Brasil. Nesta categoria de transporte, o ramo que mais se desenvolveu foi o do 
tráfego aéreo regional, no segmento de vôo doméstico, que cresceu $600 \%$ nos últimos oito anos (considera-se vôo doméstico todo transporte em que os pontos de partida, intermediários e de destino estejam situados em território nacional).

No início dos anos noventa, os vôos aéreos domésticos transportavam por ano 1,5 milhões de passageiros, através de cinco empresas, cinco anos depois (em 1996), esse número chegava a quase 6 milhões de passageiros. Nesse total, também deve ser contabilizado cerca de 1,6 milhão de pessoas transportadas através da ponte aérea São Paulo/Rio de Janeiro/ São Paulo, onde ocorre o maior movimento, tanto em número de passageiros transportados, como em número de deslocamentos de aeronaves/ dia ${ }^{1}$.

Muito embora se possa observar uma perda de passageiros nos vôos domésticos brasileiros, ocorreu uma reorganização do processo produtivo no setor, com o surgimento do ramo aéreo regional e o aumento da procura de vôos internacionais, possibilitado especialmente pelo aspecto custo. Isso sem contar o crescimento de empresas de táxi aéreo ${ }^{2}$.

É fato que o crescimento desse setor vem junto com o aumento da capacidade dos equipamentos em transportar uma maior quantidade de passageiros. Atualmente, alguns aviões chegam a transportar 400 passageiros, como é o caso do Boeing 747-400. Há também o MD-11, que comporta mais de 300 passageiros. No transporte regional, vem sendo utilizado tanto o Boeing 737 como o Fokker 100, que transportam mais de 100 passageiros. Isso significa que houve um aumento de assentos passageiros $/ \mathrm{km}$, de cerca de 200\% nos últimos 15 anos (ITANI 1998).

O transporte aéreo também se beneficiou do aumento da velocidade, privilegiado pelos novos sistemas e equipamentos, a partir dos anos 60, com a introdução do jato. Nos últimos seis anos, a velocidade média registrada na aviação passou de 680 para 723 quilômetros por hora no tráfego nacional, e de 320 para 405 no regional. Paralelamente, houve uma mudança total da frota nos últimos 20 anos. No tráfego nacional, em 1986,

1Dados do Departamento de Aviação Civil , 1990.

2 Dados extraídos dos Anuários Estatísticos_ Departamento de Aviação Civil, 1990. 
$10 \%$ da frota utilizava turboélice; atualmente, ela é composta por jatos. Também, no tráfego regional, os táxis aéreos a jato vêm ocupando espaço (ITANI 1998).

Apesar da perspectiva de crescimento neste setor, em função do processo de desregulamentação do transporte aéreo mundial, há de um lado, uma pressão das grandes empresas internacionais na quebra das reservas de mercados nacionais. De outro lado, as empresas nacionais, para tentar responder a essa pressão, vêm reduzindo as tarifas aéreas, de maneira a atender uma demanda reprimida interna e, ao mesmo tempo, enfrentar a concorrência internacional no mercado interno. Após um período de aparente estabilidade econômica, em função de medidas adotadas pelo governo no último Plano de Estabilização Econômica (Plano Real), a aviação civil no Brasil, vem apresentando sinais de crise.

Apesar das mudanças observadas no perfil da aviação civil brasileira nos últimos anos, atualmente, há sinais de dificuldades no equilíbrio financeiro do setor. As perspectivas apontam redução do número de companhias aéreas, com propostas de "fusão" entre empresas ou, ainda, redução do tamanho. As tendências verificadas em relação ao transporte aéreo na atualidade são, entre outras, a de flexibilização e globalização deste serviço, com crescimento do setor, principalmente por meio do aumento da participação de capital estrangeiro (Folha de São Paulo 2000).

Neste contexto, ampliam-se as exigências na implementação de diretrizes de planejamento que minimizem os impactos do crescimento deste setor, especialmente em sistemas de controle de tráfego aéreo.

Numa análise retrospectiva do tráfego do ano de 1996, observa-se que o sistema de transporte aéreo civil transportou, nos tráfegos doméstico e internacional, cerca de 61 bilhões de passageiros/km (passageiros transportados x etapa média) e 2,5 bilhões de toneladas/km de carga (toneladas de carga e mala postal transportadas x etapa média). As previsões para o início do próximo século estão em torno de 82 bilhões de passageiros $/ \mathrm{km} /$ ano e 4 bilhões de toneladas $/ \mathrm{km}$ de carga/ano. Se o crescimento da demanda mantiver este ritmo, o sistema estará transportando 331 bilhões de 
passageiros/km e 18 bilhões de toneladas/km de carga no ano 2020, ou seja, 8 vezes o volume de tráfego atual ${ }^{3}$.

Pode-se prever que este crescimento do sistema de transporte aéreo causará um grande impacto neste ramo de serviço, que envolverá várias categorias de trabalhadores da aviação civil, sejam aeronautas (profissionais que trabalham nas aeronaves), aeroviários (pessoal que trabalham em terra) e controladores de tráfego aéreo. Há uma preocupação com a reorganização dos serviços dos aeroportos decorrente da pressão dos passageiros por atendimento mais eficiente de balcão e serviços de terra, o que não ocorre com as demais atividades. Uma destas condições e, provavelmente, a mais crucial, é a do controle de tráfego aéreo, que deve estar dimensionado para atender a esse volume de tráfego futuro.

A infra-estrutura deste serviço, entretanto, não tem conseguido acompanhar esse crescimento. Segundo VIDAL e MOREIRA (1999), o controle de tráfego aéreo do Rio de Janeiro tem se deparado, por vezes, com sintomas de saturação do espaço aéreo, nas proximidades dos aeroportos da Área Terminal do RJ. A mesma situação pode ser apontada com relação à Área Terminal São Paulo. Ou seja, a segurança nas proximidades dos aeroportos que servem a "ponte aérea" é crítica em termos de riscos de acidentes. A ocorrência de atrasos nos vôos é freqüente. Esta situação pode tornar-se insuportável para as empresas aéreas, pois o custo dos atrasos pesa no balanço financeiro das companhias. Por outro lado, deve-se considerar os inconvenientes para os passageiros e demais envolvidos, como trabalhadores da aviação e até mesmo dos moradores de regiões sob rotas nas proximidades dos aeroportos.

Há algum tempo algumas categorias profissionais do transporte aéreo vêm discutindo os problemas de segurança de vôo em função da política de minimização de recursos que vem sendo praticada no setor, até com situações críticas, com descumprimento de Normas e Regulamentos. A transcrição da fita relativa à matéria jornalística realizada pela rádio “Jovem Pan”, em 09/04/96, sobre as condições de

\footnotetext{
3 Cf. Dados do Plano de Desenvolvimento da Aviação Civil, PDSAC, 1997. [on line] www.gov.br
} Disponível em abril 2000. 
operação no Aeroporto de Congonhas, é flagrante (ANEXO 1). Como desdobramento deste episódio, o Ministro da Aeronáutica e o Diretor de Eletrônica e Proteção ao Vôo (DEPV) foram convocados pela Comissão de Defesa do Consumidor, Meio Ambiente e Minorias da Câmara Federal, em junho de 1996, para, em Audiência Pública, discutir a proteção ao vôo no País e esclarecer os problemas decorrentes da falta de segurança diante do congestionamento do tráfego aéreo, particularmente no Aeroporto de Congonhas, em São Paulo.

\subsection{ASPECTOS DA REGULAMENTAÇÃO DO CONTROLE DE TRÁFEGO AÉREO}

A regulamentação da navegação aérea no Brasil adota basicamente a legislação internacional editada pela Organização Internacional da Aviação Civil (OACI), procurando ajustar normas e métodos utilizados pelos países componentes da região CAR-SAM (Caribe-South América), da qual faz parte.

O Conselho da OACI é o responsável pela aprovação dos padrões, práticas e procedimentos recomendados, estudados e propostos pelas Comissões Técnicas que compõem a estrutura executiva dessa organização. Após a aprovação do Conselho, os Estados contratantes são consultados para se manifestarem, sendo então obrigados pelos termos da Convenção, a apresentar todas as modificações e suas razões, assim como a publicação na AIP Nacional (Publicação de Informações Aeronáuticas), das diferenças por eles adotadas.

O tráfego aéreo, a infra-estrutura aeronáutica e os serviços direta e indiretamente relacionados ao vôo, no Brasil, estão dispostos na Lei n ${ }^{\circ} 7565$, de 19 de dezembro de 1986, que dispõe sobre o Código Brasileiro de Aeronáutica. Para fins dos serviços de tráfego aéreo, adotam-se as Normas e Métodos recomendados pela (OACI), ressalvadas as restrições ou modificações apresentadas pelo Governo Brasileiro.

A Constituição da República Federativa do Brasil é a fonte de origem para o estabelecimento das regulamentações específicas sobre o funcionamento do Sistema de Controle do Espaço Aéreo Brasileiro (SISCEAB).

Este sistema é também regulado por uma série de regras editadas pela Diretoria de Eletrônica e Proteção ao Vôo (DEPV), responsável pela defesa aérea, sendo o tráfego 
aéreo civil e militar operado conjuntamente através do Sistema Integrado de Defesa Aérea e Controle de Tráfego aéreo (SISDACTA).

O SISDACTA atua no espaço aéreo brasileiro e nas regiões sob responsabilidade do país, decorrentes de tratados internacionais, na área de $8.511 .965 \mathrm{Km}^{2}$ de território nacional e numa área oceânica que se estende até o meridiano $10^{\circ} \mathrm{W}$, totalizando cerca de 22 milhões de $\mathrm{Km}^{2}$.

No que concerne às atividades de tráfego aéreo, o órgão responsável pelos estudos e elaboração dos diversos documentos afins é a Divisão de Gerenciamento do Tráfego Aéreo (D-ATM). Pautada na documentação e nas peculiaridades brasileiras, a D-ATM elabora e submete à apreciação da direção da DEPV os diversos manuais, instruções e folhetos que definem e tratam das variadas normas e procedimentos a serem adotados pelos órgãos que prestam os Serviços de Tráfego Aéreo e de Busca e Salvamento no País.

A DEPV, através da D-ATM, legisla, em âmbito nacional, sobre atividades relativas à prestação dos serviços de tráfego aéreo. Para isso, conta com uma série de Instruções do Ministério da Aeronáutica (IMA), Manuais (MMA), Folhetos (FMA) e demais impressos em completa obediência às normas e procedimentos internacionais estabelecidos e cujos principais constam na seguinte listagem:

- IMA 100-12 - Regras do Ar e Serviços de Tráfego aéreo.

- IMA 100-4 - Plano de Vôo.

- IMA 100-15 - Regras Especiais de Tráfego aéreo para Helicópteros.

- IMA 100-18 - Licenças e Certificados de Habilitação Técnica para CTA.

- MMA 100-31 - Manual do Controlador de Tráfego Aéreo.

- CIRTRAF 100-2 - Classificação dos Espaços Aéreos Condicionados.

- CIRTRAF 100-4 - Procedimentos para Processamento de Infrações de Tráfego aéreo.

- AIP Brasil - Generalidades, Comunicações, Meteorologia, Regras e Serviços de Tráfego aéreo, etc.

- AIP- MAP - Cartas de Decolagem e Aproximação por Instrumentos, Diagramas de Aeródromos, etc. (Este documento é componente obrigatório do conjunto de navegação aérea que todas as aeronaves nacionais devem portar, e as internacionais conhecer, quando em vôo em território brasileiro.) 


\subsection{VISÃo SISTÊMICA DO CONTROLE DO ESPAÇO AÉREO NO BRASIL}

O Sistema de Controle do Espaço Aéreo Brasileiro (SISCEAB) é responsável pelo controle da navegação aérea no espaço aéreo sob jurisdição do Brasil de forma integrada. O SISCEAB abrange todas as ações para atender às duas vertentes usuárias do Sistema, a civil e a militar, no que concerne às funções operacionais de Telecomunicações, Tráfego Aéreo, Meteorologia Aeronáutica, Cartografia e Informações Aeronáuticas e Busca e Salvamento.

Naquilo que diz respeito às atividades específicas das operações militares, o SISCEAB norteia-se pelas diretrizes estabelecidas pelo comando da Aeronáutica e pela DEPV.

O comando da Aeronáutica vem implementando o Plano de Desenvolvimento do Sistema de Controle do Espaço Aéreo (PDSCEA) - um plano de longo prazo, que tem por objetivo direcionar as ações da Diretoria de Eletrônica e Proteção ao Vôo (DEPV) e de outros segmentos inter-relacionados do setor ${ }^{4,5}$. De acordo com as declarações na imprensa e com base em informações do Departamento de Aviação Civil, o PDSCEA tem tomado como base os seguintes indicadores: crescimento do movimento do tráfego aéreo doméstico e internacional, com suas origens e destinos; projeção da demanda qualitativa e quantitativa destes movimentos; evolução tecnológica das aeronaves e dos meios de controle de tráfego aéreo e de comunicações; planos governamentais; planos da Organização de Aviação Civil Internacional (OACI); e planos de desenvolvimento deste segmento de outros países.

A seguir, com o objetivo de facilitar o entendimento sistêmico sobre o funcionamento do controle do tráfego aéreo brasileiro, toma-se, a título de ilustração, o depoimento de um operador:

"a melhor imagem deste sistema é a de uma colcha de retalhos, onde, o céu é dividido em setores, que são monitorados, normalmente por dois controladores, o principal, que faz a fonia com os pilotos, e o auxiliar, que o abastece de dados.

\footnotetext{
${ }^{4}$ CF.DAC [on line] www . dac . gov Disponível em abril de 2000.

${ }^{5}$ Cf. DAC - DEPV [on line] www. dac . gov Disponível em abril de 2000.
} 
Sempre que uma aeronave sai de um setor e entra em outro, o piloto muda a freqüência do rádio $e$ passa a responsabilidade para outro controlador, responsável por aquele outro setor." 6

Na prática, o SISCEAB é operacionalizado por meio dos Centros Integrados de Defesa Aérea e Controle de Tráfego aéreo-Cindacta I, II, III e Amazônia, que, para efeito prático, divide o país em quatro grandes áreas:

- Cindacta I - localizado em Brasília, é responsável por uma área equivalente a 1,5 milhão de km2, abrangendo os estados de São Paulo, Rio de Janeiro, Minas Gerais, Espírito Santo, Goiás, Distrito Federal e Mato Grosso. É o mais movimentado do país, sendo que oito radares fazem a monitoração destas áreas.

- Cindacta II - com sede em Curitiba, controla a região Sul, estados de Santa Catarina, Paraná e Rio Grande do Sul.

- Cindacta III - localizado em Recife, monitora a região Nordeste, estados da Bahia, Alagoas, Pernambuco, Rio Grande do Norte, Piauí e Ceará.

- Região Amazônica - só será rastreada após a implantação do Sistema de Vigilância da Amazônia (Sivam).

Nos Cindactas estão localizados os Centros de Controle de Área (ACC), que respondem pelo monitoramento do sistema a partir das Áreas de Controle Terminal (TMA), depois que a aeronave em deslocamento atinja uma altitude de 19.500 pés em rota.

$\mathrm{Na}$ área de abrangência dos Cindactas, as altitudes dos vôos devem ser superiores a 19.500 pés. O espaço aéreo compreendido acima desta altitude é denominado de aerovia superior.

Na Zona de Controle (CTR), o espaço aéreo controlado compreende as aerovias inferiores e outras partes do espaço aéreo inferior, onde se presta o serviço de Controle de Tráfego Aéreo (ATC). O Controle de Tráfego Aéreo se dá por meio do estabelecimento de áreas de controle definidas como aerovias. Estas são dispostas em forma de corredores e providas de auxílios-rádios à navegação.

\footnotetext{
${ }^{6}$ Cf. Diretoria do Sinprovôo, Sindicato Nacional dos Trabalhadores de Proteção ao Vôo.
} 
Administrativamente, o Destacamento Regional de Proteção ao Vôo (DRPV), é o setor responsável pelo trabalho realizado tanto na Sala de Controle de Tráfego aéreo (APP), como na Torre de Controle Visual (TWR). O trabalho na Torre de Controle Visual ou simplesmente no controle visual se restringe à área interna do aeroporto, onde a partir de uma distância em torno de cinco milhas da cabeceira da pista, o vetoramento das aeronaves passa a ser operado visualmente, até o alinhamento final para pouso/ decolagem. As funções do APP e da Torre Visual são distintas, mas interdependentes.

Os Serviços Regionais de Proteção ao Vôo (SRPV) estão sediados no Rio de Janeiro, Brasília, São Paulo, Recife e Curitiba, sendo responsáveis pelo controle descentralizado do tráfego aéreo das áreas terminais nas regiões leste, centro-oeste, sudeste, nordeste e sul.

A partir de uma distância de até 100 quilômetros dos aeroportos, num nível de 195 pés, as aeronaves passam a ser vetoradas, ou seja, o controle de separação passa a ser realizado pelo Controle de Aproximação (APP). Este procedimento se dá por meio de informações obtidas de radares. Neste local de trabalho foi desenvolvida a presente pesquisa.

\subsection{CaracterizaÇão do Controlador de Tráfego Aéreo}

Atualmente, no Centro de Controle de Aproximação de São Paulo (APP-SP) atuam 100 operadores. Do ponto de vista funcional-administrativo, coexistem 86 controladores militares e 14 civis (9 homens e 5 mulheres). Aparentemente, essas diferentes formas de vínculos com a instituição parecem não gerar conflitos explícitos. No entanto, a falta de regulamentação profissional da carreira do controlador de tráfego aéreo reduz um trabalho especializado a uma atividade de "menor importância", como expressam os trabalhadores.

O trabalho no controle de tráfego aéreo é desconhecido para a maioria das pessoas, muitas vezes, até pelos próprios usuários do transporte aéreo. O controlador de tráfego aéreo tem uma enorme responsabilidade, pois seu trabalho consiste em "vetorar" uma zona do espaço aéreo, de tamanho variável, denominada "setor". Ela pode conter vários segmentos de rotas aéreas e/ou uma parte da área próxima aos grandes aeroportos, 
sendo supervisionada por pelo menos dois controladores, que orientam as aeronaves que nela se encontram. Para VIDAL e MOREIRA (1999), na Europa, o controle de vôos é referido como um "artesanato intelectual".

No Brasil, o trabalhador civil é admitido por meio de concurso específico, ingressando a seguir no curso de formação e treinamento. Há exigência do segundo grau para os candidatos civis. De outro lado, a formação para os militares inicia-se com concurso para Sargento da Aeronáutica e há exigência do primeiro grau.

A diferença de salário entre militares e civis parece não ser significativa, conforme comentado pelos próprios trabalhadores. Há, no entanto, diferenças de benefícios, como licença-prêmio, "etapa alimentação", além do uso exclusivo pelos militares do serviço médico do Hospital da Aeronáutica de São Paulo (HASP). Mesmo nos casos em que há necessidade de afastamento da função por doenças relacionadas ao trabalho, o seguimento clínico é diferenciado para o controlador de tráfego civil e para o militar. O militar conta com uma retaguarda específica dentro da estrutura corporativa. O civil simplesmente recebe o diagnóstico, ficando por sua conta a realização dos exames e do tratamento médico, uma vez que não há convênio com o serviço de retaguarda especializado na corporação aeronáutica.

\subsection{O DESGaste do CONTROLAdOR DE TRÁFEgo AÉREO}

Devido ao fato de viverem a experiência dos novos processos de trabalho que derivam do aumento da quantidade de aeronaves em operação, da velocidade dessas aeronaves, do volume de passageiros no tráfego aéreo e da introdução de sistemas automatizados, os controladores de tráfego podem estar sofrendo desgastes constantes em função das condições estressantes de sua atividade profissional, que resultam em um trabalho pouco visível, não valorizado social e financeiramente e quase desconhecido. Esta questão constitui-se no estímulo à busca da compreensão deste universo de trabalho.

Comumente, o efeito da condição de trabalho é percebido pelos operadores ao final da jornada, quando expressam a sensação de fadiga física. Os sinais de fadiga podem ser detectados através da avaliação do gasto energético e custo cardíaco relativo, 
em função do volume de tráfego em vigilância. Segundo VIDAL e MOREIRA (1999), a avaliação regular desses fatores é fundamental para a manutenção da capacidade física e da eficiência dos controladores, além de assegurar a saúde deste trabalhador a longo prazo.

O estresse psicológico, decorrente de condições variadas quanto às exigências do trabalho, tais como: dificuldades de comunicação entre controladores e pilotos, controladores e supervisores, trabalho em turnos alternados e pausas para descanso estabelecidas de forma não regular e não sistemática, elevados níveis de exigência de memória e percepção mental, faz com que estes operadores mostrem maior incidência de sintomas de estresse em relação a outras categorias profissionais. Estes sintomas foram estudados por DELL'ERBA, VENTURI, RIZZO, PORCU', PANCHERI (1994).

De acordo com HOPKIN (1988), o trabalho em turnos pode contribuir para aumentar dificuldades familiares também associadas ao estresse; preocupações financeiras e falta de reconhecimento profissional, entre outras, exigem deste trabalhador uma grande capacidade pessoal para lidar com estes desafios. Como decorrência, o quadro de instabilidade emocional, depressão, com maior falta de concentração e dificuldade de julgamento pode implicar conseqüências nefastas na operação dos sistemas de controle do tráfego aéreo.

Aponta-se ainda, a necessidade da realização de estudos ergonômicos sobre o equacionamento dos espaços de trabalho e de uma concepção da disposição dos instrumentos operados pelo trabalhador, à luz do conhecimento de medidas antropométricas específicas. Considerando-se que um indivíduo não é idêntico a outro e nem permanece idêntico ao longo do tempo (VIDAL e MOREIRA 1999). Os fatores de variação individual mais conhecidos são: idade, gênero, padrão socioeconômico, nacionalidade, deficiências de diversas ordens, constituição corporal, entre outros.

Por outro lado, deve-se considerar a demanda cognitiva decorrente da atividade de vigilâncias sobre as aeronaves. Neste sentido, a análise ergonômica do trabalho (AET) pode ser utilizada como instrumental que permite conhecer a carga representada pelas comunicações radiofônicas, quantificadas pela duração e frequência das mensagens, pela duração e frequência dos intervalos entre as mesmas e pelo idioma 
empregado. VIDAL e MOREIRA (1999), descrevem quantitativamente a distribuição das comunicações controle-aeronave no APP-RJ em $1999^{7}$.

O depoimento de um controlador de tráfego pode retratar com riqueza de detalhes uma das situações de estresse e sofrimento mental, vividas no cotidiano destes trabalhadores:

"O pior momento na vida de um controlador de vôo é ver na tela do monitor dois pontos se fundirem, caso esses pontos, que representam duas aeronaves, estejam em níveis aproximados de altitude. Nesse instante, o controlador sua frio, seu coração dispara e os olhos ficam imóveis, a espera do que vai se suceder. O susto só passa se, segundos depois, os dois se separam e verifica-se que o choque entre as duas aeronaves não ocorreu”.

Este depoimento foi colhido no projeto de estudo sobre as Condições de Trabalho e Saúde dos Controladores de Tráfego Aéreo, parte de uma pesquisa desenvolvida pela Universidade Estadual Paulista-Unesp, desde março de 1998, cuja realização atendeu à solicitação do Sindicato Nacional dos Trabalhadores da Proteção ao Vôo, no momento em que se debatia a questão dos acidentes e incidentes aéreos que ocorreram em 1996 e 1997, em São Paulo.

Tal projeto de estudo integrado está voltado à saúde do trabalhador e caracterizase pela interinstitucionalidade, com a participação de técnicos da Delegacia Regional do Trabalho de São Paulo-DRT-SP, do Centro de Referência em Saúde do Trabalhador do Estado de São Paulo-CEREST-SP, Centro de Referência em Saúde do Trabalhador da Lapa, da Secretaria de Saúde do Município de São Paulo - CRST - Lapa.

\subsection{CONDIÇÕES DE RISCO NA ORGANIZAÇÃO DO TRABALHO DO CONTROLADOR DE TRÁFEGO AÉREO}

As inovações tecnológicas introduzidas nos sistemas de transportes coletivos, especialmente no controle de tráfego, com equipamentos cada vez mais velozes e avançados, implicaram em conseqüências para a saúde dos operadores (SELIGMANN-

\footnotetext{
7 Cf. Vidal e Moreira em artigo: Comunicações radiofônicas entre aeronaves e Controle de Tráfego Aéreo do Rio de Janeiro: um aspecto da carga laboral dos radaristas em 1999.
} 
SILVA, 1994 p. 107). Esta autora afirma que o conhecimento técnico foi posto ao alcance dos controladores, mas as informações do aspecto organizacional, os projetos sobre suas próprias carreiras, a participação em decisões administrativas ficaram sempre restritas aos altos escalões. Perdendo-se, "a liberdade do pensar", essencial para que a inteligência possa manter-se ativa e criativa, em um clima propício à geração do comprometimento e do interesse pela atividade desenvolvida.

Os controladores de tráfego aéreo têm o dever e a responsabilidade permanente de tudo controlarem neste sistema, mas o que se percebe no cotidiano do trabalho destes operadores é que se sentem desvalorizados profissionalmente. "Sentir-se desqualificado para o trabalho parece ser comum em nosso tempo, o que atinge a identidade de tantos outros trabalhadores diante das exigências dos equipamentos de tecnologias avançadas" (SELIGMANN-SILVA 1994, p. 108).

Esta realidade de trabalho é diferentemente percebida por esses trabalhadores. Não só na ótica da preservação individual do bem-estar, longevidade, possibilidades de descobrimento das próprias potencialidades, como também na ótica dos interesses da categoria. Apesar da importância da atividade desenvolvida pelo controlador de tráfego para viabilização e segurança do transporte aéreo, esta não é uma profissão que tenha status e reconhecimento social, segundo relatos colhidos no já referido Relatório de Pesquisa sobre as condições de trabalho e saúde dos controladores de tráfego aéreo, Unesp, 1998.

\subsection{CONDIÇões de Risco PARA A SOCIEDAdE}

Evidentemente, não se pretende, neste estudo, esgotar todas as indagações apresentadas. Busca-se, contudo, trazer para o âmbito da saúde pública a discussão sobre as práticas de saúde destes trabalhadores, enfocadas segundo a dimensão da saúde ambiental e da qualidade de vida nas cidades. Neste sentido, além das condições de risco já esboçadas para a saúde dos trabalhadores da aviação, discutem-se as condições de risco à vida dos passageiros, ao meio ambiente e aos cidadãos que vivem nas grandes cidades. 
Na perspectiva de ampliar a discussão destas questões com a sociedade, cita-se o Painel de Debates realizado na Unesp, em abril de 1999: "Da saúde do controlador de tráfego à qualidade de vida na cidade". Este evento teve por objetivo discutir junto com instituições representativas dos trabalhadores do transporte aéreo e com algumas instituições da sociedade civil, questões do trabalho do controle de tráfego aéreo, buscando debater os riscos desse trabalho que afetam outros setores da sociedade (ANEXO 2). Um dos desdobramentos desse evento foi a publicação de um resumo das discussões e propostas, que exerceu papel relevante para disseminar o debate com os diversos segmentos da sociedade civil envolvidos com a saúde do trabalhador e a saúde ambiental.

Inclui-se como desdobramento desse Painel de Debates a entrevista concedida por esta pesquisadora ao Jornal da USP $\mathrm{n}^{\circ} 484$, de setembro de 1999, que publicou a matéria "Os perigos invisíveis de voar" (ANEXO 3), e nota sobre a entrevista publicada no Informe APVAR n 135 (ANEXO 4).

Dentre os vários aspectos apontados, um é aqui destacado como de relevância pelo técnico responsável pelo projeto de cooperação alemã Gesellschaft fur Techische Zusammenarbeit (GTZ) e pela Companhia de Tecnologia de Saneamento Básico (CETESB), na Mesa Redonda: "O tráfego aéreo e a saúde ambiental no espaço paulistano".

Os dados sobre impactos ambientais gerados às $\operatorname{cidades}^{8}$, a partir de estudos que avaliam a quantidade de poluentes decorrentes das operações de pouso/decolagem (Landing/Take Off) comparados àquela emitida por fontes móveis/veículos (diesel, gasolina, álcool) na Região Metropolitana de São Paulo (RMSP) ${ }^{9}$, mostram que uma aeronave em operação de pouso ou decolagem (LTO) polui o correspondente a 6.578 carros rodando um quilômetro na cidade.

Considerando-se o atual volume de tráfego aéreo,1.600 pousos/ decolagens/ dia na área Terminal São Paulo (Aeroportos de Congonhas, Guarulhos e Marte), calcula-se, segundo estes estudos, que a quantidade de poluentes emitida na atmosfera paulistana

8 Cf. Dados do Instituto Federal de Meio Ambiente da Alemanha, aeroporto de Dusseldorf, 1997. 
equivaleria a 10 milhões de carros rodando $1 \mathrm{Km} /$ dia pela cidade (GTZ/ CETESB 1999).

Ainda como parte desta Mesa Redonda sobre $O$ tráfego aéreo e a saúde ambiental no espaço paulistano, foi apresentado, por um profissional do CEREST-SP, um levantamento bibliográfico sobre estudos que analisam os impactos ambientais do ruído no entorno de aeroportos. Dentre eles, podemos citar:

O incômodo provocado por ruído de aviões versus níveis máximos de ruído. A conclusão deste estudo apontou que a reação ao incômodo foi melhor relatada para o número de aeronaves e o nível de ruído máximo do que a exposição ao ruído equivalente (Leq) (BJORKMAN e col. 1992).

Risco cardiovascular e ruído de tráfego. Neste estudo foram encontradas associações significativas entre ruído e fatores potenciais de risco para doenças isquêmicas do coração. (BABISCH e col. 1993).

Ruído de tráfego e fatores de risco para doenças isquêmicas do coração. $\mathrm{O}$ resultado deste estudo mostrou uma significativa associação entre exposição ao barulho de aeronaves e prevalência de perda auditiva induzida por ruído. Nenhum dos resultados, no entanto, sustenta a hipótese de que o ruído de tráfego aumenta o risco para doenças isquêmicas do coração (BABISCH e col. 1993).

Efeitos de ruído de aviões na capacidade auditiva de crianças em idade escolar. Este resultado mostrou uma associação positiva, mas não significativa, entre exposição ao ruído de avião e risco de perda auditiva (GREEN e col. 1982).

Ruído de tráfego ao redor das escolas: um risco para o desempenho escolar das crianças. Níveis de ruído ao redor de centros educacionais têm afetado negativamente o desempenho de professores e alunos. O resultado foi consistentemente melhor na escola silenciosa (SANS e col. 1993).

Relação de dose-resposta para ruído de tráfego e incômodo. Esta pesquisa mostrou uma correlação mais alta para o nível máximo de ruído. A relação dose-resposta implica que o número de eventos acima de um determinado limite não aumenta a

\footnotetext{
${ }^{9}$ Cf. Dados do Relatório Anual de qualidade do ar nas RMSP, CETESB, 1996
} 
extensão do incômodo: determinado pelo barulho mais alto de um único veículo (RYLANDER e col. 1986).

A associação entre ruído de aviões, perda auditiva e incômodo. O resultado deste estudo indicou que as medidas ambientais não foram um critério apropriado para avaliação de risco de perda auditiva (WU e col. 1995).

Os efeitos psicológicos de um acidente aéreo não fatal para a comunidade. Entrevistas feitas com pessoas envolvidas em acidentes aéreos denotam sintomas como: stress, depressão, traumas. Este estudo sugere que mesmo os acidentes não fatais podem ter graves conseqüências psicológicas para os envolvidos ou mesmo para a comunidade (SLAGLE e col. 1990).

Os níveis de radiação proveniente dos radares são relevantes e devem também ser considerados, conforme recomendações da OIT, porém, não farão parte do presente estudo, por tratar-se de uma questão específica que requer instrumentos definidos (WHO 1993). 


\section{OBJETIVOS DO ESTUDO}

\section{GERAL}

Analisar as representações sociais dos controladores de tráfego aéreo sobre sua saúde e sobre as práticas de saúde preconizadas nas normas de controle e segurança em saúde, do Comando Maior da Aeronáutica, com vistas a obter subsídios que favoreçam a implementação de práticas de promoção e proteção da saúde e segurança da aviação. ESPECÍFICOS

1. Conhecer o cotidiano de vida do controlador de tráfego e suas repercussões sobre a saúde deste trabalhador.

2. Conhecer as condições de trabalho do controlador de tráfego aéreo e identificar o desgaste a que são submetidos no processo de trabalho.

3. Verificar a percepção dos controladores de tráfego aéreo sobre possíveis formas de melhoria da qualidade de vida no trabalho. 


\section{PRÁTICAS E RISCOS À SAÚDE - REFERENCIAIS TEÓRICOS}

\subsection{A SAúde do Trabalhador}

O campo da Saúde do Trabalhador possui como objeto de investigação o processo saúde e doença dos trabalhadores na sua relação com o trabalho. MENDES e DIAS (1991, p. 347) relatam: “apesar das dificuldades teórico-metodológicas enfrentadas, a saúde do trabalhador busca a explicação sobre o adoecer e o morrer das pessoas, dos trabalhadores em particular, através do estudo dos processos de trabalho, de forma articulada com o conjunto de valores, crenças e idéias, as representações sociais, e a possibilidade de consumo de bens e serviços, na 'moderna' civilização urbanoindustrial".

Como campo recente de conhecimentos e práticas, a Saúde do Trabalhador caracteriza-se pela confluência de movimentos sociais e políticos, manifesta-se como um novo projeto de sociedade democrática, marcado pela conquista de direitos de cidadania por meio da livre organização dos trabalhadores.

A teoria da determinação social do processo-saúde doença, cuja centralidade é colocada no trabalho, surge como crítica à limitação dos modelos vigentes da Medicina do Trabalho e da Saúde Ocupacional, o que contribuiu para aumentar os questionamentos à Medicina do Trabalho centrada na figura do médico e orientada pela teoria da unicausalidade: para cada doença um agente etiológico. No âmbito do trabalho, este modelo reflete a propensão de isolar riscos específicos, atuando sobre suas conseqüências, medicalizando em função de sinais e sintomas ou, quando muito, associando-os a uma doença legalmente reconhecida.

Novas políticas sociais foram introduzindo significativas mudanças na legislação do trabalho e, em especial, nos aspectos de saúde e segurança do trabalhador. "A Saúde do Trabalhador é, por natureza, um campo interdisciplinar e multiprofissional, devendo possibilitar não somente um aprofundamento das disciplinas que podem compor o campo, mas também, e principalmente, um diálogo entre as mesmas e os diversos atores 
envolvidos, particularmente os trabalhadores, dentro de uma perspectiva transformadora do conhecimento e da realidade social" (PORTO e FREITAS 1997, p. 60).

$\mathrm{Na}$ Itália, um marco foi estabelecido em 1970, quando o "Estatuto dos Trabalhadores" incorporou princípios fundamentais da agenda do movimento de trabalhadores, tais como: a não delegação da vigilância da saúde ao Estado, a não monetização do risco, a validação do saber dos trabalhadores, a realização de estudos de investigação independentes, o acompanhamento da fiscalização e o melhoramento das condições dos ambientes de trabalho (MENDES e DIAS 1991). O final dos anos 70 foi um período intensamente vivenciado pelo movimento social. Os episódios de Maio de 68 foram importantes referências de solidariedade de classe, de crítica ao poder legitimado na ciência, e com desdobramento nas mais variadas áreas, inclusive na busca dos determinantes dos agravos à saúde da classe trabalhadora nos aspectos infra e supraestruturais da organização da sociedade (ODDONE e col.1986).

No mundo todo, com algumas características próprias de contextos políticosociais distintos, conquistas básicas foram sendo alcançadas pelos trabalhadores norteamericanos (a partir da nova lei de 1970), ingleses (a partir de 1974), suecos (a partir de 1974), franceses (a partir de 1976), noruegueses (a partir de 1977), canadenses (a partir de 1978), entre outros (MENDES e DIAS 1991).

Também na área da saúde surgem propostas para a atenção à saúde de grupos populacionais de trabalhadores, como na Conferência Mundial de Saúde de Alma Ata, em 1978, e na Organização Mundial da Saúde (OMS), nesta mesma época. Em 1983, a Organização Pan-americana da Saúde (OPS) lança o documento "Programa de Acción en la Salud de los Trabajadores" (OPS 1983), com diretrizes para a implantação de programações em saúde na rede pública de serviços voltados para aqueles que trabalham.

$\mathrm{Na}$ mesma direção coloca-se a Organização Internacional do Trabalho (OIT) em sua 71a. Conferência Internacional do Trabalho (1985) adotando a "Convenção e Recomendação sobre os Serviços de Saúde no Trabalho", cujas principais características baseiam-se no princípio da ampla participação dos trabalhadores. Na atuação em equipes multiprofissionais e na implementação de políticas públicas (OIT 1985). Estas 
proposições acompanham uma tendência internacional de ampliação de direitos dos trabalhadores (LACAZ 1997).

No início dos anos 80, surge o modelo da Reforma Sanitária Italiana, que teve como um dos seus pilares a luta pela saúde na fábrica e o controle da nocividade do trabalho, a partir da centralidade de ação dos sindicatos de trabalhadores nos locais de trabalho, usando como metodologia de intervenção o Modelo Operário Italiano (BERLINGUER 1983, 1988).

Este intenso processo social de mudanças tem conseqüências sobre a aparente hegemonia da Medicina do Trabalho e da Saúde Ocupacional. O exercício da participação do trabalhador, em questões de saúde, pôs em xeque conceitos e procedimentos até então consagrados pelo antigo modelo (MENDES e DIAS 1991).

As mudanças que vêm se dando no mundo do trabalho são profundas. "Assim, é cada vez mais difícil falar de um 'mundo do trabalho', que pertence à esfera da fábrica, e de um mundo fora do trabalho. O mundo é um só e os trabalhadores existem neste mundo, transformando e sendo transformados por ele, como um 'modo de viver" (DIAS 1994, p. 257).

Essa dimensão do mundo do trabalho, interna e externa, está intrinsecamente presente na temática do transporte, uma vez que os riscos presentes nas operações do sistema de transporte aéreo ultrapassam o universo do ambiente de trabalho. Coloca-se em questão os riscos à vida. Aponta-se, desta forma, a vulnerabilidade dos trabalhadores, dos passageiros, dos moradores e dos cidadãos em trânsito nas proximidades dos aeroportos.

Assim, no transporte aéreo, esta relação entre trabalho, saúde e meio ambiente tem tripla dimensão: a saúde do trabalhador, a vida dos usuários e a segurança dos cidadãos. Neste sentido, entende-se que os riscos na aviação são relevantes em Saúde Pública, devendo ser abordados no campo do conhecimento referido como "Saúde Ambiental". Parte-se do pressuposto de que o trabalho é um dos determinantes fundamentais da sociedade, e que a sua organização tem reflexos no nível de qualidade de vida de uma população. 
Embora as práticas vigentes de Saúde do Trabalhador estejam ainda fortemente marcadas pela preocupação com a confirmação de nexos causais e com o tratamento de doenças do ou relacionadas ao trabalho, configurando a saúde do trabalhador "como um conjunto de ações de vigilância e assistência (...)", como descrito na recente Norma Operacional de Saúde do trabalhador NOST-SUS, do Ministério da Saúde, em seu Art. $1^{\circ}$, inciso VII, 1998, são inegáveis os princípios acumulados pelas práticas de Saúde do Trabalhador. Estas dizem respeito a categorias de análise-desgaste e medidas de risco (LAURELL e NORIEGA 1989), e ao estudo das condições de trabalho que incorporam a participação do trabalhador na própria concepção exploratória da investigação (BERLINGUER 1983), e ainda ao fato de cada realidade encerrar em si mesma a riqueza e as soluções apropriadas para cada problema (VASCONCELLOS e RIBEIRO 1995).

Neste sentido, o risco decorrente de acidentes no transporte aéreo não é uma questão restrita à saúde do trabalhador. É um problema, como refere ITANI (1996b), que envolve a sociedade contemporânea, já que as ocorrências de risco são freqüentes e envolvem um número cada vez maior de pessoas e situações sociais, apesar das inovações tecnológicas na aviação. A ameaça de eventos catastróficos é preocupante.

O campo da Saúde do Trabalhador dispõe hoje de um considerável acúmulo de experiências de atuação intersetorial, interdisciplinar, com fomento a parcerias e estabelecimento de acordos coletivos, sob a lógica do controle social. Historicamente, no que se refere à inserção política e interinstitucional, a Saúde do Trabalhador tem buscado promover o diálogo entre atores sociais normalmente colocados num segundo plano nas práticas institucionais do país.

Tais princípios coincidem com aqueles que vêm sendo renovados na ótica da Promoção da Saúde, razão pela qual seu instrumental conceitual e metodológico pode ser adotado como estratégia geral de análise e atuação sobre condições sociais que são críticas para melhorar as condições de saúde e a qualidade de vida para os cidadãos e para as cidades (OTTAWA CHARTER 1987). 


\subsection{OS DIVERSOS ASPECTOS DO RISCO}

A bibliografia a respeito do termo "risco" demonstra pouco consenso sobre o seu significado (AYRES 1997). O conceito é utilizado para identificar diferentes situações. A palavra "risco" propicia diferenças de compreensão entre disciplinas do conhecimento e mesmo entre países. O termo refere-se a mensurações de caráter objetivo, como a probabilidade estatística de ocorrência de um determinado evento indesejável e seus efeitos. A palavra risco também expressa situações de caráter subjetivo, a exemplo da percepção e aceitabilidade do risco, condicionadas por fatores socioculturais, socioeconômicos, individuais e psicológicos (SINGLETON 1987).

Nas últimas duas décadas, o uso do termo "risco tecnológico" começou a ser empregado com mais freqüência, justamente em função do aumento do número e da gravidade das situações de risco, causado pela atividade humana. O termo engloba tanto os eventos já ocorridos - acidentes e alterações importantes nas condições de trabalho e de vida, direta ou indiretamente motivados e agravados por fatores de ordem técnica e organizacional, como eventos previsíveis, dadas as possibilidades e circunstâncias que favorecem a sua ocorrência (SEVÁ 1989).

A vivência do trabalhador com condições de risco é diversa. Há riscos de agressão à saúde que se contabilizam cumulativamente no organismo. Alterações dos ritmos biológicos podem ser (co)responsáveis por perturbações do sono, doenças cardiovasculares, alterações do sistema imunológico, disfunções do trato gastrointestinal, aquisição de hábitos de fumo e bebida, e outros distúrbios de origem psíquica. Há riscos que implicam em danos psicossociais, entre eles, o isolamento sóciotemporal conseqüente ao trabalho em horários irregulares, com limitado número de folgas nos fins de semana (FISCHER 1991).

Os trabalhadores em regime de turnos alternados se enquadram em cinco dos 13 critérios propostos para prever conseqüências negativas relacionadas a esta forma de organização do trabalho (JANSEN 1990): falta de regularidade dos horários de trabalho; inconstância na realização de tarefas domésticas e familiares; inconstância de período de repouso à noite; inconstância de períodos de recreação noturnos e inconstância de períodos de recreação nos fins de semana. 
No caso do transporte aéreo, caracterizado por um sistema tecnológico complexo, recoloca-se em questão a convivência com uma controvérsia, já antiga, do risco. Mas o risco em si não é novo. O que é novo é o aumento da dificuldade em reconhecer situações de risco, na medida em que aparentemente todas as situações parecem estar controladas por um aparato arquitetônico de alta tecnologia. A visibilidade de uma condição de risco em sistemas tecnologicamente avançados pode ser mais difícil de ser levantada, em alguns casos quando a própria “inovação" possui também significados controversos para os implicados (ITANI 1996b).

Nos processos tecnológicos de alto risco, entre eles, as usinas nucleares, os complexos petroquímicos e transportes e rotas aéreas, a ocorrência de falhas resulta, invariavelmente, em eventos de caráter catastrófico, expondo a sociedade industrializada a uma condição de fragilidade diante da necessária competência no controle dos riscos. Um acidente gera grande impacto pelo que representa em riscos ou potencialidade de riscos para vidas humanas. Apesar das inovações tecnológicas, as ocorrências são freqüentes e envolvem um número cada vez maior de pessoas.

A condição de risco, numa cultura técnica recente, é construída com significados marcados pela modernidade industrial e apoiada sobretudo em tecnologia nova. Verifica-se que há uma maior expectativa entre os técnicos, especialmente, de que os novos modelos de sistema possuam maiores índices de segurança. Coloca-se a questão: “Até que ponto a segurança é suficiente?" A competência profissional e a mobilização social em torno do risco tecnológico são ainda bastante deficientes em face da urgência e da dimensão das providências necessárias (SEVÁ 1989).

O alto conteúdo de incertezas dos sistemas tecnológicos pode ser potencializado, a depender das condições em que são instalados e das formas de uso. Quando se concebe um equipamento com potencial de risco é preciso testar as probabilidades de falhas e incertezas. Isto pesa na decisão empresarial e freqüentemente obriga a intervenção governamental, via legislação e normas, bem como fiscalizações e sanções. A indústria aeronáutica e a nuclear estão entre as que mais se preocupam com a segurança para reduzir os seus riscos inerentes. No entanto, não há como reduzir a zero a probabilidade de acidente em um sistema tecnológico complexo. A solução possível é reduzir o risco a 
um limite aceitável, de acordo com um critério, para o qual contribuem fatores como viabilidade técnica, custo econômico, aceitabilidade social e benefícios da tecnologia em questão (ROSA 1989)

Teoricamente o risco é inversamente proporcional ao custo da segurança para que o risco se aproxime de zero. No caso do transporte aéreo, no qual as probabilidades de riscos julgadas aceitáveis no funcionamento de um equipamento estão na ordem de uma chance sobre 10 milhões, seria necessário efetuar uma quantidade tão grande de horas de testes, que tornaria impossível sua aplicação. Isto efetivamente inviabilizaria a indústria aeronáutica (ITANI 1998b).

\subsection{AS CONDIÇÕES DE RISCOS À SAÚDE DOS CONTROLADORES DE VÔO}

Os modos de viver e todas as interações humanas são atingidos pelas transformações no mundo do trabalho. Incluem-se, neste caso, desde as formas de produção de bens materiais e de serviços, até as relações humanas nos diferentes âmbitos, do interacional ao comunitário, alcançando os ambientes de trabalho e a família. Os indivíduos e os vínculos afetivos também estão envolvidos neste processo de mudanças profundas (SELIGMANN-SILVA 1997).

ELIAS (1995) destaca a importância das interações entre os processos de transformação técnica e os processos sociais. Os estudos deste pensador contemporâneo foram ressaltados por SELIGMANN-SILVA (1997), com relação à imprevisibilidade das dinâmicas sociais mediadas pelas descobertas científicas e pelas tecnologias incorporadas à indústria, aos transportes, às comunicações, aos serviços em geral e ao cotidiano humano.

Os novos paradigmas da organização do trabalho, marcados pela implantação de novas tecnologias, entre as quais, a automação e a informatização dos processos de trabalho, embora cercados de uma certa aura mítica de se constituírem na última palavra da ciência a serviço do homem, têm introduzido, na verdade, profundas modificações na organização do trabalho.

A “tecnização" repercute na civilização, atingindo de modo especial também os

diferentes territórios e padrões da vida relacional. Convive-se atualmente com o 
acirramento da soberania do capital, que diminui a dependência do trabalhador e, ao mesmo tempo, amplia as possibilidades de controle do trabalho. Configura-se o processo social descivilizatório. Segundo o pensamento de ELIAS (1995), o conjunto das transformações materiais e sociais no mundo do trabalho possibilita encontrar tendências ora civilizatórias ora descivilizatórias. Para este autor, o conceito de "civilização" é tomado como equivalente ao processo social direcionado para o pólo do bem e da vida. O movimento das transformações pode conduzir ao aperfeiçoamento da civilização; quanto aos retrocessos, o autor denomina "descivilização".

Os novos modos de organização do trabalho vêm se traduzindo pela característica da falta de visibilidade da tarefa realizada. Essa questão da invisibilidade torna mais complexa a experiência com as condições de risco. Verificou-se que o operador, em situações de emergência, utilizando-se de suas experiências e conhecimentos acumulados, consegue adaptar os procedimentos previstos ao contexto real de trabalho em situações inesperadas (FAVERGE 1980).

A complexidade dos sistemas é tão grande que os operadores não conseguem compreender os problemas. A concepção e a gestão inapropriadas do ponto de vista da segurança transformam os acidentes em eventos que podem fatalmente ocorrer. $\mathrm{O}$ surgimento de incidentes que não podem ser controlados pelos operadores acaba sendo inevitável (PERROW 1984).

A atividade de controle não deixa dúvidas quanto à importância dos operadores para a confiabilidade do sistema, cuja segurança diz respeito à vida de muitas pessoas (LEPLAT e DE TERSSAC 1991). São eles que tomam as decisões finais que conduzem a uma posição segura diante das perturbações. Alguns estudos referidos a sistemas de transporte coletivo que estão absorvendo novas tecnologias foram realizados no Brasil. Entre eles, podem ser referidas, por exemplo, diferentes pesquisas voltadas para operadores de trem metroviário e de controle de tráfego aéreo (SELIGMANN-SILVA e col. 1986; JARDIM 1994; ITANI 1997; ITANI 1998; VIDAL e MOREIRA 1999).

VIDAL e MOREIRA (1999) comentam a ineficiência relativa dos procedimentos prescritos e a impossibilidade de um domínio técnico perfeito do processo, que levam os operadores a elaborar modos operatórios originais, muitas vezes contraditórios às 
normas prescritas, constituindo, dessa forma, a organização real do trabalho. Assim, o que determina a segurança e eficiência do processo é a capacidade de mobilização das iniciativas individuais diante do inesperado, o que implica a efetividade da dimensão coletiva e a cooperação entre os operadores.

O risco no transporte aéreo tem também uma dimensão ambiental. A partir da década de 70 e durante toda a década de 80, ficou mais explícito o elo entre a Saúde Ambiental moderna e o campo das relações saúde/doença-trabalho dentro do sistema de saúde (CÂMARA e GALVÃO 1995). No Brasil, a Constituição Federal, a lei referente ao Sistema Único de Saúde e algumas leis ordinárias oferecem instrumentos legislativos que têm contribuído de forma ainda incipiente para uma melhor proteção do ambiente em geral e do ambiente de trabalho. Entretanto, as instituições públicas que deveriam coordenar programas nacionais, estaduais e municipais de controle sobre a saúde e o ambiente ainda operam de forma dicotomizada (PORTO e FREITAS 1997).

Para compreender o conjunto das transformações materiais e sociais que envolvem os seres humanos e gera repercussão no ambiente a partir do trabalho, é importante que os problemas ambientais e de saúde do trabalhador sejam vistos integradamente. O fracionamento de um problema complexo em áreas parciais, correspondente ao domínio de disciplinas específicas, impede a análise e proposição de políticas alternativas.

O paradigma da Promoção da Saúde tem como estratégia a prevenção de riscos, a assistência, a informação, a educação e a comunicação, como aspectos fundamentais que vêm ganhando reconhecimento crescente no âmbito dos movimentos de saúde, como uma exigência do contexto atual. A formulação de políticas públicas saudáveis, por meio de uma ação coordenada entre diferentes setores sociais, é essencial para se atingir a qualidade de vida almejada no mundo contemporâneo.

\subsection{OS AGRAVOS À SAÚDE DO CONTROLADOR DE TRÁFEGO AÉREO}

O sistema de turnos rodiziantes faz parte dos fatores psicossociais que interagem nos processos saúde-doença, tendo sido apontado como uma contínua e múltipla fonte de problemas de saúde e de perturbações sócio-familiares. Inúmeras pesquisas 
realizadas, principalmente na Europa, Estados Unidos, Brasil e Japão, mostraram os principais problemas que afetam os trabalhadores sujeitos a esta forma de organização do trabalho (MONK e TEPAS 1985; RUTENFRANZ 1989; CIPOLLA-NETO 1988).

O comprometimento do desempenho é causa do aumento de erros e de acidentes do trabalho durante certos períodos do dia e da noite, sendo ainda maior entre trabalhadores em turnos. Decorrente de uma dessincronização interna do funcionamento do organismo, o desempenho e a disposição para o trabalho ficam prejudicados no período noturno, seja pela incompatibilidade da realização de certas tarefas, seja por conseqüências de perturbações do sono, que levam à impossibilidade de manter a atenção ou mesmo a vigília devido à sonolência (AKERSTEDT 1988).

Os problemas decorrentes das alterações de ritmos biológicos, causados pelo trabalho em turnos e noturno, constituem-se importantes perturbadores da ritmicidade circadiana, tendo certamente implicações negativas em muitos dos processos biológicos de auto-regulação, além de gerarem conflitos de ordem social (LUNA e col. 1997; STOYNEV e MINKOVA 1997; STOYNEV e MINKOVA 1998). Alguns estudos têm apontado, contudo, a diminuição do número de acidentes de trabalho à noite. Entre os aspectos que parecem contribuir para esta ocorrência estão, por exemplo, a redução de atividades laborais perigosas e a menor movimentação de materiais e de pessoal no período noturno (FISCHER 1984). Por outro lado, a ocorrência de grandes acidentes, como de Three Mile Island e Bophal (indústria petroquímica), durante a madrugada, parece ter pouco a ver com o horário do acidente e muito com questões de manutenção e de desconhecimento sobre o desenho do projeto. No entanto, uma ocorrência como a de Chernobyl, sugere que, pelo menos em parte, pode-se associar este evento à necessidade da tomada de decisão administrativa importante em horários desfavoráveis (LLORY 1996), assim como à diminuição da condição de alerta do trabalhador, o que prejudica a tomada de decisões (FOLKARD 1990).

Outro aspecto importante a ser levado em conta no desenvolvimento desse trabalho é a dificuldade de sono - geralmente, um grande problema para os trabalhadores em turnos, em particular para os que trabalham em turnos rodiziantes e ainda acumulam outra atividade. Os vários tipos de perturbações e a diminuição na duração do período 
principal do sono foram estudados (FISCHER e col. 1987). O aumento na sonolência, o aumento dos cochilos ou períodos de sono fragmentados, a diminuição da qualidade do sono e a influência de fatores ambientais, tais como, ruído, desconforto térmico, que perturbam o sono diurno foram estudados por AKERSTEDT (1988). A estrutura do sono diurno é distinta daquela apresentada pelo sono noturno: os episódios do sono paradoxal e do estágio 2 são mais curtos, a latência do sono e a distribuição do sono REM são diferentes nos períodos de sono diurnos (AKERSTEDT e GILLBERG 1982).

SEGA e cols. (1998), pesquisaram, em estudo caso-controle, 80 Controladores de Tráfego Aéreo do Aeroporto de Linate, em Milão. Este estudo procurou esclarecer se os controladores de tráfego apresentavam aumento de pressão sanguínea e hipertensão devido à natureza estressante desta profissão. Os casos foram devidamente monitorados e comparados a um grupo controle, três vezes maior. Segundo os resultados, a pressão sanguínea (sistólica e diastólica) era similar nos dois grupos. Este estudo levantou, ainda, hipóteses que poderiam explicar a semelhança de resultados entre casos e controles. Esta pode estar associada à rigorosa seleção dos controladores e ao preparo adequado destes profissionais para lidar com o estresse que faz parte deste trabalho.

Outros distúrbios, como alterações gastrointestinais, têm sido apontados em alguns estudos (KOLLER 1983). Fatores de risco, tais como o hábito de fumar, dietas mais ricas em carboidratos e lipídios e mais pobres em fibras foram comprovadamente mais acentuadas entre os trabalhadores em turnos. No entanto, há estudos contraditórios no que diz respeito à relação de causalidade entre trabalho em turno e as manifestações de distúrbios gastrointestinais. Alguns autores descrevem, pormenorizadamente, como as alterações biológicas causadas pelas modificações dos padrões de sono podem provocar mudanças na alimentação, na motilidade intestinal e na patogênese da ulceração gástrica e duodenal (VENER 1989).

Em contraposição, outro trabalho, realizado por conceituados cronobiologistas, não encontrou diferença na prevalência de úlcera péptica numa população de milhares de trabalhadores em turnos e diurnos (HALBERG e col. 1977). Não se pode esquecer, como já foi sugerido por muitos autores, que uma auto-seleção pode interferir nos resultados descritos. 
O presente estudo deve observar ainda os efeitos cumulativos, que potencializam a manifestação de distúrbios psicossomáticos, tais como: dor de cabeça, tontura, nervosismo, ansiedade, tremores, fadiga constante, taquicardia, azia, diarréia, perda de apetite, entre outros, freqüentemente acompanhados de distúrbios do sono (RUTENFRANZ 1985).

A influência dos fatores sócio-familiares se expressa nas freqüentes queixas dos trabalhadores em reação aos prejuízos causados por relativo isolamento social, discriminação de atividades e dificuldades em conciliar suas horas de folga com a de seus amigos e familiares. As características individuais e as circunstâncias que cercam a vida dos trabalhadores são muito diversas para serem feitas generalizações, mas pode-se concluir, no momento, que as desvantagens do trabalho em turnos, na esfera social, são maiores que as vantagens (WALKER 1985).

A fadiga visual é citada em trabalhos de ergonomia em postos de trabalho informatizados, onde se apontam fortes exigências visuais associadas ao trabalho intensivo em terminais de vídeo, tendo como conseqüência também a rigidez postural (GUÉRIN e col. 1979).

O aumento considerável do desgaste do aparelho visual é decorrente da introdução de modernas técnicas não somente na indústria, mas no setor serviços. Ainda, existe uma enorme expansão do processo de informação e o aumento do uso do computador, o qual tem transformado inúmeros locais de trabalho em indústria e serviço de manufatura, com o uso do Cathode-ray tube (CRT) screens, video screen, microreaders, e o uso de mesas com iluminação inadequada.

O meio ambiente de leitura sofreu modificações consideráveis. Os caracteres escuros contra um fundo brilhante retransmitem sob condições de luminescência impróprias à adaptação dos olhos à luz. Outros terminais de video, entretanto, possuíam caracteres brilhantes dispostos contra um fundo escuro, que também resultou em problemas. Apesar dos esforços para a adaptação da unidade de display visual (VDU), o trabalho nos terminais de computador sujeita o operador a vários fatores de estresse.

Não há contra-indicações médicas para o trabalho em terminais de vídeo de processos informatizados. No entanto, nenhum operador deve ser solicitado para 
trabalhar mais do que 4 horas por dia nestes postos, assim como, com microscópio ou microleitura. A recomendação é feita para a observação de pausas no decorrer dessas 4 horas. Não existe perigo de exposição à radiação com os equipamentos atuais, desde que estejam regularmente checados. Entretanto, pessoas com problemas de retina ou com dificuldade de acomodação visual devem ser desencorajadas para este trabalho que envolve alto nível de desgaste visual (DANIELLOU e cols 1985). Não se pode compreender os riscos apresentados pelos monitores à saúde, analisando somente os monitores em si. É a situação geral de trabalho que exige do operador.

O estresse psicológico surge em decorrência de condições variadas, como as exigências do trabalho, tensões familiares, preocupações financeiras, entre outras, indo além da capacidade pessoal em lidar com estes desafios. Estas condições variadas, com instabilidade emocional, depressão, falta de concentração, dificuldade de julgamento, queda da imunidade com conseqüências nefastas, podem interferir na operação dos sistemas de controle do tráfego aéreo (DELL'ERBA 1994).

Alguns trabalhos têm indicado o alto nível de exigência de desempenho de memória e capacidade cognitiva destes operadores de tráfego, especialmente nas condições de trabalho que fazem parte da realidade vivida nos tempos atuais, em que a expansão da aviação tem se dado em velocidade maior do que os investimentos na requalificação e ampliação do quadro de recursos humanos (BOUDES 1977; MILLOT 1977).

Esta breve apresentação dos diversos referenciais teóricos é uma tentativa de compreender as mudanças ocorridas no 'mundo do trabalho', os riscos e os agravos a que estão submetidos os controladores. Representam um esforço que desafia o pesquisador na busca da compreensão desse complexo objeto de estudo. Neste sentido, trazer as experiências que são vividas por esses trabalhadores, nesse ambiente com sistemas automatizados, requer uma escolha metodológica que permita apreender o modo como este é realizado, bem como a forma de compreensão de cada um dos gestos de trabalho, por meio das possibilidades que estes operadores possuem de expressar esse entendimento (ITANI 1996a). 


\section{METODOLOGIA}

\subsection{Pesquisa QuAlitativa: JUSTIFICATIVA DA ESCOLHA}

De acordo com os referenciais teóricos, pressupostos, objetivos e complexidade do universo a ser estudado, optou-se por um instrumental de abordagem qualitativa. Para MINAYO (1996), a natureza do problema a ser estudado, bem como o recorte da realidade que cada pesquisa pretende enfocar, devem nortear a escolha metodológica. Similarmente MURPHY e cols. (1998) afirmam que a razão da escolha reside no fato de que este método de pesquisa pode ser uma ferramenta útil para iluminar os fatores que sustentam práticas profissionais que são tidas como não efetivas, inapropriadas ou prejudiciais em cuidados de saúde. Para ANDRÉ (1983) e LEFÉVRE e LEFÉVRE (2000), esta técnica permite apreender o caráter complexo e multidimensional dos fenômenos em sua manifestação natural, sendo que estes aparecem naturalmente nos discursos dos indivíduos, como depoentes e como sujeitos sociais, situados num dado campo social.

O espaço denominado campo social leva ao entendimento de que as pessoas envolvidas nesta pesquisa mostram-se como um conjunto de indivíduos, que, situados numa dada posição social, podem ser reconhecidas como uma categoria. Estes sujeitos detêm hábitus e representações semelhantes, que se traduzem em determinadas práticas sociais e modalidades de discursos que as expressam (BOURDIEU 1990).

Os sujeitos envolvidos fornecem, na mediação discursiva, as representações sociais. Segundo JODELET (1989), dentre as mais importantes funções das representações sociais, está a de "ancorar" os eventos da vida cotidiana em discursos, justificativas e teorias que dão sentido à vida dos indivíduos que os vivenciam. Por meio das representações sociais pode-se, então, compreender os sujeitos como representantes de um coletivo, uma vez que o depoimento de um indivíduo, como sujeito social, expressa o discurso de muitos. Em síntese, pode-se dizer que a abordagem qualitativa permite reconstruir as representações sociais que constituem a vivência das relações objetivas pelos atores sociais que the atribuem significados (MINAYO 1996). 
Grande parte das pesquisas qualitativas adota a análise de discurso ou mais precisamente a análise temática de discurso, que permitem que os indivíduos expressem seu pensar por meio de depoimentos. Tradicionalmente, a forma de análise utilizada a partir das expressões que retratam os depoimentos é o estabelecimento de categorias. A categoria, desta forma, torna os depoimentos e demais discursos equivalentes, porque expressam a mesma idéia. A categorização propõe o agrupamento de discursos através da eliminação da variabilidade individual não pertinente ao fenômeno pesquisado, sendo, pois, classificatória. A categoria é, assim, condição para a 'cientificidade', na medida em que os discursos - e os indivíduos que os professam são classificados, isto é, reduzidos ou equalizados nas classes, podendo então ser distribuídos por estas classes (LEFÉVRE e LEFÉVRE 2000).

Na proposta do Discurso do Sujeito Coletivo (DSC), os discursos não se anulam ou se reduzem a uma categoria comum unificadora, já que o que se busca fazer é precisamente o inverso, ou seja, reconstruir, com pedaços de discursos individuais, como em um quebra-cabeça, tantos discursos-síntese quantos se julguem necessários para expressar uma dada 'figura', ou seja, um dado pensar ou uma dada representação social sobre um fenômeno (LEFÈVRE e LEFÈVRE 2000).

O DSC apresenta-se como uma estratégia metodológica mais adequada para operar o resgate de uma dada representação social, assim como o conjunto das representações que conformam um dado universo imaginário. Este universo imaginário está contido no campo social que está sendo pesquisado. No decorrer dos passos metodológicos, as representações sociais aparecem sob a forma de um discurso vivo e direto. É o modo como os indivíduos reais pensam (LEFÉVRE e LEFÉVRE 2000).

Neste processo, torna-se fundamental relacionar os dados bibliográficos e problemas oriundos da observação do campo, a fim de verificar-se como este todo se estrutura e se relaciona. Esta constituição só é possível quando se parte de um processo em que conceitos interagem entre si e com a totalidade. É importante salientar que a análise não se constitui apenas em um estágio final de investigação. Esta opção metodológica deve estar presente desde o início do projeto, quando se verifica a 
pertinência das questões selecionadas diante das características da situação em estudo. Torna-se, entretanto, mais sistemática e mais formal após o final da coleta de dados.

Nesta perspectiva, as informações obtidas são submetidas à triangulação, técnica considerada fundamental para verificar a propriedade das interpretações fundadas em dados qualitativos. A triangulação, como estratégia metodológica, parte da constatação de que as ações sociais e as falas dos atores devem ser contextualizadas. A aferição dos dados não é realizada por meio de avaliação de índices, ao contrário, trata-se de uma análise das relações de contexto com as ações. A utilização de multimeios, própria da proposta de triangulação, garante maior validade dos dados, permitindo que seus problemas e limitações sejam compensados pelo uso de outros métodos (ADORNO e CASTRO 1994).

A presente pesquisa delimita-se em conformidade com o referencial teórico e metodológico adotado. O campo social escolhido para o desenvolvimento da pesquisa foi o Controle de Aproximação de São Paulo (APP-SP), localizado no Aeroporto de Congonhas. Os controladores de tráfego aéreo são os sujeitos sociais desta pesquisa, sendo os responsáveis pelo trabalho realizado no controle de aproximação e decolagem das aeronaves na Terminal São Paulo.

\subsection{Pesquisa EXPLORATóRIa}

Destaca-se que anteriormente a esta pesquisa, foi realizado, com a participação desta pesquisadora, um acompanhamento do trabalho dos controladores de tráfego aéreo, num período de observação prévia, durante um ano, como parte do Projeto Condições de Saúde e Trabalho dos Controladores de Tráfego Aéreo, 1998. Este contato prévio com o campo possibilitou o conhecimento de pontos importantes e significativos, facilitando a compreensão do universo onde se dá a produção dos serviços

de transporte. Esta etapa prévia contribuiu para a definição dos objetivos deste estudo e na elaboração do instrumento de pesquisa definitivo.

De acordo com PIOVESAN e TEMPORINI (1996), a pesquisa exploratória define-se na qualidade de parte integrante da pesquisa principal, com a finalidade de melhor adequar o instrumento de medida à realidade que se pretende conhecer. Ainda, 
segundo os autores, a finalidade primordial da pesquisa exploratória é buscar o conhecimento do repertório popular de respostas, e este pode se referir ao conhecimento, crença e opinião, como à atitude, aos valores e à conduta.

\subsection{O SUJEITO SOCIAL DA PESQUISA}

Para BORDIEU (1990), citado por MINAYO (1996 p. 110), sobre a representatividade da fala de um indivíduo, um dado discurso pode estar representando a fala de um sujeito social, pois a identidade de condições de existência tende a reproduzir sistemas de disposição semelhantes, através de uma harmonização objetiva de práticas e obras. Neste sentido, SIMIONI (1996), também a partir das posições de BORDIEU, observa que o sujeito social da pesquisa ocupa posição específica no campo; estando em condições objetivas semelhantes, tende a reproduzir um sistema de disposição também semelhante, podendo-se portanto, universalizar a fala desses indivíduos, como sujeitos sociais.

Os sujeitos sociais desta pesquisa foram 12 indivíduos, representados por civis e militares, homens e mulheres. Uma questão considerada chave para este estudo foi a investigação sobre a atividade secundária, na perspectiva de conhecer o cotidiano de vida deste trabalhador e as repercussões a sua saúde.

Os sujeitos desta pesquisa pertenciam na época da coleta de dados, ao quadro efetivo do APP-SP, à Torre de Congonhas e à Torre de Guarulhos. Suas atividades e exigências de desempenho eram parecidas, o que os expunha a condições de risco semelhantes. Entre os entrevistados, constatou-se o fato de haver o fato de haver na trajetória profissional do controlador, passagens pelo Centro de Controle de Tráfego (ACC), Centro de Controle de Aproximação (APP) e Torre de Controle (TWR).

Procurou-se garantir, nas entrevistas, a maior diversidade possível em relação ao tempo na função, uma vez que existe uma diferença significativa na relação com o trabalho do controlador mais antigo e mais novo, provavelmente, em virtude das deficiências no processo de formação que vem se deteriorando com o passar dos anos. 


\subsection{ELABORAÇÃO DO INSTRUMENTO DE PESQUISA}

O discurso dos diferentes depoentes foi colhido por meio de Roteiro de Entrevistas (ANEXO 5), que sofreu algumas modificações, em decorrência do pré-teste. Este foi realizado em meados de novembro, com quatro entrevistados, e orientou os assuntos de interesse para a pesquisa. O fato de esta pesquisadora ter participado do campo, na pesquisa sobre condições de trabalho e saúde do controlador de tráfego aéreo (1998), facilitou sobremaneira o processo de aproximação para a realização deste estudo. Ainda, os contatos institucionais estabelecidos anteriormente pela Unesp, com o Comando Maior da Aeronáutica para realização daquele Projeto de Pesquisa, facilitaram o acesso à direção do Serviço Regional de Proteção ao Vôo de São Paulo e ao APP-SP. A partir de julho de 1999, após a realização do Painel de Debates: Da Saúde do Controlador de Tráfego Aéreo à Qualidade de Vida na Cidade, o presente estudo começou a ser desenvolvido. A chefia do APP-SP mostrou-se sensibilizada com a proposta do presente estudo ao autorizar a realização das entrevistas, as observações do campo e o levantamento de dados e informações necessários à conclusão desta investigação.

\subsection{LOCAL DE COLETA DE DAdos}

A partir de contatos iniciados com alguns controladores à época da realização da pesquisa sobre as Condições de Trabalho e Saúde do Controlador de Tráfego Aéreo (1998), outros foram sendo estabelecidos para este estudo. Algumas entrevistas foram realizadas na residência do entrevistado, outras, no próprio ambiente de trabalho. No entanto, de acordo com a preferência do controlador, a maioria dos depoimentos foi tomada no local de trabalho. O retorno ao campo possibilitou à pesquisadora rever alguns pontos e situações de interesse para melhor compreensão do objeto de estudo.

\subsection{TERMo de CONSENTIMENTO dos SuJEITOS}

Todos os entrevistados foram abordados mediante uma mesma estratégia, em que se delineava a proposta da pesquisa e a relevância do tema para a saúde pública. Nesta oportunidade, apresentava-se ao sujeito uma cópia do Projeto de Qualificação e do 
Formulário do Ministério da Saúde para a realização da pesquisa envolvendo seres humanos, autorizada pela chefia do APP-SP. Em seguida, o sujeito da pesquisa era convidado a assinar o Termo de Consentimento (ANEXO 6), sendo devidamente esclarecido sobre a regulamentação do Conselho Nacional de Saúde e da Comissão Nacional de Ética em Pesquisa. De acordo com a resolução n ${ }^{\circ} 196 / 96$, os sujeitos envolvidos em pesquisa têm a garantia de sigilo sobre as informações prestadas, anonimato e independência em relação à hierarquia da instituição, sendo garantido, ainda, o direito de desistência ao participante em qualquer fase da pesquisa.

\subsection{Instrumento de Coleta de Dados}

Os sujeitos normalmente apresentavam-se à vontade e interessados em participar da pesquisa, sendo que em momento algum houve recusa dos participantes. O transcorrer desta etapa foi bastante tranquilo, tendo sido realizado entre dezembro de 1999 e janeiro de 2000. As entrevistas foram gravadas em fita K7 de sessenta minutos e variaram quanto a sua duração, de 50 minutos a 2 horas. Registra-se a utilização de um diário de campo, onde informações relevantes eram anotadas, quase sempre logo após o termino da entrevista. Todos os participantes concordaram em colocar o microfone na lapela, sendo observado também como um ponto importante o fato de os sujeitos apresentarem-se abertos a um contato olho a olho com a pesquisadora. Observou-se que os participantes, de maneira geral, mostraram-se muito lúcidos, quanto ao entendimento da pergunta e clareza das respostas. O instrumento de coleta foi pré-testado com representantes da mesma população. Os depoimentos foram literalmente transcritos. A transcrição foi processada para um microcomputador, utilizando-se a linguagem Word/Windows 98, e seu conteúdo foi trabalhado, usando-se recursos deste mesmo editor de texto.

Os dados objetivos foram coletados na primeira parte da entrevista. Referiam-se à idade, sexo, escolaridade, procedência, vínculo institucional (militar ou civil), estado civil, tempo na função do controle, atividade secundária, tempo na atividade secundária e salário no controle de tráfego aéreo. 
De acordo com o roteiro de entrevista, alguns temas foram se constituindo naturalmente com base na análise inicial dos depoimentos. Esse processo de interpretação e tematização foi feito com base na técnica de análise temática de discurso, segundo a metodologia do DSC (SIMIONI 1996; LEFÉVRE e LEFÉVRE 2000). Foram utilizadas três figuras metodológicas, a saber: a Idéia Central, as Expressões-chave e o

\section{Discurso do Sujeito Coletivo.}

\subsection{Técnica de ANÁlise de Dados}

A Idéia central para efeito de análise dos depoimentos poderia ser entendida como a síntese do conteúdo discursivo explicitado pelos sujeitos. São as afirmações, negações e dúvidas a respeito da realidade factual, bem como os juízos de valor a respeito da realidade institucional ou do contexto social em que os sujeitos estão envolvidos.

As expressões-chave (EC) são trechos selecionados dos discursos, que ilustram as idéias centrais. Busca-se aqui o resgate da literalidade do depoimento. Este resgate é fundamental, na medida em que, através dele, o leitor é capaz de julgar a pertinência ou não da forma encontrada para traduzir discursivamente a idéia central comparando um trecho selecionado de depoimento com as afirmativas reconstruídas. Ou seja, as expressões-chave são uma espécie de "prova discursivo-empírica" da "verdade" das idéias centrais.

O discurso do sujeito coletivo (DSC) é uma estratégia metodológica com vistas a tornar mais clara uma dada representação social; é uma forma discursiva de apresentação e de tratamento dos depoimentos, que compõe o substrato de uma representação social.

Desta forma, o DSC consiste na reunião, num só discurso-síntese, de vários discursos individuais emitidos como resposta a uma mesma questão de pesquisa, por sujeitos social e institucionalmente equivalentes ou que fazem parte de uma mesma cultura organizacional e de um grupo social homogêneo, uma vez que os indivíduos que fazem parte deste grupo ocupam a mesma ou posições vizinhas num dado campo social. 
O DSC é, então, uma forma de expressar diretamente a representação social de um dado sujeito social.

Por meio deste instrumento discursivo, é possível visualizar melhor a representação social, na medida em que ela aparece não sob uma forma (artificial) de quadros e tabelas de categorias, mas sob uma forma (mais viva e direta) de um discurso, que é o modo como os indivíduos reais, concretos, pensam.

Para a elaboração do DSC parte-se dos discursos em estado bruto, que são submetidos a um trabalho analítico inicial de decomposição, que consiste, basicamente, na seleção dos principais temas e idéias presentes em cada um dos discursos individuais e em todos eles reunidos, e que termina sob uma forma sintética, em que se busca a reconstituição discursiva da representação social

Nesse sentido, é fácil verificar que o DSC é, no fundo, um expediente de apresentação de resultados de pesquisa qualitativa, que não difere de algumas formas classicamente encontradas em pesquisas quantitativas, para dar visibilidade aos dados "frios".

O DSC implica, pois, num processo dialético, que parte de uma síntese inicial, para se reconstituir, no final, como uma nova síntese de pensamento de um sujeito coletivo de natureza social.

O sujeito social que emana do DSC é discursivamente equivalente ao sujeito individual, portador e emissor de um discurso concreto, atestado; é equivalente, ainda que não idêntico, uma vez que o sujeito discursivo coletivo também é passível de ser visto como portador de um dado discurso, ainda que não exista concretamente como emissor deste discurso, porque se trata de um sujeito abstrato, reconstruído.

O DSC pode conter contradições internas que, neste caso, estão refletindo as tensões dialéticas internas ao setor do campo. O conteúdo do DSC é composto por aquilo que um dado sujeito individual falou e também por aquilo que poderia ter falado, e que seu "companheiro de coletividade" atualizou "por ele", já que o DSC é a expressão concreta do imaginário do campo a que ambos pertencem e da posição que ocupam dentro deste campo. Em síntese, o DSC é como se o discurso de todos fosse o discurso de um. 
Os autores do modelo instrumental proposto (SIMIONI 1996; LEFÉVRE e LEFÉVRE 2000), enfatizam que em termos metodológicos, o processo da construção do DSC deve ser transparente, aparecendo sempre que possível, ao lado dos discursos individuais dos sujeitos, com vistas a que a necessária arbitrariedade presente na sua construção possa ser avaliada e, se for o caso, refutada pelo leitor.

Uma outra forma de teste de plausibilidade do DSC consiste na sua apresentação (ou re-apresentação) para alguma instância que represente o coletivo dos indivíduos de onde foi extraído, a fim de que, através desta instância, o dito coletivo possa verbalizar se sente aquele discurso como sendo representativo de seu universo de pertencimento.

Os Discursos dos Sujeitos Coletivos são confeccionados com base em trechos selecionados literalmente dos depoimentos individuais, aos quais é possível acrescentar pequenos artefatos (como a presença de conectivos entre parágrafos, a correção de alguns erros ortográficos grosseiros, etc.), apenas para efeitos didáticos (LEFÈVRE e LEFÉVRE 2000).

\subsection{ANÁLISE DOS DEPOIMENTOS}

\section{1a etapa}

Com vistas ao resgate das representações sociais dos sujeitos em particular para cada uma das questões propostas no roteiro de entrevista, utilizou-se o Instrumento de Análise de Discurso 1 (IAD1). Este instrumento descreve as idéias centrais que cada um dos indivíduos apresentam em seus discursos e as expressões-chave para cada resposta de uma dada pergunta da entrevista (ANEXO 7).

\section{2a etapa}

Nesta etapa, listaram-se no Instrumento de Análise de Discurso 2 (IAD2), todas as idéias centrais e todas as expressões-chave para cada um dos sujeitos, relativas às mesmas respostas de uma dada pergunta da entrevista, buscando assim o total resgate da literalidade dos sujeitos em questão (ANEXO 8).

3a etapa

O passo seguinte foi desenvolvido por meio do Instrumento de Análise de Discurso 3 (IAD3), constituindo-se no discurso síntese, ou seja, o Discurso do Sujeito 
Coletivo (DSC). Este consiste na transformação e redução da listagem de várias idéias centrais e de várias expressões-chave numa só, num discurso encadeado, como se houvesse apenas um indivíduo falando. Este sujeito seria o portador de um discursosíntese de todos os indivíduos que compõem um dado sujeito coletivo. Esta etapa, pertencente ao IAD 3, é apresentada e discutida no próximo capítulo, por ser a fase principal e conclusiva do método.

Apresenta-se o Quadro Síntese, em que se pôde verifica a consonância entre os objetivos desta pesquisa e os aspectos analisados. Neste sentido, por meio da metodologia do DSC, puderam-se enunciar os temas relativos às representações sociais dos controladores de tráfego aéreo sobre sua saúde e sobre as práticas de saúde adotadas pelo Sistema de Saúde da Aeronáutica.

Para a construção do Quadro Síntese, num primeiro momento, recorreu-se à categorização dos discursos dos sujeitos em temas que apareciam repetidamente na fala dos controladores.

Num segundo momento, utilizando-se as categorizações e expressões-chave, foram identificadas as idéias centrais que cada sujeito apresentou em seu discurso.

Num terceiro momento, com base nas idéias centrais listadas e devidamente embasadas no discurso literal dos sujeitos, construiu-se o DSC. Com a finalidade de facilitar a compreensão do leitor, são apresentados, no próximo capítulo, os DSCs mais relevantes e significativos à consecução dos objetivos deste estudo.

Os temas aparecem ilustrados em cores diferentes, com a finalidade de orientar o entendimento do leitor no decorrer da pesquisa. 


\section{RESULTADOS E DISCUSSÃo}

Os resultados desta pesquisa são apresentados em duas partes. Na primeira, é caracterizado o sujeito social da pesquisa, e na segunda, apresentado o Quadro Síntese que sistematiza as representações sociais dos controladores de tráfego aéreo sobre os temas:

- o trabalho no controle de vôo;

- a experiência com o risco no cotidiano do trabalho;

- as práticas de saúde dos controladores de tráfego aéreo;

- as relações do controlador com a hierarquia militar e

- os rumos possíveis na realidade de trabalho no controle de tráfego aéreo.

O Quadro Síntese foi construído com a finalidade de permitir ao leitor a apresentação da totalidade dos DSCs. Através deste, torna-se possível visualizar a complexidade que caracteriza o conteúdo e a forma das representações sociais que, reunidas, formam o universo imaginário disponível sobre a temática desta pesquisa. $\mathrm{O}$ uso de cores diferentes no Quadro Síntese tem por objetivo orientar o leitor, conferindo destaque aos temas.

A seleção dos cinco temas levou em consideração os objetivos da pesquisa e contemplou as falas mais significativas, tanto as consensuais como as contraditórias, que estiveram presentes em cada depoimento. Metodologicamente, estes temas foram categorizados com base nas cinco questões selecionadas do roteiro de entrevista.

Os Discursos do Sujeito Coletivo relativos a estes temas são, desta forma, apresentados na íntegra. Segundo LEFÈVRE e SIMIONI (1998), a interpretação dos depoimentos é a chave de uma relação precisa entre um conjunto de discursos adequadamente re-organizados, por um detalhado esforço analítico e um referencial teórico que respalda a temática em estudo.

$\mathrm{Na}$ perspectiva de vencer o desafio para melhor compreensão deste trabalho, propõe-se que os Resultados e a Discussão sejam mostrados em seqüência e no mesmo capítulo. Justifica-se que esta forma de apresentação, além de facilitar a compreensão do 
leitor, permitir-lhe-á julgar a pertinência da categorização. Contribuirá também para impedir o distanciamento entre a totalidade do DSC e a sua análise, evitando a fragmentação do discurso e a conseqüente perda de conteúdo, e sobretudo eliminando a dicotomia do discurso no momento da discussão.

\section{O sujeito social da pesquisa}

Os sujeitos sociais desta pesquisa foram 12 indivíduos, sendo 8 do sexo masculino e 4 do sexo feminino. Dos 12 entrevistados, 6 são civis e 6 são militares. Procurou-se manter uma distribuição equilibrada destas variáveis, considerando que a realidade de trabalho de militares e civis é diversa.

Os sujeitos desta pesquisa são descritos de forma sigilosa, procurando, dentro de critérios éticos, garantir a não identificação dos entrevistados, conforme preconiza a resolução 196/96. Desta forma, definiu-se o "controlador coletivo" como um profissional altamente qualificado, sendo que $80 \%$ dos pesquisados têm nível superior completo. A média de idade dos sujeitos de estudo é de 39 anos. Os controladores entrevistados, em sua maioria (73\%), são casados. O local de procedência prevalente é a cidade de São Paulo, sendo que apenas $27 \%$ são de outros estados. O tempo na função variou e 3 a 26 anos. Confirmou-se que 90,1\% dos controladores têm uma função secundária, sendo em sua maioria professores.

\section{O enfoque metodológico: o Discurso do Sujeito Coletivo e a Análise Ergonômica do}

\section{Trabalho}

Trabalhos de pesquisa na área de saúde do trabalhador de tráfego aéreo são pouco encontrados no Brasil, Observa-se, contudo, no cenário internacional, que esta é uma atividade extremamente pesquisada, e muitas referências científicas podem ser encontradas. No entanto, a existência de realidades tão diferenciadas em termos de valorização profissional, de aspectos da organização administrativa, notadamente relativos à hierarquia militar, dificulta a análise e inviabiliza a comparação de resultados.

Neste sentido, o acesso aos Relatórios de Pesquisas Ergonômicas Realizadas no Controle de Tráfego Aéreo do Rio de Janeiro (App/RJ), em 1999, (VIDAL e MOREIRA 1999), foi de extrema importância para a consecução deste trabalho. Torna-se 
necessário, entretanto, registrar as diferenças de enfoque metodológico do presente estudo.

$\mathrm{Na}$ metodologia do Discurso do Sujeito Coletivo trabalha-se com as representações sociais expressas pelas falas dos trabalhadores que traduzem suas vivências cotidianas. Alguns autores têm utilizado esta metodologia para analisar diferentes realidades em seus estudos (CASTRO SÁ 1998; BERNARDINO 1998; BERTOTTO 1999; TEIXEIRA 1999; CARRARO 1999; MOREIRA NETO 1999). Por meio dos discursos confirmam-se ou negam-se as hipóteses iniciais sobre o objeto em questão.

Tendo em vista que o objetivo desta pesquisa era verificar a percepção dos controladores de tráfego aéreo sobre a presença de estressores, sobre os sofrimentos ou as satisfações resultantes do trabalho, seus relatos foram valiosos para o entendimento do processo saúde-doença no trabalho.

A ergonomia, por seu lado, trabalha com fatos reais, já que se parte de observações sistemáticas, de entrevistas, para que sejam avaliadas as reais condições de trabalho e conseqüências resultantes à saúde e ao desempenho no trabalho, entre outros. Na Análise Ergonômica do Trabalho - AET (ROHMERT e LANDAU 1983), comparam-se as atividades prescritas e reais, que são observadas sob a ótica do pesquisador e dos trabalhadores. Após estas etapas realiza-se uma confrontação entre estes dois "olhares" para validá-los.

Neste sentido, apesar das diferenças de enfoque metodológico entre a metodologia do Discurso do Sujeito Coletivo e a Análise Ergonômica do Trabalho, os Relatórios de pesquisas ergonômicas realizadas no Controle de Tráfego Aéreo (VIDAL e MOREIRA 1999), constituiu importante referencial para o desenvolvimento deste estudo, permitindo a triangulação, ou seja, a utilização de diferentes meios para verificar a propriedade das interpretações fundadas em dados qualitativos (ADORNO e CASTRO 1994). A análise dos dados e resultados do presente estudo pôde, dessa forma, ser confrontada com uma situação de trabalho vivida no controle de tráfego aéreo do Rio de Janeiro, cuja realidade mostrou-se semelhante à existente neste mesmo setor, em São Paulo. 


\section{QUADRO SÍNTESE}

Representações sociais tematizadas no DSC dos controladores de tráfego aéreo.

\section{O trabalho no Controle de Tráfego AÉreo}

- O trabalho.

- A tecnologia.

- A jornada de trabalho.

- O trabalho de equipe.

\section{A EXPERIÊNCIA COM O RISCO NO COTIDIANO DO TRABALHO DO CONTROLE DE} TrÁfego AÉreo

- O risco cotidiano.

- A produção da consciência culposa.

- Os riscos para a sociedade.

\section{AS PRÁTICAS DE SaÚde Do CONTROLAdor De TrÁfEgo AÉreo}

- O conhecimento da realidade de trabalho.

- O acompanhamento psicológico

- Os riscos e os agravos à saúde.

\section{AS RELAÇÕES DO CONTROLADOR DE TRÁFEGO AÉREO COM A HIERARQUIA} MILITAR

- O militar.

- O civil.

\section{RuMOS POSSÍVEIS NA REALIDADE DE TRABALHO DO CONTROLE DE TRÁFEGO}

$$
\text { AÉREO }
$$

- A aeronáutica e o Controle de Tráfego Aéreo.

- As relações de poder no controle de tráfego aéreo.

- A privatização do controle de tráfego aéreo.

- O controle do risco. 
O TRABALHO NO CONTROLE DE TRÁFEGO AÉREO.

\begin{tabular}{|c|c|c|}
\hline \multicolumn{3}{|c|}{ O TRABALHO NO CONTROLE DE TRÁFEGO AÉREO. } \\
\hline IDÉIA CENTRAL & EXPRESSÕES-CHAVE & DisCuRSO do SUJEITo COLETIVO \\
\hline O trabalho é fantástico & $\begin{array}{l}\text { O trabalho.exige atenção total. É } \\
\text { uma profissão fascinante. A } \\
\text { paixão pelo controle de tráfego se } \\
\text { revela como um prazer imenso } \\
\text { pelo serviço. }\end{array}$ & $\begin{array}{l}\text { É uma atividade encantadora... você trabalha com pessoas, você está } \\
\text { sempre se comunicando. Sua função primordial é cuidar da integridade } \\
\text { física de muitos e isso é gratificante, mas quando você consegue resolver } \\
\text { todos os problemas que surgem em momentos inesperados, é muito } \\
\text { estressante. É um dos poucos trabalhos que você não tem que trazer nada } \\
\text { para casa. Quando termina é um alívio. Trabalhar naquilo que se gosta é } \\
\text { um dom de Deus, é um prêmio, é uma realização, é uma fonte de prazer. } \\
\text { A emoção que traz o trabalho com fluxo de tráfego grande é fantástica... } \\
\text { Você está ali ligado, esquece de tudo, dá um bloqueio de toda a tua vida. } \\
\text { Por um período você mantém atenção total, mas em função do volume } \\
\text { de tráfego e do estresse, em determinado momento você sofre um } \\
\text { bloqueio mental. Você está ali, como se você jogasse um video game. } \\
\text { Você é parte daquilo, é um momento de ficção. É fascinante mas não são } \\
\text { todos que se adaptam obviamente... Eu adoro o que faço. É aquele } \\
\text { negócio. Se existe amor à primeira vista... comigo foi nisso aqui. Se eu } \\
\text { saísse daqui, ainda hoje, apesar de tudo, eu ia me sentir tipo uma viúva, } \\
\text { que perdeu um grande amor. Sinto um prazer imenso nesse serviço, } \\
\text { levanto venho legal pra cá... não tenho o menor problema, se eu pudesse } \\
\text { ficaria cinqüenta anos... pelo serviço. O ambiente aqui me faz muito } \\
\text { bem. Também sempre saio bem daqui... me esqueço de tudo lá fora } \\
\text { enquanto trabalho aqui... e para mim é sempre um prazer. Ajudar.... um } \\
\text { avião perdido, você se sente bem com isso. Então, é claro, quando dá } \\
\text { alguma coisa errada eu fico triste, chateado, agoniado... mas na maioria } \\
\text { das vezes, no geral, no balanço que eu faço é que sempre é muito } \\
\text { prazeroso... muito bom para mim. }\end{array}$ \\
\hline
\end{tabular}


A busca do prazer no trabalho e a fuga do desprazer constituem desejo permanente do trabalhador. Contata-se que, em face das exigências contidas na organização do trabalho, muitas vezes, o sofrimento psíquico faz do trabalho apenas uma necessidade "imposta" de sobrevivência. No entanto, fica visível no DSC dos controladores que a grande maioria gosta muito do que faz, e a atividade no controle é motivo de um grande prazer. Isso é dito e repetido pelos trabalhadores de diferentes modos, em diferentes ocasiões.

A compreensão da Representação Social sobre o Trabalho Fantástico torna-se uma questão importante para o pesquisador.

"A emoção que traz o trabalho com fluxo de tráfego grande é fantástica... Você está ali ligado, esquece de tudo, dá um bloqueio de toda a tua vida."

Esta percepção coletiva sobre a atividade realizada pode tornar-se chave no sentido de estimular o prazer no trabalho, embora seja uma questão ambígua para o controlador.

"Por um periodo você mantém atenção total, mas em função do volume de tráfego e do estresse em determinado momento, você sofre um bloqueio mental"

Por outro lado, esta responsabilidade é referida como gratificante. Sentir-se responsável por vidas humanas parece ser extremamente custoso e gerador de ansiedade e estresse.

"O controle de tráfego é uma atividade encantadora... Sua função primordial é cuidar da integridade fisica de muitos... e isso é gratificante, mas quando você não consegue resolver todos os problemas que surgem em momentos inesperados, é muito estressante."

Estudos realizados por MARSTEDT (1994) descrevem distúrbios psicológicos e relacionais em áreas automatizadas. O pesquisador analisa os aspectos organizacionais existentes em empresas alemãs e identifica conceitos e práticas de racionalização que são responsáveis pelo aumento das cargas mentais de trabalho, condicionando riscos para a saúde. Observa-se que tais sobrecargas diriam respeito principalmente à complexidade das atividades, à exigência de polivalência, a elevadíssimas cargas 
psicoafetivas, tais como: autocontrole emocional exacerbado, exigência de perfeição no desempenho, alto nível de responsabilidade, insegurança quanto às perspectivas de carreira, a múltiplos tipos de pressão temporal (escalas, ritmos), e outros.

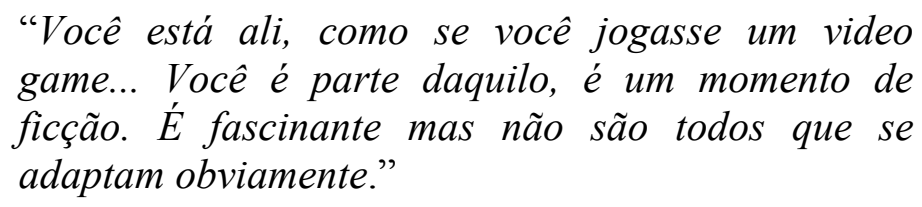

Os DSCs apontam indícios de que a imagem ou representação que os controladores têm da própria profissão é de serem pessoas especiais, que têm sob seu controle a ponta de linha de todo o sistema. Sentem-se cheios de poder, até mais que o próprio piloto. São considerados pelos seus superiores como temperamentais e cheios de superioridade... apesar de desempenharem seu trabalho em sistemas de alta complexidade, quase sempre questionam o mito da confiabilidade absoluta e apontam com clareza as falhas e problemas deste sistema. O "prazer pelo trabalho" manifestado no discurso pode ser visto como uma estratégia defensiva, um fator que mascara o medo do trabalhador. A representação mental de "domínio do sistema”, neste sentido, poderia ser entendida como uma elaboração de defesa psíquica específicas (DEJOURS 1992). 
O TRABALHO NO CONTROLE DE TRÁFEGO AÉREO.

\begin{tabular}{|c|c|c|}
\hline \multicolumn{3}{|c|}{ O TRABALHO NO CONTROLE DE TRÁFEGO AÉREO. } \\
\hline IDÉIA CENTRAL & EXPRESSÕES-CHAVE & DisCuRSO do SuJEITo COLETIVO \\
\hline $\begin{array}{l}\text { Existe uma falsa } \\
\text { modernidade em um } \\
\text { sistema tecnológica- } \\
\text { mente desatualizado. }\end{array}$ & $\begin{array}{l}\text { Apesar do aparente avanço } \\
\text { tecnológico, há falta de } \\
\text { confiabilidade no sistema. O } \\
\text { novo sistema implantado já está } \\
\text { degradado. Eu tenho dificuldades } \\
\text { enormes de acesso à informação. }\end{array}$ & $\begin{array}{l}\text { Com relação aos equipamentos e às condições de trabalho, o sistema } \\
\text { antigo funcionava num ambiente escuro que a gente chamava de "bate } \\
\text { caverna". Trabalhar no escuro descansava mais. Quando mudaram os } \\
\text { equipamentos, a impressão que se teve é que era um "doente terminal } \\
\text { com vestido novo", porque mudaram as telas, o visual, mas os } \\
\text { problemas básicos continuaram os mesmos. Problemas de antena, de } \\
\text { radar, de freqüência, a operacionalidade em si é péssima. Atualmente, eu } \\
\text { tenho que digitar diversas informações e tenho que tirar a minha atenção } \\
\text { da tela para ficar "dedilhando". Eu não sou um datilógrafo!!!. Como } \\
\text { controlador eu presto um serviço de vigilância à vida.... Apesar do } \\
\text { aparente avanço tecnológico existe uma falta de confiabilidade num } \\
\text { sistema que está aquém daquilo que nós temos como necessidade. O } \\
\text { volume de tráfego aumentou... A velocidade das aeronaves aumentou... } \\
\text { É uma realidade! Não houve para o controle de tráfego aéreo o mesmo } \\
\text { desenvolvimento tecnológico. A gente ainda tem o seguinte pensamento: } \\
\text { O elemento humano dificilmente será substituído desse sistema. } \\
\text { Enquanto tiver um controlador, um microfone com rádio confiável e um } \\
\text { lápis que seja com um pedaço de papel... Existe um Controle de Tráfego } \\
\text { Aéreo! Os acessórios eliminam muito a carga de trabalho, mas se você } \\
\text { for confiar demais nisso, você não tem garantia no caso de um corte de } \\
\text { energia, de uma falha no sistema... Então, o que conta é a experiência do } \\
\text { controlador. Existe uma falsa modernidade. Esta parafernália toda é } \\
\text { bonita, mas o sistema é falho! Na verdade, o que a gente sofre aqui não é } \\
\text { uma coisa que eles estejam preocupados. Eles estão preocupados com a } \\
\text { imprensa que vem e filma... É só a casca, porque o restante é o mesmo. }\end{array}$ \\
\hline
\end{tabular}


A introdução de novas tecnologias, de equipamentos cada vez mais avançados e sofisticados é vivida de forma ambígua pelo controlador de tráfego aéreo. O DSC sobre: a falsa modernidade de um sistema tecnologicamente desatualizado é contundente. As representações sociais deste coletivo sobre a automação dos processos traz à tona dúvidas sobre o aparente avanço tecnológico e sobre a falta de confiabilidade no sistema.

"Quando mudaram os equipamentos, a impressão que se teve é que era um doente terminal com vestido novo, porque mudaram as telas, o visual, mas os problemas básicos continuaram os mesmos."

O funcionamento em modo degradado pode ter origem, também, na formação insuficiente que acompanha a introdução das novas tecnologias. A degradação pode ser associada à existência de conhecimentos lacunares dos operadores sobre a utilização ou o funcionamento do novo sistema segundo KERBAL (1989), citado por VIDAL (1984). Esses conhecimentos lacunares resultam, em geral, menos de um problema de competência que de uma insuficiente consideração do saber fazer do operador e da atividade de trabalho no processo de concepção, em particular no que se refere ao plano de formação dos operadores. E, é claro, estas lacunas se agravam diante da variabilidade, conduzindo também à degradação (VIDAL 1984).

\section{“Apesar do aparente avanço tecnológico permaneceu uma falta de confiabilidade num sistema que estava aquém daquilo que nós tínhamos como necessidade".}

Muitas expectativas repousam sobre o aparato tecnológico. São sistemas que são usados, direta ou indiretamente, pelo controlador para a resolução do problema de saturação do espaço aéreo. Conta-se com: radares, telas, dispositivos informatizados, rede de telefonia, etc. Normalmente, deposita-se na tecnologia uma confiança de solução miraculosa. No entanto, o desempenho do sistema de controle do tráfego aéreo parece ser muito mais um problema social e institucional do que técnico (VIDAL e MOREIRA 1999). Fica claro que os operadores não têm como prática a participação na discussão e no planejamento de novos projetos. O discurso do trabalhador denota uma decepção com a posição clássica da Engenharia de Projeto, que tradicionalmente separa concepção de execução, que não considera a riqueza do saber fazer, que não considera a dificuldade de aprendizado das novas tecnologias. 
Sobre a introdução de novas tecnologias no sistema de transporte, verifica-se que o trabalho nestes sistemas concentra-se na vigilância do funcionamento de sistemas complexos. MARSTED (1994) observa que a política de Saúde Ocupacional ${ }^{10}$ precisa estar atenta para as implicações perversas dos novos conceitos de racionalização que vêm sendo adotados. Além de mostrar outros aspectos relevantes, este autor examina as tensões resultantes da percepção, pelos trabalhadores qualificados, das incertezas presentes no âmbito macroeconômico e nas práticas competitivas do mundo globalizado.

“...O elemento humano dificilmente será substituido desse sistema. Enquanto tiver um controlador, um microfone... e um lápis, que seja, com um pedaço de papel... Existe um Controle de Tráfego Aéreo!".

$\mathrm{Na}$ realidade, os altos investimentos em tecnologia ocorrem em detrimento da formação, limitando a capacidade dos novos operadores que já não estão preparados para operar "no modo convencional", como expresso no DSC acima. A dependência da tecnologia torna o trabalhador "refém do sistema", limitando-o em capacidade para enfrentar situações adversas. ZUBOFF (1988) critica a ocorrência de investimentos na órbita de milhões na compra de instalações de novas tecnologias, sem que haja investimentos mínimos em qualificação e treinamento.

"Existe uma falsa modernidade. Isso é muito bonito, mas... o que a gente sofre aqui não é uma coisa que eles estejam preocupados. Eles estão preocupados com a imprensa que vem e filma... É só a casca, porque o restante é o mesmo."

Observa-se, neste contexto, que para além da necessidade de treinamento permanente e de socialização dos conhecimentos sobre o sistema em operação, é preciso que se cultive um clima propício à confiança e transparência administrativa, com existência de planos para política de pessoal. Sem estes elementos, fica difícil alterar a sistemática do Controle de Tráfego Aéreo no Brasil.

\footnotetext{
${ }^{10}$ Pela amplitude que o autor dá à política de Saúde Ocupacional, pode ser entendida como uma política de Saúde do Trabalhador.
} 
O TRABALHO NO CONTROLE DE TRÁFEGO AÉREO.

\begin{tabular}{|c|c|c|}
\hline IdÉIA CENTRAL & EXPRESSÕES-CHAVE & DisCURSO DO SUJEITO COLETIVO \\
\hline $\begin{array}{l}\text { É penoso para o } \\
\text { controlador enfrentar a } \\
\text { dupla jornada de } \\
\text { trabalho. }\end{array}$ & $\begin{array}{l}\text { O nível de exigência deste trabalho é } \\
\text { incompatível com o salário. Eu } \\
\text { tenho que ter duas atividades. O } \\
\text { desgaste é muito grande... Então ele } \\
\text { vai tocando até que alguém perceba } \\
\text { que ele não está bem. }\end{array}$ & $\begin{array}{l}\text { "Minha bíblia é a escala". Antes de dormir preciso saber em que hora e onde } \\
\text { estarei no dia seguinte. Eu não tenho hora de folga para estar com minha } \\
\text { família. Em média eu trabalho mais de } 15 \text { horas por dia, somando as duas } \\
\text { atividades. Hoje eu não tenho paciência com nada, estou sempre preocupado, } \\
\text { tenho perturbações no sono enfim, diversos problemas... O desgaste aqui é } \\
\text { muito grande, não pratico nenhum esporte, estou sempre cansado, o meu } \\
\text { esporte predileto é dormir. O que gera essa ansiedade, esse cansaço é você ter } \\
\text { que conciliar isto aqui com duas ou três atividades aí fora. Só que eu não tenho } \\
\text { como abrir mão disso... meu Deus do céu! Eu não posso trabalhar só para } \\
\text { comer! Isso é inconcebível para uma pessoa que pretenda viver dignamente. } \\
\text { Diante disto, o terror do controlador é ser afastado da escala, pois isto o impede } \\
\text { de cumprir a dupla jornada... Então ele vai tocando até que alguém perceba que } \\
\text { ele não está bem. Mesmo para o supervisor é difícil tomar uma atitude com } \\
\text { relação ao afastamento, pois ele não é médico... nem psicólogo. Eu faço das } \\
\text { "tripas coração", mas prefiro nem ir procurar orientação no órgão responsável. } \\
\text { Se eu fosse lá... Eles me afastariam da escala por problema psicológico, me } \\
\text { drogariam, e depois de um certo tempo diriam: agora você está bom. Na } \\
\text { verdade, todos sabem, inclusive o próprio psiquiatra do HASP, que eu não } \\
\text { deveria fazer nada a mais.... Eu deveria ser controlador e pronto! No horário de } \\
\text { folga eu deveria estar descansando, se possível pescando, porque a gente não } \\
\text { vive só de trabalho. No entanto, o mais grave é que o pessoal acaba se iludindo } \\
\text { com uma escala de serviço que aparenta ser tranqüila... Pois, na verdade, essa } \\
\text { escala não foi criada porque eles gostam do controlador. Existe uma } \\
\text { regulamentação que estabelece um número máximo de horas que você pode } \\
\text { estar operando. Aliás, são padrões internacionais, e quem estabelece isso não é } \\
\text { o nosso chefe, no caso é a OACI. }\end{array}$ \\
\hline
\end{tabular}


Constatou-se que a maioria dos operadores, além da atuação no controle de tráfego aéreo que obedece ao sistema de turnos rodiziantes, acumula outra atividade profissional. O DSC revela: É penoso para o controlador enfrentar a dupla jornada de trabalho. Esta situação é percebida pelos trabalhadores como geradora de cansaço e fadiga, sendo incompatível com uma atividade que exige extrema atenção, precisão de raciocínio e agilidade intelectual.

"Hoje eu não tenho paciência com nada, estou sempre preocupado, tenho perturbações no sono, enfim, diversos problema... O desgaste aqui é muito grande, nem tanto em relação ao próprio trabalho. O que gera essa ansiedade, esse cansaço é você ter que conciliar isto aqui com duas ou três atividades aí fora".

Revela-se no discurso destes trabalhadores as representações sociais sobre sua realidade de desgaste biopsiquicossocial. Alguns estudos como os de MONK e TEPAS 1985; CIPOLLA-NETO 1988; RUTENFRANZ e col. 1989; CRUZ e col. 2000, têm apontado problemas conseqüentes às alterações de ritmos biológicos, causados pelo trabalho em turnos e noturnos. Este sistema de trabalho por si só constitui-se importante perturbador da ritmicidade circadiana, tendo implicações negativas em muitos dos processos biológicos de auto-regulação, além dos conflitos de ordem social e conseqüências sobre a saúde do trabalhador.

O DSC destaca ainda que a principal causa da perda de sono e geradora de estresse do controlador é a falta de dinheiro para o pagamento das contas no final do mês. Existe unanimidade entre os operadores, que qualquer coisa que se faça no sentido de dar melhores condições de trabalho ao controlador de vôo deve passar necessariamente pela melhoria salarial. Ninguém, em sã consciência, discordará de que os controladores de tráfego aéreo devam trabalhar satisfeitos, descansados e bem remunerados (VIDAL e MOREIRA 1999).

No APP-SP a carga horária é de 120 a 128 horas mensais, com 4 pernoites de 8 horas. Normalmente, na atividade complementar, a carga horária é de 180 horas mensais, cumpridas em 5 a 6 dias/semana.

"Em média eu trabalho mais de 15 horas por dia, somando as duas atividades. Hoje eu não tenho 
paciência com nada, estou sempre preocupado, tenho perturbações no sono, enfim diversos problemas."

Diante da absoluta impossibilidade de cumprimento desta carga horária de trabalho, na prática o que se observa é que tanto os turnos como as escalas dentro dos turnos são negociáveis. Isso significa que um operador, dependendo de sua necessidade, "pode abrir mão" de um horário de descanso para sair algumas horas mais cedo do trabalho. Ocorre, ainda, a situação em que alguns operadores não trabalham em turnos alternados, mantendo um turno fixo, em função da necessidade de adequação da segunda jornada de trabalho. Nas duas situações apontadas, o descumprimento de normas é considerado gerador de risco. Na primeira situação, pela supressão das pausas para descanso. Na segunda, pela exposição do operador ao constante estresse do "horário de pico". Neste caso, esse operador estaria diariamente exposto ao horário de maior tráfego, das 7:00 às 10:00 horas, no turno da manhã, ou das 17:00 às 20:00 horas, no turno da tarde. A justificativa técnica para a adoção do sistema de turnos alternados no controle de tráfego aéreo se dá segundo padrões internacionais (adotados pelo Brasil), e tem por objetivo evitar que o trabalhador seja exposto diariamente a uma carga maior de trabalho nestes horários. $\mathrm{Na}$ verdade, todos os padrões, práticas e procedimentos recomendados para o Controle de Tráfego Aéreo e para a aviação em geral devem estar de acordo com o Conselho da Organização Internacional da Aviação Civil.

"No horário de folga eu deveria estar descansando... porque a gente não vive só de trabalho. No entanto, o mais grave é que o pessoal acaba se iludindo com uma escala de serviço que aparenta ser tranqüila... Pois, na verdade, essa escala não foi criada porque eles gostam do controlador".

Quase sempre o intuito dos superiores é colaborar com aqueles que precisam estudar e/ou que estão fazendo algum curso, e até facilitar a manutenção da segunda atividade profissional.

"Na verdade, todos sabem, inclusive o próprio psiquiatra do HASP, que eu não deveria fazer nada a mais.... Eu deveria ser controlador e pronto!". 
Mas este parece ser um benefício intocável para os operadores. Esta maleabilidade para negociar horários faz com que os controladores se submetam a situações de extrema sobrecarga de trabalho.

"O terror do controlador é ser afastado da escala, pois isto o impede de cumprir a 'dupla jornada'... Então ele vai tocando até que alguém perceba que ele não está bem."

Fica claro no DSC que existe medo do afastamento por problemas psíquicos. Pois esta situação obrigaria o controlador a assumir um posto de trabalho na área administrativa. Conseqüentemente, estaria fora da escala, tendo que cumprir uma jornada regular de trabalho. Isto o impediria de cumprir a dupla jornada.

"Só que eu não tenho como abrir mão disso... meu Deus do céu!!! Eu não posso trabalhar só para comer!!! Isso é inconcebivel para uma pessoa que pretenda viver dignamente."

Independentemente dos argumentos sobre riscos à saúde como conseqüência do trabalho em turnos alternados, e/ou a submissão do controlador à carga de estresse diário de um "horário de pico", a situação de risco para a saúde destes trabalhadores parece ser grave.

VIDAL e MOREIRA (1999), afirmam que os salários dos profissionais do Sistema Brasileiro de Controle de Tráfego Aéreo são demasiadamente baixos para o grau de responsabilidade que têm sobre seus ombros. O controle de tráfego aéreo apresenta três critérios diferentes de remuneração: militares em sua maioria, funcionários civis e controladores contratados (INFRAERO). Apesar de exercerem a mesma ocupação, todos recebem salários diferentes e todos eles defasados da importância real de suas tarefas na sociedade. Estes autores argumentam que pela natureza do serviço que prestam, os controladores deveriam ser enquadrados no rol das carreiras de Estado, tal como os juizes, os funcionários do Banco Central e os militares. 
O TRABALHO NO CONTROLE DE TRÁFEGO AÉREO.

\begin{tabular}{|c|c|c|}
\hline \multicolumn{3}{|c|}{ O TRABALHO NO CONTROLE DE TRÁFEGO AÉREO. } \\
\hline IDÉIA CENTRAL & EXPRESSÕES-CHAVE & DisCuRSO do SuJEITO COLETIVO \\
\hline $\begin{array}{l}\text { O controle de tráfego } \\
\text { aéreo é um trabalho de } \\
\text { equipe. }\end{array}$ & $\begin{array}{l}\text { O trabalho em equipe é coeso... } \\
\text { O ambiente de trabalho é } \\
\text { agradável... Muitas vezes, a chefia } \\
\text { quer misturar as pessoas... Aí } \\
\text { começam as brigas, conflitos... }\end{array}$ & $\begin{array}{l}\text { O controle de tráfego aéreo é um trabalho de equipe, por mais que o chefe } \\
\text { queira falar: "ah! você tem que trabalhar independente da equipe". Não adianta. } \\
\text { A boa interação da equipe te faz chegar mais tranqüilo em casa, porque você } \\
\text { sabe com quem está trabalhando e isto te deixa menos estressado. O trabalho } \\
\text { em equipe é coeso, cada um faz a sua parte. Você sempre tem o apoio dos } \\
\text { colegas. Na minha equipe existe respeito ao padrão operacional, o ambiente de } \\
\text { trabalho é agradável. Isso acaba sendo uma compensação. Normalmente não } \\
\text { acontecem besteiras. Mas, quando você comete um erro! Aquilo fica te } \\
\text { martelando. A gente se sente culpado. Mesmo que muitas vezes seja por falhas } \\
\text { do próprio sistema. O papel do supervisor é importantíssimo! A obrigação do } \\
\text { supervisor é alertar para um erro ou um risco. O supervisor também precisa } \\
\text { saber lidar com as diferenças de desempenho dos operadores. Às vezes, você } \\
\text { olha e tem muita gente trabalhando. Mas aquelas pessoas que pegam o } \\
\text { microfone e desempenham de fato é cada vez menor. Essa situação é } \\
\text { preocupante porque os controladores experientes ficam cada vez mais } \\
\text { sobrecarregados, pois além de fazerem as suas funções têm que fazer a dos } \\
\text { outros. Tudo aquilo tem que ser monitorado. Você tem que controlar o } \\
\text { computador e os aviões. Mas, existe equipe em que o operador trabalha } \\
\text { sozinho. A mentalidade é outra. Tem operador que acha que domina o sistema. } \\
\text { O individualismo quebra o espírito de equipe... A pessoa nem pensa que o erro } \\
\text { dela pode significar o risco para muitos! Muitas vezes, na equipe, você resolve } \\
\text { os problemas. Existe muita diferença nas posturas pessoais e desempenho das } \\
\text { equipes. Muitas vezes a chefia quer misturar as pessoas. Aí o que acontece? } \\
\text { Arma problema para ela, porque aí começam as brigas, conflitos, } \\
\text { descontentamentos. Na minha opinião, este espírito de equipe deveria ser } \\
\text { cultivado e incentivado como uma forma de melhorar a qualidade do trabalho e } \\
\text { aumentar a segurança no controle de tráfego aéreo. }\end{array}$ \\
\hline
\end{tabular}


Um aspecto bastante enfatizado no DSC foi o de que o controle de tráfego aéreo é um trabalho de equipe.

"A boa interação da equipe te faz chegar mais tranqüilo em casa, porque você sabe com quem está trabalhando e isto te deixa menos estressado".

O controlador consegue suportar a possibilidade de ocorrência de um acidente e assumir esta pesada responsabilidade e todo o estresse que o acompanha, graças ao grupo. O coletivo dos controladores é muito solidário, manifestando-se por rituais de iniciação muito exigentes (VIDAL e MOREIRA 1999).

"O trabalho em equipe é coeso, cada um faz a sua parte. Você sempre tem o apoio dos colegas. Isso acaba sendo uma compensação. Normalmente não acontecem besteiras."

FERREIRA (1998) em estudo realizado com pilotos refere à atuação do coletivo dos trabalhadores como um forte aliado na garantia de um melhor desempenho técnico da tripulação. Já VIDAL e MOREIRA (1999) identificaram no trabalho coletivo dos operadores vários aspectos positivos para a confiabilidade do sistema. O que está em jogo para a segurança e eficiência do processo é, sobretudo, a capacidade de mobilização das iniciativas individuais frente ao inesperado, o que requer efetividade da dimensão coletiva e a cooperação entre os operadores.

"Os controladores experientes ficam cada vez mais sobrecarregados, pois, além de fazerem as suas funções têm que fazer a dos outros. Tudo aquilo tem que ser monitorado. Você tem que controlar o computador e os aviões".

Sob a ótica metodológica da Análise Ergonômica do Trabalho, pode-se identificar no controle de tráfego aéreo algumas características comuns às dos processos industriais contínuos, como: periculosidade, complexidade, imprevisibilidade, continuidade e caráter coletivo do trabalho. Diante da complexidade do sistema, muitas vezes, os operadores não conseguem compreender os problemas. A concepção e a gestão inapropriadas do ponto de vista da segurança criam uma situação em que o surgimento 
de incidentes que não podem ser controlados pelos operadores acaba sendo inevitável. (ROSA 1989; LANDAU 1995; LLORY 1996)

"Tem operador que acha que domina o sistema. $O$ individualismo quebra o espírito de equipe... A pessoa nem pensa que o erro dela pode significar o risco para muitos!!!”

Os erros humanos no interior dos sistemas complexos seriam tentativas de regulação que não tiveram êxito em conter os desfuncionamentos do processo. Estudos mostram que os operadores desempenham um papel importante no controle das incertezas, assegurando um maior rigor ao funcionamento dos sistemas (ITANI 1996b).

"Na minha opinião este espírito de trabalho em equipe deveria ser cultivado e incentivado como uma forma de melhorar a qualidade do trabalho $e$ aumentar a segurança no controle de tráfego aéreo".

Para ZUBOFF (1988), citado por SELIGMANN-SILVA (1997), a comunicação interpessoal é referida como aspecto fundamental para a construção de um sentido que será percebido pelo conjunto e por parte de cada um dos integrantes do grupo de trabalho. Considera-se ainda a importância da dinâmica do reconhecimento e da dimensão ética das comunicações e interações entre sujeitos dentro deste processo. 


\begin{tabular}{|c|c|c|}
\hline \multicolumn{3}{|c|}{ A EXPERIÊNCIA COM O RISCO NO COTIDIANO DO CONTROLE DE TRÁFEGO AÉREO. } \\
\hline IDÉIA CENTRAL & EXPRESSÕES-CHAVE & Discurso do SuJEITo Coletivo \\
\hline $\begin{array}{l}\text { O controlador de tráfego } \\
\text { convive com o risco no } \\
\text { seu cotidiano de } \\
\text { trabalho. }\end{array}$ & $\begin{array}{l}\text { Um incidente é uma } \\
\text { possibilidade que está sempre } \\
\text { presente.Todos os controladores } \\
\text { fazem o impossível para não } \\
\text { errar, mas errar é humano. }\end{array}$ & $\begin{array}{l}\text { Falta estrutura, faltam condições para que eu desempenhe a minha } \\
\text { profissão com segurança. Na verdade, nós controladores de vôo é que } \\
\text { deveríamos evitar colisões e não o piloto. No entanto, se houver a colisão } \\
\text { quem vai ser preso? Infelizmente, serei eu. Porque eu fui o executor. } \\
\text { Além do mais, por trabalhar desta forma, eu estou sendo omisso, } \\
\text { negligente e conivente. Porque eu sei de todos os problemas, e mesmo } \\
\text { assim, continuo trabalhando. O controlador tem o pensamento de } \\
\text { trabalhar certo, mas acaba criando um incidente... Isso o deixa arrasado... } \\
\text { Com um enorme sentimento de culpa. Mas, em nenhum instante há } \\
\text { preocupação com o bem estar deste profissional por parte da chefia ou do } \\
\text { sistema. Pelo contrário, existe sempre a intenção de identificar um } \\
\text { culpado. O controlador tem um grande medo de sofrer uma punição, de } \\
\text { ser tirado da escala, tudo isso. Mas, ele é um ser humano passível de erro, } \\
\text { às vezes você olha, calcula uma coisa, mas acontece outra. Eu sei que } \\
\text { todo mundo que controla avião faz o impossível para não errar, mas errar } \\
\text { é humano. E, muitas vezes, a condição desencadeadora... não está nesse, } \\
\text { ou naquele controlador, mas, sim, no sistema. É o efeito dominó. Quando } \\
\text { tem um "incidente público" eles investigam, é um trabalho sério. Mas, } \\
\text { normalmente os incidentes não são registrados. Isso aí já é uma } \\
\text { preocupação enorme. São tantos os incidentes que se você for registrar o } \\
\text { sistema pára! Então, o que acontece aqui? O incidente de tráfego aéreo é } \\
\text { banalizado. }\end{array}$ \\
\hline
\end{tabular}




\section{O controlador de tráfego convive com o risco no seu cotidiano de trabalho.}

As Representações Sociais presentes no DSC sobre suas experiências com o risco são expressas de forma viva e contundente.

"Falta estrutura, faltam condições para que eu desempenhe a minha profissão com segurança."

A falta de confiabilidade do operador no sistema 'controladores de vôo-sistemas de radar' é por si só preocupante, neste contexto em que se parte do pressuposto de que a combinação homem-máquina, pelo menos no que diz respeito à parte 'máquina', seja perfeita. Desta forma, o estresse deste trabalhador deve ser compreendido também como um fator de sofrimento para os operadores.

“... se houver a colisão quem vai ser preso?

Infelizmente, serei eu. Porque eu fui o executor...

Então eu sou negligente e conivente. Porque eu sei de

todos os problemas e mesmo assim continuo trabalhando".

Esta realidade, caracterizada pela pressão institucional da hierarquia militar presente no contexto político-administrativo da Aviação Civil Brasileira deve ser considerada como contributiva para uma carga mental adicional de desgaste da fisiologia humana, o que afeta ainda mais a aptidão física para o trabalho.

"Eu sei que todo mundo que controla avião faz o impossivel para não errar, mas errar é humano. E, muitas vezes, a condição desencadeadora... não está nesse ou naquele controlador, mas, sim, no sistema. $\dot{E}$ $o$ 'efeito dominó".

O "efeito dominó" utilizado por REASON (1990), considera que para a ocorrência de um acidente, a contribuição humana está normalmente relacionada a uma posição hierárquica de "não governabilidade" do sistema. A contribuição humana nos acidentes deve distinguir falhas ativas e falhas latentes, em função do efeito desfavorável imediato ou não sobre o sistema. A principal característica das falhas latentes é que elas estão presentes no interior dos sistemas muito tempo antes de um acidente acontecer, sendo introduzidas por níveis hierárquicos superiores ligados ao sistema institucional e administrativo. Assim, uma atuação fundamental no sentido de melhorar a confiabilidade de um sistema está na identificação dessas falhas latentes. 
"Quando tem um incidente público eles investigam, é um trabalho sério. Mas, normalmente, os incidentes não são registrados. São tantos os incidentes que, se você for registrar, o sistema pára! Então o incidente de tráfego aéreo é banalizado".

O objetivo do sistema é controlar todos os fatores provocadores de desvios, procurando eliminá-los sistematicamente, sejam eles humanos ou técnicos. Esta filosofia gerencia a segurança nos grandes sistemas aeronáuticos, pautando-se nos bancos de dados estatísticos e permitindo a realização dos estudos de análise de riscos. Nos EUA, o Aviation Safety Reporting System - ASRS coleta, analisa e armazena dados a partir de informações relatadas espontaneamente, pelos trabalhadores do transporte aéreo, sobre as situações de incidentes. Os trabalhadores são incentivados a registrar em relatório específico os eventos críticos de incidentes. A participação voluntária se dá na perspectiva de minimizar as probabilidades de acidentes aéreos. Pilotos, controladores de tráfego, comissários de bordo, mecânicos (inclusive pessoal de terra), são sensibilizados a relatar para o ASRS os fatos ocorridos, sempre que estão diretamente envolvidos ou quando observaram um incidente ou situação na qual a segurança da aviação estava comprometida. Toda participação é espontânea. Os relatórios encaminhados ao ASRS são mantidos em estrita confidência.

No que diz respeito ao Sistema Brasileiro de Controle de Tráfego Aéreo, constatou-se a não existência de relatórios estatísticos da taxa de incidentes e acidentes, por isso, não é possível extrapolar tendências futuras e efetivamente trabalhar-se na perspectiva da prevenção.

Os dados sobre acidentes aéreos encontram-se no Centro de Investigação e Prevenção de Acidentes Aeronáuticos-CENIPA. Este órgão é subordinado ao Departamento de Aviação Civil -DAC. O acesso aos relatórios estatísticos não é assegurado publicamente, não sendo viável, portanto, a realização de estudos que permitam aprofundar a causalidade dos eventos. A falta de uma política preventiva de incentivo à produção dos relatórios de incidentes, que garanta sobretudo a confidencialidade às informações prestadas pelos trabalhadores deste sistema, sugere que os dados do DAC sejam subestimados ou não estejam devidamente registrados. 
Este contexto tem como resultado a impossibilidade de realização de Estudos Epidemiológicos de Incidentes Aeronáuticos, particularmente a construção das taxas de freqüência, dificultando uma ação preventiva, segura e efetiva de eventos cujo potencial de gravidade, por si só, já é suficiente para considerar sua ocorrência como um grave problema de saúde pública. Os trabalhos de pesquisa produzidos com base nos dados do DAC, de um modo geral, se restringem a Estudos Seccionais Clássicos, que investigam a ocorrência de acidentes de forma pontual (MEIRA 1983; MAIA 1989; SAMPAIO 1989). Investigações deste tipo, quando muito, geram conclusões que se limitam a dimensionar os agravos a partir do evento já ocorrido, ou seja, constituem-se em informações pós-fato acidentário (VASCONCELLOS e RIBEIRO 1995). Não é muito difícil imaginar que, pela própria desatenção governamental para com a área, poderão ocorrer problemas em curto prazo (VIDAL e MOREIRA 1999). 


\section{A EXPERIÊNCIA COM O RISCO NO COTIDIANO DO TRABALHO DO CONTROLE DE TRÁFEGO AÉREO}

\begin{tabular}{|c|c|c|}
\hline IdÉIA CENTRAL & EXPRESSÕES-CHAVE & DisCuRSO do SuJEITo Coletivo \\
\hline $\begin{array}{l}\text { A produção da } \\
\text { consciência culposa na } \\
\text { contramão da saúde do } \\
\text { trabalhador. }\end{array}$ & $\begin{array}{l}\text { Normalmente na vida você é } \\
\text { inocente até que se prove a sua } \\
\text { culpa, no controle de tráfego é o } \\
\text { contrário, "o controlador é } \\
\text { culpado" até que se prove a sua } \\
\text { inocência. }\end{array}$ & $\begin{array}{l}\text { A gente tem como experiência que o controlador é culpado até que se } \\
\text { prove a sua inocência. Então, muitas vezes, eles vão descobrir lá no } \\
\text { fundo que um controlador em vez de falar "positivo", falou "OK" ou } \\
\text { falou "sim"!!! Se prendem muitas vezes a certas "firulas" e escapam do } \\
\text { assunto central. Na verdade existem situações onde fico absolutamente } \\
\text { perdido... O sistema não te dá a informação que você precisa... só que } \\
\text { você não tem tempo de pensar duas vezes... então você usa tudo que você } \\
\text { tem e decide... E tem que ganhar. Este é um dos fatores mais estressantes } \\
\text { deste trabalho. O piloto de certa maneira tem muito mais autonomia. Ele } \\
\text { tem muito mais liberdade do que a gente. Na maioria das vezes é mais } \\
\text { fácil taxar o controlador de incompetente... É muito mais fácil você pegar } \\
\text { o controlador... Foi o fulano. Some com esse sujeito. Olha! o problema } \\
\text { foi resolvido. O controlador número tal não existe mais. Pronto! Se for } \\
\text { comprovado que houve uma falha do controlador ele vai ser execrado, } \\
\text { suas terras serão salgadas até a sua quinta geração. E tudo ficará } \\
\text { resolvido. }\end{array}$ \\
\hline
\end{tabular}


A produção da consciência culposa na contramão da saúde do trabalhador foi uma idéia central destacada nos DSCs. As expressões-chave que caracterizam este discurso são colocadas de todas as formas e cores, inclusive com riqueza poética. Explicita-se, neste discurso, que o pensamento de uma comunidade é representado pelo seu imaginário resgatado.

"A gente tem como experiência que o controlador é culpado até que se prove a sua inocência. Se for comprovado que houve uma falha do controlador, ele vai ser execrado, suas terras serão salgadas até a sua quinta geração. O controlador número tal não existe mais. Pronto!"”.

A saída simplista que tem sido dada às situações de risco de acidentes de trabalho mostra como a sociedade atual não reconhece as deficiências de suas concepções, atribuindo a responsabilidade pelo acidente ao operador, "a produção da consciência culposa". Lamentavelmente, no que diz respeito à gênese dos acidentes de trabalho, a concepção unicausal, calcada sobretudo em fatores humanos, entendidos como descuido, negligência, imprudência, entre outros, ainda prevalece (SILVA 1996).

“... Muitas vezes eles vão descobrir lá no fundo da coisa que um controlador em vez de falar "positivo", falou "ok" ou falou "sim"??? Se prendem muitas vezes a certas "firulas" e escapam do "assunto central".

A cultura da culpa calcada sobretudo em fatores humanos, entendidos como descuido, negligência, imprudência ainda prevalece. Em decorrência, as investigações não diagnosticam as verdadeiras causas do acidente de trabalho, mas somente identificam culpados (COHN 1985). Os fatores causais de acidentes estão normalmente relacionados com práticas de organização do trabalho e decisões gerenciais, que apontam necessidade de revisão da legislação, de práticas de negociação e sobretudo de confiança e reconhecimento do saber do trabalhador.

A cultura das relações de trabalho no Brasil não estimula a busca de soluções dos conflitos por meio de processos negociais entre as partes, BONCIANI (1996). Ao invés, a tradicional postura fiscalizatória e punitiva prevalece, especialmente, se considerarmos a visão cultural hegemônica presente na hierarquia militar. A organização destes profissionais em contraposição à compulsoriedade da instituição, apesar da rigidez disciplinar e do pouco acúmulo de conhecimento e experiências para a formulação de 
propostas que definam princípios técnicos e éticos de ações de mediação, parece ser essencial para os controladores.

"O piloto de certa maneira tem muito mais autonomia.

Ele tem muito mais liberdade do que a gente. Na

maioria das vezes é mais fácil taxar o controlador de

incompetente".

Há que se considerar, entre as questões apontadas pelos operadores, a insuficiente formação que acompanha a introdução das novas tecnologias. Conforme KERBAL (1989), esta pode ser causa da existência de conhecimentos lacunares sobre a utilização ou o funcionamento dos novos sistemas. Esses resultam, em geral, menos de um problema de competência que de uma insuficiente consideração do saber fazer do operador e da atividade de trabalho no processo de concepção tecnológica. No entanto, o que se observa é que os sistemas complexos têm como característica a invisibilidade da ação e das condições de realização para o operador (ITANI 1998).

"Na verdade existem situações onde fico absolutamente perdido... O sistema não te dá a informação que você precisa... Só que você não tem tempo de pensar duas vezes... Então você usa tudo que você tem e decide... E tem que ganhar!!!".

Os sistemas e equipamentos automatizados apresentam novas exigências em suas operações. A atividade dos operadores no manejo de equipamentos superavançados e altamente complexos é permeada de incertezas e inquietações. Neste contexto, percebese na lógica do Sistema de Investigação e Prevenção de Acidentes Aeronáuticos (SIPAER) uma tendência à linearidade na explicação das causas de incidentes e acidentes, tendo normalmente como principal suspeito a priori o operador.

"É muito mais fácil você pegar o controlador... Some com esse sujeito. O problema foi resolvido".

Senão, até por falta de investimentos na área, o SIPAER estará fazendo somente (como há muito vem acontecendo) a parte investigativa dos acidentes, com a ação preventiva sempre sendo prejudicada por medidas apenas paliativas (VIDAL e MOREIRA 1999).

Essa concepção atávica, segundo VIDAL (1984), predominava nos sistemas de trabalho das corporações medievais. Essa corrente admite que a segurança seja, em parte, responsabilidade do trabalhador, não admitindo outras causas relativas ao processo de trabalho e administração e, portanto, com uma divisão de responsabilidade mais ampla. 


\begin{tabular}{|c|c|c|}
\hline \multicolumn{3}{|c|}{ A EXPERIÊNCIA COM O RISCO NO COTIDIANO DO TRABALHO DO CONTROLE DE TRÁFEGO AÉREO. } \\
\hline IDÉIA CENTRAL & EXPRESSÕES-CHAVE & DisCuRSo do SuJEITo Coletivo \\
\hline $\begin{array}{l}\text { Os riscos para a } \\
\text { sociedade }\end{array}$ & $\begin{array}{l}\text { Como controlador de tráfego } \\
\text { sei qual é a minha } \\
\text { responsabilidade. O volume de } \\
\text { tráfego triplicou nos últimos } \\
\text { cinco anos e estamos com o } \\
\text { mesmo número de operadores. }\end{array}$ & $\begin{array}{l}\text { Como controlador de tráfego sei qual é a minha responsabilidade. Mas eu } \\
\text { acho que todos teriam que ter consciência, principalmente os superiores. } \\
\text { A determinação das chefias em não prejudicar as pessoas tinha que ser } \\
\text { levada muito mais a sério. No entanto, há dificuldades com a manutenção } \\
\text { dos equipamentos, com a falta de pessoal qualificado, com os } \\
\text { controladores que estão super estressados. A cultura "de empurrar com a } \\
\text { barriga", de "quebrar galho" aliada com a burocracia militar dificulta } \\
\text { tudo. Os militares têm muito medo que aconteça o pior, mas não têm } \\
\text { consciência dos riscos que estão presentes aqui. Este equipamento está } \\
\text { com uns três, quatro anos de uso e começa a exigir manutenção e você } \\
\text { não tem. A burocracia administrativa faz com que uma pessoa que } \\
\text { desconheça o que é aquilo decida o que vai ser comprado! Então, a } \\
\text { prioridade vai ser aquela que ela achar que tem de ser! Na verdade, são } \\
\text { dois problemas graves no controle de tráfego: primeiro - por ser público } \\
\text { todos os cargos de confiança são políticos. Segundo, por ser militar - o } \\
\text { cargo de chefia do APP-SP, que deveria ser ocupado por um Controlador } \\
\text { de Tráfego Aéreo, não é. Mas, não é fácil manter o profissionalismo com } \\
\text { um equipamento que não funciona, um sistema de radar que falha, um } \\
\text { VHF que é um terror... Só que para todos os efeitos está tudo } \\
\text { funcionando muito bem. Ser controlador de vôo é perigoso, porque você } \\
\text { vive de cara com o risco. Você tem que suprir as suas deficiências } \\
\text { técnicas, as deficiências dos equipamentos e esquecer que você ganha } \\
\text { muito mal! Aqui você tem que se desdobrar. O volume de tráfego } \\
\text { triplicou nos últimos cinco anos e estamos com o mesmo número de } \\
\text { operadores. Esta situação envolve risco à vida de muitas pessoas. }\end{array}$ \\
\hline
\end{tabular}


Os DSC dos trabalhadores sobre os riscos para a sociedade será discutido sob a ótica da dimensão ambiental e do controle social do risco. Revela-se, nas representações sociais dos operadores, a expressão de preocupação, de responsabilidade e de impotência diante da rigidez da estrutura militar.

"... Como controlador de tráfego sei qual é a minha responsabilidade. Mas eu acho que todos teriam que ter consciencia, principalmente os superiores".

O risco decorrente de acidentes no transporte não é uma questão restrita à saúde do trabalhador. É um problema que envolve a sociedade contemporânea (ITANI 1996b). Apesar das inovações tecnológicas na aviação, as ocorrências de risco são freqüentes e envolvem um número cada vez maior de pessoas e situações sociais. Algumas experiências institucionais e acadêmicas neste campo vêm revelando uma tendência à ampliação espacial, ecológica e social, tanto dos efeitos como da percepção e tematização pública dos riscos decorrentes das sociedades industriais contemporâneas. O atual momento histórico aponta para a importância da reflexão a respeito dos impactos sobre a saúde e o meio ambiente resultantes dos sistemas tecnológicos complexos.

Há dificuldades com a manutenção dos equipamentos, com a falta de pessoal qualificado, com os controladores que estão super estressados... A cultura 'de empurrar com a barriga' 'de quebrar galho' aliada com a burocracia militar dificulta tudo.

As dificuldades estruturais nas análises de riscos tecnológicos ambientais, de acordo com WYNNE (1992), têm sua origem nos limites e incertezas do campo. No sistema de controle de tráfego aéreo, parte-se do pressuposto de que os riscos à segurança presentes no interior do sistema estejam intelectualmente e metodologicamente estruturados, tais como tecnologias adotadas em processos contínuos, em plantas químicas e nucleares. As análises de riscos são parte integral do projeto tecnológico, exercendo o papel de influenciar no estabelecimento de um modo normativo. Entretanto, é importante observar que nos sistemas complexos, os problemas têm se mostrado bem menos estruturados, definidos e controlados do que acreditavam os analistas de riscos e projetistas de tecnologias. (PORTO e FREITAS 1997). Neste cenário de incertezas, em que situações surpreendentes e não previstas sistematicamente 
ocorrem (PERROW 1984), acrescentam-se as dificuldades inerentes à administração governamental da Aviação Civil Brasileira por meio do Comando Maior da Aeronáutica.

"A burocracia administrativa faz com que uma pessoa que desconheça o que é aquilo decida o que vai ser comprado! Então, a prioridade vai ser aquela que ela achar que tem de ser!".

Paradoxalmente à realidade de grande incremento das técnicas de análise de riscos atualmente reconhecendo-se, até, serem os riscos fortemente determinados por questões administrativas. Concordando com VIDAL e MOREIRA (1999), reconhece-se que o Controle de Tráfego Aéreo está no centro de diversos interesses convergentes ou contraditórios, de diferentes atores que possuem visões diferenciadas do que seja desempenho. Constata-se que o governo brasileiro, através de seu Ministério da Defesa, parece não perceber, seja no caso do sistema de controle de tráfego e seus riscos tecnológicos (WYNNE 1987; PERROW 1984), seja no caso do impacto ambiental, que inevitavelmente envolvem a geração e as conseqüências das situações e eventos de riscos. (WYNNE 1989, 1992). Existe entretanto unanimidade no aspecto da segurança. Aponta-se a vulnerabilidade dos trabalhadores, dos passageiros, dos moradores e dos cidadãos em trânsito nas proximidades dos aeroportos.

"Na verdade, são dois problemas graves no controle de tráfego: primeiro, por ser público, todos os cargos de confiança são políticos. Segundo, por ser militar, o cargo de chefia que deveria ser ocupado por pessoas do próprio serviço, não é”.

Todas estas questões vêm destacando a necessidade de repensar o atual paradigma que orienta as avaliações de riscos no âmbito da saúde pública. Considerar a tecnologia, o meio ambiente e o risco como resultantes de processos sociais conduz à formulação de uma nova visão de gerenciamento de riscos, em que são considerados aqueles que percebem os riscos (populações vizinhas e trabalhadores), as instituições públicas e privadas envolvidas-entendidas como porta vozes de interesses sociais, políticos e econômicos estruturados na sociedade e os contextos sociais e culturais em que o risco é analisado e gerenciado (BRADBURY 1989). 
Esta abordagem holística do conjunto de problemas ambientais e seus efeitos é respaldada pelas ações de Promoção de Saúde, que têm como pressuposto a formulação de políticas públicas saudáveis, envolvendo setores públicos e privados e estabelecendo parcerias e alianças entre os diversos setores da sociedade (MENDES 2000).

"A experiência aqui te exige, você realmente tem que se superar. Você tem que suprir as suas deficiências técnicas, as deficiências dos equipamentos... Aqui você tem que se desdobrar. O volume de tráfego triplicou nos últimos cinco anos. Esta situação envolve risco à vida de muitas pessoas"

Neste contexto crítico, cercado de riscos, os quais se relacionam e ultrapassam o universo do ambiente de trabalho, considera-se importante não somente incorporar as percepções e atitudes daqueles, que por se encontrarem expostos aos riscos, têm a dimensão do problema, mas também desenvolver estratégias de análise e decisão que possibilitem uma efetiva participação desses atores sociais, como trabalhadores da aviação, passageiros e comunidades vizinhas e toda a sociedade (OTWAY 1992). 


\begin{tabular}{|c|c|c|}
\hline \multicolumn{3}{|c|}{ AS PRÁTICAS DE SAÚDE DO CONTROLADOR DE TRÁFEGO AÉREO } \\
\hline IDÉIA CENTRAL & EXPRESSÕES-CHAVE & DisCuRSO do SuJEITO COLETIVO \\
\hline $\begin{array}{l}\text { Os médicos do HASP } \\
\text { não conhecem a } \\
\text { realidade de trabalho do } \\
\text { controlador de tráfego } \\
\text { aéreo. }\end{array}$ & $\begin{array}{l}\text { A avaliação médica hoje é um } \\
\text { problema público... Porque não } \\
\text { é possível que eles falem apto, } \\
\text { apto... O que você faria diante } \\
\text { de um profissional que } \\
\text { estivesse revoltado, } \\
\text { desesperançado, estressado? }\end{array}$ & $\begin{array}{l}\text { A avaliação médica hoje é um problema público. A aeronáutica se dá ao } \\
\text { direto de avaliar todo mundo: controlador, piloto, comissário.... Não tem } \\
\text { condição para isso. Não é possível acreditar que num exame eles } \\
\text { consigam descobrir se realmente o indivíduo tem algum tipo de } \\
\text { problema, se ele está sofrendo algum tipo de pressão, se está estressado, } \\
\text { se está depressivo. O psiquiatra não conhece o meu serviço, ele nunca } \\
\text { veio aqui. Então, ele se limita a perguntar: você está bem? Como está o } \\
\text { tráfego? A pergunta é sempre igual! Eu questionei o Major que me } \\
\text { atendeu no HASP... Porque não é possível que eles falem apto, apto... } \\
\text { para todo mundo que passe por eles. Ninguém sabe o que é estar apto } \\
\text { para enfrentar o estresse que nós enfrentamos. Você sabe qual é } \\
\text { exatamente o serviço de um controlador de tráfego aéreo? Você já entrou } \\
\text { lá na sala do controle? Vocês vão deixar o quê? Esperar acontecer um } \\
\text { acidente? Mostrei minhas preocupações e questionei! No dia que eu fizer } \\
\text { algo errado e atravessar dois Boeings vão no mínimo uns trezentos! Ele } \\
\text { concordou... É, realmente, eu acho que o controlador tem que se dedicar } \\
\text { só àquilo e na hora de folga tem que ter um hobby tipo aeromodelismo... } \\
\text { Não vejo nenhuma preocupação com a prevenção. É pública e notória a } \\
\text { questão da dupla jornada. Todos sabem que esta é uma atividade que } \\
\text { exige preparo, concentração, paz mental... O que você faria diante de um } \\
\text { profissional que estivesse revoltado, desesperançado, estressado? Você } \\
\text { atestaria que ele está apto? }\end{array}$ \\
\hline
\end{tabular}




\section{Os médicos do HASP não conhecem a realidade de trabalho do controlador}

de tráfego aéreo. A contundência desta idéia central será expressa pelas representações sociais encadeadas no DSC.

"A avaliação médica hoje é um problema público. A aeronáutica se dá ao direto de avaliar todo mundo: controlador, piloto, comissário.... Não tem condição para isso. Não é possível acreditar que num exame eles consigam descobrir se realmente o individuo tem algum tipo de problema, se ele está sofrendo algum tipo de pressão, se está estressado, se está depressivo".

Este discurso revela claramente a consciência destes profissionais sobre os riscos à saúde presentes nesta atividade. Na maioria das vezes, o trabalho do controlador é desconhecido, até pelos próprios médicos responsáveis pela inspeção de saúde realizada pelo Hospital da Aeronáutica de São Paulo - HASP.

"O psiquiatra não conhece o meu serviço, ele nunca veio aqui. Então, ele se limita a perguntar:_Você está bem? Como está o tráfego? A pergunta é sempre igual!!!”

Nos EUA, desde 1960, estudos sobre a saúde dos controladores vêm sendo desenvolvidos sob o auspício do Federal Aviation Administration. Neste sentido, o FAA, propôs, a partir dos estudos de MOHLER, já em 1983, o estabelecimento de programas de treinamento em técnicas de relaxamento físico e mental, que podem contribuir no controle da hipertensão e como estratégias que aliviem tensões, evitando, assim, a busca do álcool e drogas pelos controladores.

No Brasil, todos os controladores são regularmente submetidos a inspeções de saúde pelo Sistema de Saúde da Aeronáutica. Fica evidente no discurso deste trabalhador, a falta de confiança neste serviço. Revela-se, no discurso deste sujeito coletivo, o desconhecimento dos profissionais de saúde do HASP sobre a organização do trabalho no controle de tráfego aéreo.

"Eu questionei o Major que me atendeu no HASP... Porque não é possível que eles falem apto, apto... para todo mundo que passe por eles. Ninguém sabe o que é estar apto para enfrentar o estresse que nós enfrentamos. Você sabe qual é exatamente o serviço de um controlador de tráfego aéreo? Você já entrou lá na sala do controle?" 
Ressalta-se a importância do conhecimento das responsabilidades éticas e legais quanto à saúde dos trabalhadores, que permite ao profissional de saúde responsável pelo atendimento do trabalhador entender o universo complexo e variado no qual se insere, valorizar sua atuação, além de identificar perspectivas preventivas. (MENDES e DIAS 1991). O sentido da palavra apto pressupõe o grau de equilíbrio mental necessário ao desempenho da função.

"Vocês vão deixar o quê? Esperar acontecer um
acidente? Mostrei minhas preocupações e
questionei!!! No dia que eu fizer algo errado e
atravessar dois Boeings vão no mínimo uns trezentos!
Ele concordou... E E realmente, eu acho que o
controlador tem que se dedicar só àquilo e na hora de
folga tem que ter um hobby tipo aeromodelismo..."

Parece clara a percepção deste coletivo sobre a relação positiva entre condição de saúde, capacidade de desempenho e segurança do sistema. Mas, na verdade, os controladores de tráfego aéreo são submetidos regularmente a inspeção de saúde que simplesmente define-os como "fisicamente aptos". O objetivo do Check-up se resume em detectar se estes trabalhadores gozam de boa saúde. Segundo VIDAL e MOREIRA (1999), nada garante que os controladores de tráfego aéreo estejam em condições de suportar o estresse de uma desgastante jornada de trabalho, sem perda da eficácia profissional. Esses pesquisadores avaliam, ainda, que dentro da sala de controle de vôos, os radaristas lidam simultaneamente com as trajetórias de dezenas de aeronaves, que precisam ser gerenciadas numa ordem precisa. "Uma liturgia que, se contrariada nos menores detalhes, pode ocasionar um acidente”.(VIDAL e MOREIRA 1999 p. 10).

"Não vejo nenhuma preocupação com a prevenção. É pública e notória a questão da dupla jornada. Todos sabem que esta é uma atividade que exige preparo, concentração, paz mental..."

Acredita-se que todas estas questões apontadas por este sujeito coletivo colocam em discussão a responsabilidade institucional do Comando Maior da Aeronáutica. O controlador de vôo desempenha uma atividade que possui características especiais. A responsabilidade que ela exige é impressionante, pois se ele falhar pode comprometer a vida de milhares de pessoas. 


\begin{tabular}{|l|l|l|}
\hline \multicolumn{1}{|c|}{ AS PRATICAS DE SAÚDE DOS TRABALHADORES DA AVIAÇÃO SOB O OLHAR DO CONTROLADOR DE TRÁFEGO AÉREO. } \\
\hline \multicolumn{1}{|c|}{ IDÉIA CENTRAL } & \multicolumn{1}{|c|}{ EXPRESSÕES-CHAVE } & \multicolumn{1}{c|}{ DISCURSO DO SUJEITO COLETIVO } \\
\hline $\begin{array}{l}\text { O controlador de tráfego } \\
\text { aéreo não recebe um } \\
\text { acompanhamento } \\
\text { psicológico adequado. }\end{array}$ & $\begin{array}{l}\text { O acompanhamento psicológico } \\
\text { do HASP não existe. Não se } \\
\text { ouve falar em nenhum tipo de } \\
\text { apoio psicológico aos } \\
\text { operadores. }\end{array}$ & $\begin{array}{l}\text { Não existe um acompanhamento psicológico, nem no próprio serviço, } \\
\text { nem no HASP. O que se tem lá é apenas um exame burocrático. Quando } \\
\text { acontece um acidente, os operadores não têm nenhum acompanhamento } \\
\text { psicológico... O controlador fica em estado de choque e uma insegurança } \\
\text { se abate sobre ele diante da busca de explicações para o ocorrido. A } \\
\text { estrutura do serviço deveria estar preparada para, situações de } \\
\text { emergência no aeroporto e ter como substituir, em pouco tempo a equipe } \\
\text { abalada por outra em condições emocionais favoráveis. Por mais } \\
\text { autocontrole que eu tenha, às vezes, é claro, isto fica impossível... Já tive } \\
\text { que fazer das "tripas coração" aqui na torre. Não se ouve falar em } \\
\text { nenhum tipo de apoio psicológico aos operadores. Se eles quisessem } \\
\text { fazer algo poderiam influir para que houvesse um acompanhamento } \\
\text { psicológico no ambiente de trabalho. Por outro lado, é pouco provável } \\
\text { que alguém em uma entrevista com o psicólogo demonstre um problema } \\
\text { que ele está vivendo na prática. No entanto, de uns tempos para cá a } \\
\text { inspeção de saúde tem sido diferente. Tanto que no ano passado, vários } \\
\text { colegas foram afastados, alguns por uns dias outros por mais tempo. Eles } \\
\text { estão vendo que a situação é crítica. No APP-SP a chefia igualmente tem } \\
\text { sido pressionada principalmente pela mídia. Não dá prá se acomodar } \\
\text { diante da situação de risco de acidentes que temos. É preciso que haja } \\
\text { maior responsabilidade deste serviço. }\end{array}$ \\
\end{tabular}


As representações sociais expressas no DSC sobre a realidade das práticas de saúde institucionais revelam que o controlador de tráfego aéreo não recebe um acompanhamento psicológico adequado, por parte do órgão responsável pelas “inspeções de saúde”. Estas avaliações são realizadas anualmente pelo Hospital da Aeronáutica de São Paulo nos operadores militares e, a cada dois anos, nos civis, sendo normatizadas de acordo com a IMA-Saúde que segue determinações da OACI.

"Não existe um acompanhamento psicológico, nem no próprio serviço, nem no HASP. O que se tem lá é apenas um exame burocrático. Quando acontece um acidente, os operadores não têm nenhum acompanhamento psicológico... O controlador fica em estado de choque e uma insegurança se abate sobre ele diante da busca de explicações para o ocorrido"

Os efeitos psicológicos de acidente aéreo para os controladores de tráfego aéreo denotam sintomas como: estresse, depressão, traumas. Estudos sugerem que mesmo os acidentes não fatais podem ter graves conseqüências psicológicas para os operadores. Diante das implicações emocionais dos acidentes aéreos sobre o desempenho dos trabalhadores, algumas medidas têm sido adotadas para ajudar na recuperação do processo traumático. Entre elas, cita-se a garantia de informação sobre o acidente, a adoção de ações preventivas, tais como criação de grupos de apoio e auto-ajuda, garantia de direito à assistência psicológica, entre outros. (LAMOUREX 1999) (SLAGLE et al 1990)

“A estrutura do serviço deveria estar preparada
para, em situações de emergência no aeroporto, ter
como substituir, em pouco tempo, a equipe abalada
por outra em condições emocionais favoráveis. Por
mais autocontrole que eu tenha, às vezes, é claro, isto
fica impossível... Já tive que fazer das tripas coração
aqui na torre".

O instrumental da Psicodinâmica do Trabalho cujo referencial analítico integra o trabalho à análise das vivências humanas, vem buscando através da Psicologia do Trabalho e do conceito de sofrimento mental (DEJOURS 1980) compreender a "cultura do controle", em que o autocontrole é erigido como um valor essencial pelos próprios 
controladores. Sob a luz deste referencial, o próprio DEJOURS faz uma análise das condições de trabalho do piloto de caça, analisando o sofrimento e os mecanismos de defesa destinados a contê-los, pela organização do trabalho. Nesta concepção, o trabalho em máquinas de alta complexidade tecnológica é assegurado pelo mito da segurança absoluta, em que a confiabilidade é vital. No universo das representações, cria-se, no caso do controlador, a auto-imagem do "homem que tudo controla", até a própria dor (SELIGMANN-SILVA 1997). A sensação de autonomia e onipotência cria a imagem de poder "ter em mãos o próprio piloto", que, por sua vez, "faz a máquina voar". Estes aspectos, entre outros, contribuem para a elaboração de defesas específicas, que se identificam coletivamente numa ideologia defensiva da profissão (DEJOURS 1992).

"Não se ouve falar em nenhum tipo de apoio psicológico aos operadores... Eles estão vendo que a situação é crítica. No APP-SP a chefia igualmente tem sido pressionada principalmente pela mídia. Não dá para se acomodar diante da situação de risco de acidentes que temos. É preciso que haja maior responsabilidade deste serviço".

A inserção política e institucional da Saúde do Trabalhador reconhece a importância do seu diálogo entre os atores sociais; a necessidade da abordagem interdisciplinar; a incorporação do saber e da participação daqueles que se encontram expostos aos riscos, tanto nas avaliações como nos processos decisórios. Qualquer proposta de avanço que não considere estes aspectos poderá representar apenas uma encenação para legitimar os interesses vigentes de ocultamento dos limites e incertezas presentes no sistema. (PORTO e FREITAS 1977). Contata-se, neste discurso, que o controle social exercido pelo coletivo destes trabalhadores tem atuado, tanto no âmbito interno institucional, como no plano da esfera pública, mobilizando opiniões. A imprensa, ainda que de forma restrita, tem ampliado o conhecimento do grande público. A parcela usuária do transporte aéreo também se destaca como formadora de opinião. 


\begin{tabular}{|c|c|c|}
\hline \multicolumn{3}{|c|}{ AS PRÁTICAS DE SAÚDE DO CONTROLADOR DE TRÁFEGO AÉREO } \\
\hline IDÉIA CENTRAL & $\begin{array}{c}\text { EXPRESSÕES- } \\
\text { CHAVE }\end{array}$ & DISCURSO dO SUJEITO COLETIVO \\
\hline $\begin{array}{lrr}\text { Os riscos } & \text { e } & \text { os } \\
\text { agravos à saúde do } & \\
\text { controlador } & \text { de } \\
\text { tráfego aéreo. } & \\
\end{array}$ & $\begin{array}{l}\text { Há pressão de todo la } \\
\text { Esta situação me deix } \\
\text { É o coração batendo } \\
\text { rápido, o metabolismo } \\
\text { acelerado. A cada dia } \\
\text { sinto pior... Mas não } \\
\text { parar. } \\
\\
\end{array}$ & 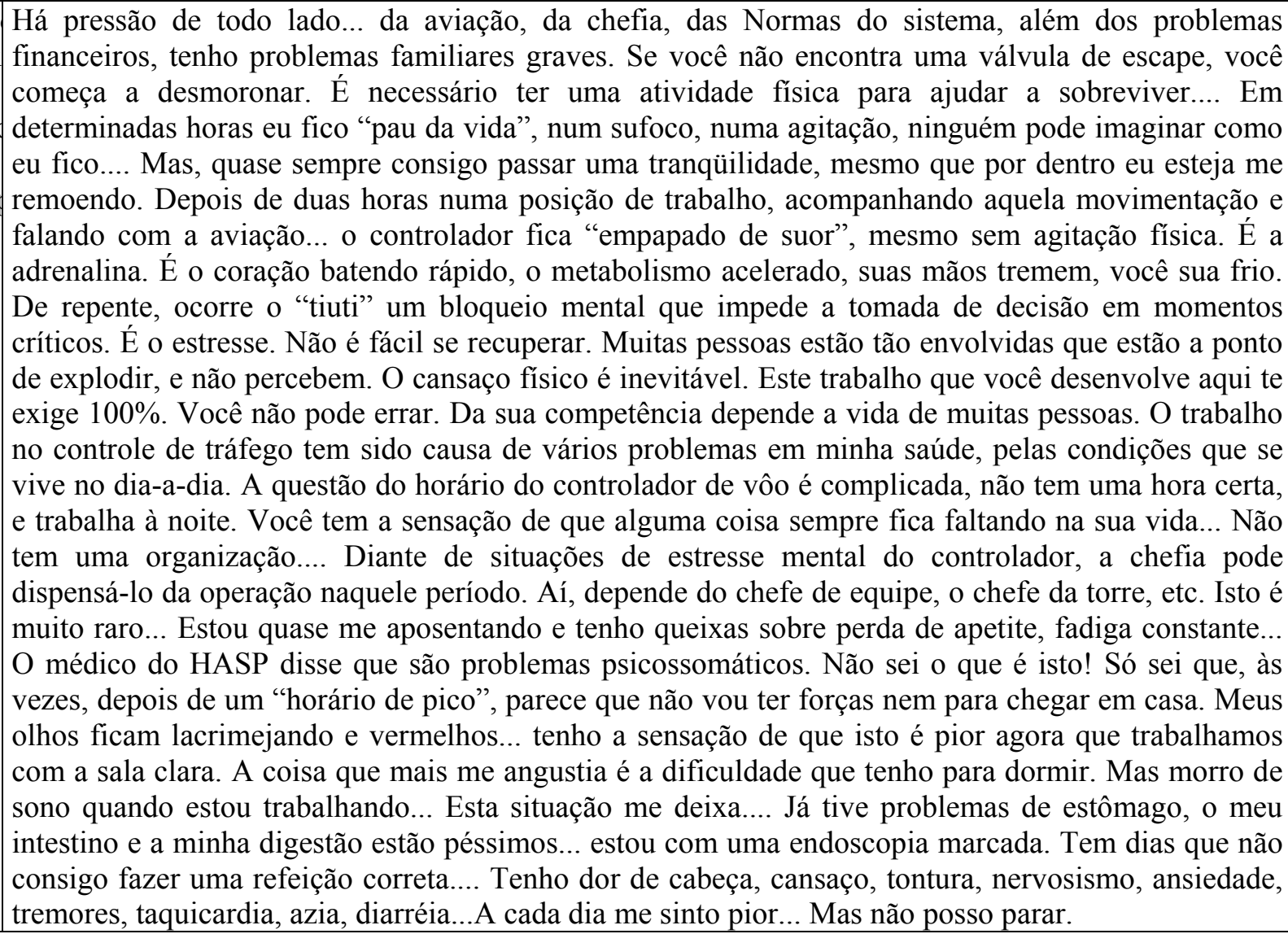 \\
\hline
\end{tabular}


As representações sociais presentes no DSC sobre os riscos e os agravos à saúde do controlador de tráfego aéreo expressam uma realidade em que os trabalhadores parecem suportar alguns distúrbios e viver um processo de sofrimento, no sentido utilizado por DEJOURS (1992).

Observa-se que o trabalho sob pressão foi bastante detalhado e várias referências a múltiplos aspectos críticos foram feitas que apontaram o estresse mental decorrente desta atividade.

"Há pressão de todo lado... da aviação, da chefia, das Normas, do sistema... além dos problemas financeiros, tenho problemas familiares graves. Se você não encontra uma válvula de escape, você começa a desmoronar."

Os conhecimentos em psicologia do trabalho (FAVERGE 1972; LEPLAT e CUNY 1977; PINSKI e col 1981) citados por VIDAL e MOREIRA (1999), consideram a conduta de um trabalhador em situação real de trabalho como resultado da interação entre o indivíduo e as condições de execução de tarefas. Outros estudos em Psicodinâmica do Trabalho reafirmam que a organização do trabalho encontra-se, em definitivo, sobredeterminada pelas relações sociais de trabalho. Os estudos mais divulgados desta corrente são os do grupo francês, que desenvolveu o campo teórico denominado Psicopatologia do Trabalho (DEJOURS 1992). Segundo DEJOURS (1996), as pesquisas destinadas a estudar estes processos devem ser de caráter eminentemente qualitativo.

"Já tive problemas de estômago, o meu intestino e a minha digestão estão péssimos... estou com uma endoscopia marcada. Tem dias que não consigo fazer uma refeição correta.... Tenho dor de cabeça, cansaço, tontura, nervosismo, ansiedade, tremores, taquicardia, azia, diarréia...A cada dia me sinto pior... Mas não posso parar".

As percepções destes trabalhadores sobre sua saúde indicam intensos níveis de auto-exigência e contribuem para que os próprios controladores participem na invisibilização do próprio mal-estar e do desgaste acarretados pelas atividades no 
controle de tráfego. Segundo SELIGMANN-SILVA (1997), "só ao longo do tempo seus agravos irão eclodir e, mais freqüentemente, sob expressão somática”.p. 102

"O cansaço fisico é inevitável. Este trabalho que você desenvolve aqui te exige 100\%. Você não pode errar. Da sua competência depende a vida de muitas pessoas. $O$ trabalho no controle de tráfego tem sido causa de vários problemas em minha saúde, pelas condições que se vive no dia-a-dia."

Tais agravos seriam o resultado de perdas, que configurariam um desgaste mental, no qual a fisiologia e o psiquismo são concomitantemente envolvidos por experiências em que se acumula a fadiga, ou em situações nas quais surgem emoções penosas, desdobrando-se estas alterações em repercussões sociais.(BERLINGER 1983; LAURELL 1989; SELIGMANN-SILVA 1993).

Como fator agravante de risco para a saúde destes trabalhadores, devem ser considerados os problemas ocupacionais enfrentados em conseqüência do trabalho em turnos e noturnos, que apontam a idade e o tempo de exposição a este regime de trabalho como variáveis que marcadamente influenciam os problemas de saúde (RUTENFRANZ e col 1985).

"A coisa que mais me angustia é a dificuldade que tenho para dormir... Mas morro de sono quando estou trabalhando... Esta situação me deixa muito estressado".

LUNA (1997) observou que a grande maioria dos controladores de tráfego aéreo nos EUA trabalha segundo um esquema de turnos de rápida rotação. Este sistema foi adotado por razões sociais. Os resultados proveitosos obtidos em termos de maior segurança na operação do sistema são fatores determinantes para que se limite o número de horas consecutivas nos plantões noturnos. Estes estudos foram iniciados com base em evidências de que os operadores estavam dormindo no trabalho, no turno da noite. Tanto informações objetivas como subjetivas indicam a queda da performance durante os turnos noturnos.

TANQUINI e col. (1986) observaram que o trabalho em turnos pode provocar, entre outras, uma mudança importante no sistema de secreção da gastrina e 
acidopepsina, causando dificuldades na digestão de certos alimentos ingeridos em determinados períodos do dia. MOREIRA e col (1999), suspeitam que a ansiedade seja a causa de os controladores ingerirem carboidratos em excesso durante a jornada laboral. Sua pesquisa no APP/RJ revelou o consumo de várias xícaras de café com açúcar, doces, bolos, biscoitos e pães, contribuindo para um sensível aumento nas taxas de triglicérides, naqueles trabalhadores.

"Tem dias que não consigo fazer uma refeição correta.... Tenho dor de cabeça, cansaço... A cada dia me sinto pior... Mas não posso parar. Se eu for afastado, eu saio da escala... e minha vida se complica ainda mais. Então vou levando... Este trabalho que você desenvolve aqui te exige 100\%. Você não pode errar. Da sua competência depende a vida de muitas pessoas."

A complexidade da vivência do controlador de tráfego aéreo com a sua realidade de trabalho, associada à dificuldade de descrever os agravos à saúde destes trabalhadores, fez com que DELL'ERBA (1994) adotasse a denominação de Síndrome do Burnout. Esta se caracteriza por sintomas de exaustão física, emocional e mental nos controladores de tráfego aéreo. Neste sentido, pesquisas têm revelado que a síndrome do Burnout está diretamente relacionada com a idade, com os anos de trabalho no tráfego aéreo, com a insatisfação profissional e com os fatores de estresse relacionados ao trabalho.

"Mas, quando você comete um erro... Aquilo fica te martelando. A gente se sente culpado. Mesmo que muitas vezes seja por falhas do próprio sistema. Esta parafernália toda é bonita, mas o sistema é falho!!!"”.

Revela-se, no discurso dos controladores, um sentimento de culpa que denota um sofrimento mental relativo à possibilidade de gravíssimo risco de catástrofe (DEJOURS 1995). Nesta situação, a responsabilidade pelo erro do operador pode ser considerada muito mais um problema colocado pela distância existente entre o trabalho prescrito e as atividades concretamente desenvolvidas (SELIGMANN-SILVA 1997). Este sofrimento mental pode ser amplificado pelo desconhecimento dos limites desta situação de perigo ou pela insegurança com relação aos métodos de controle, diante das dificuldades 
operacionais dos equipamentos. Tem-se, nesta realidade, um fator de penosidade. A situação de terem a responsabilidade pela vida de tantas pessoas e de, muitas vezes, sob pressão, serem obrigados ao descumprimento das normas de segurança, faz com que sejam tomados por ansiedade e estresse sobre lembranças do perigo mesmo inconsciente (DEJOURS 1992).

"Estou quase me aposentando e tenho queixas sobre perda de apetite, fadiga... O médico do HASP disse que são problemas psicossomáticos. Não sei o que é isto!! Só sei que, às vezes, depois de um "horário de pico" parece que não vou ter forças nem para chegar em casa".

Os efeitos cumulativos que potencializam as manifestações de distúrbios psicossomáticos, freqüentemente vêm acompanhados de distúrbios do sono. Relata-se a ocorrência de distúrbios na vida social e familiar considerados de significativa relevância para o bem-estar dos trabalhadores em turnos (FISHER 1994). Como assinala WALKER (1985), a influência dos fatores sociofamiliares se expressa nas freqüentes queixas dos trabalhadores em relação aos prejuízos causados por relativo isolamento social, discriminação de atividades e dificuldades em conciliar suas horas de folga com a de seus amigos e familiares.

"A questão do horário do controlador de vôo, é complicada, como todo o trabalhador que não tem uma hora certa, que trabalha à noite... Você tem a sensação de que alguma coisa sempre fica faltando na sua vida... Você não tem uma organização"

Os aspectos abordados neste discurso fazem parte do conjunto das representações sociais que os controladores de Tráfego Aéreo têm sobre sua saúde.

"Em determinadas horas eu fico " pau da vida”, num sufoco, numa agitação.... Mas, quase sempre consigo passar uma tranqüilidade, mesmo que por dentro eu esteja me remoendo. Mas, onde é que vou colocar para fora essa coisa toda?"

Fica explícito, neste discurso, até a preocupação que os controladores têm com relação a uma necessidade de adequação da carga de trabalho a uma melhor adequação 
da condição física individual. MOREIRA e col (1999), recomendam a adoção de um programa regular de atividades físicas não competitivas como uma maneira de aliviar o estresse cotidiano, desenvolver uma condição física compatível com a boa saúde, criar o hábito de movimentar todos os segmentos corporais com mais regularidade e prevenir os problemas que costumam acometer os trabalhadores de regimes sedentários.

Registra-se que o Sistema de Saúde da Aeronáutica, responsável pelo controle sistemático e periódico do controlador de tráfego aéreo, objeto desta pesquisa, é possivelmente detentor de um precioso acervo sobre a saúde dos aeronautas. Isso significa que a sistematização dos arquivos desse serviço, suas fichas e prontuários, poderiam constituir-se em importante material para o desenvolvimento de estudos epidemiológicos sobre às doenças profissionais mais prevalentes nestas categorias. Inicialmente, pretendia-se, neste estudo analisar esse acervo, no entanto, o acesso não foi permitido. 


\begin{tabular}{|l|l|l|}
\hline \multicolumn{2}{|c|}{ AS RELAÇÕES DO CONTROLADOR DE TRÁFEGO AÉREO COM A HIERARQUIA MILITAR. } \\
\hline \multicolumn{1}{|c|}{ IDÉIA CENTRAL } & \multicolumn{1}{|c|}{ EXPRESSÕES-CHAVE } & \multicolumn{1}{c|}{ DISCURSO Do SUJEITO COLETIVO } \\
\hline $\begin{array}{l}\text { O Controlador de } \\
\text { Tráfego Aéreo não } \\
\text { passa de um Sargento } \\
\text { submetido à hierarquia } \\
\text { militar. }\end{array}$ & $\begin{array}{l}\text { Atualmente falta respeito } \\
\text { humano... Falta respeito com a } \\
\text { profissão... Considero que esse } \\
\text { tratamento que é dado ao } \\
\text { controlador de tráfego se deva à } \\
\text { questão da hierarquia militar. }\end{array}$ & $\begin{array}{l}\text { Atualmente falta respeito humano... falta respeito com a profissão... Não } \\
\text { somos tratados como profissionais capazes e competentes. Considero } \\
\text { que esse tratamento que é dado ao controlador de tráfego se deva à } \\
\text { questão da hierarquia militar. Se eu abro minha boca para mostrar } \\
\text { alguma situação que, no meu ponto de vista, é errada... para alguém, que } \\
\text { em alguns casos não tem nem condições de estar ali chefiando aquele } \\
\text { órgão de controle... esse alguém, chega para mim, me dá um “cala a } \\
\text { boca", me ameaçando de prisão. E daí? Eu gostaria de progredir como } \\
\text { controlador de vôo... No entanto, mesmo sendo militar, para que eu } \\
\text { exerça um cargo de chefia no controle de tráfego eu teria que prestar um } \\
\text { concurso para ser oficial. Como Controlador de Tráfego Aéreo você } \\
\text { precisa ter liberdade de opinião para fazer com que seu trabalho } \\
\text { melhore... Você tem que mostrar onde estão os erros, mas quem fala } \\
\text { onde está o problema geralmente são pessoas que não estão ligadas ao } \\
\text { serviço do controle... Eles mudaram os equipamentos... Só que ninguém } \\
\text { perguntou para nós.... Agora por questões administrativas eles não têm } \\
\text { como remunerar um controlador de vôo de forma correta, por quê? } \\
\text { Porque eu não sou controlador de vôo, eu sou um Sargento. }\end{array}$ \\
\hline
\end{tabular}


O DSC, que expõe a relação hierárquico-militar existente no Controle de Tráfego Aéreo, constitui um vasto material que permite uma ampla análise de conjuntura desta realidade institucional. Este discurso é revelador de um sentimento de impotência destes trabalhadores, diante do sistema. O Controlador de Tráfego Aéreo não passa de um Sargento submetido à hierarquia militar.

"Atualmente falta respeito humano... falta respeito
com a profissão... Não somos tratados como
profissionais capazes e competentes. Como parte
desta corporação, considero que esse tratamento que
é dado ao controlador de tráfego aéreo aqui no Brasil,
se deva à questão da hierarquia militar."

Destaca-se a necessidade de aprofundamento desta importante discussão que, de fato, tem como questão a natureza de uma administração militar, fechada ao controle social, sobre um setor estratégico para o País. Por outro lado, o DSC aponta para a necessidade de investimentos no desenvolvimento técnico-científico, que permitam garantir maior confiabilidade ao sistema de vigilância no controle de tráfego aéreo. Este setor deve ser priorizado diante do real risco de acidentes de proporções catastróficas. (PORTO e FREITAS 1977)

"Se eu abro minha boca para mostrar alguma
situação que no meu ponto de vista é errada... para
alguém, que em alguns casos não tem nem condições
de estar ali chefiando aquele órgão de controle... esse
alguém chega para mim, me dá um "cala a boca", me
ameaçando de prisão. E daí?"

$\mathrm{Na}$ verdade, o que se explicita na fala dos controladores de tráfego aéreo é o fato desses profissionais estarem distantes do acesso às informações sobre projetos organizacionais e sobre o planejamento, em que a participação em decisões administrativas fica restrita aos altos postos da hierarquia militar. (SELIGMANNSILVA 1977).

O comando militar, por princípio, não considera as percepções daqueles que se encontram expostos aos riscos: os trabalhadores. E não percebem que a verdadeira prevenção de acidentes só surte efeito se houver uma disposição para se repensar o 
próprio processo administrativo, em suas instâncias mais elevadas (SCHMITZ e CARVALHO 1988).

No atual contexto, esta realidade interna ao Sistema de Controle de Tráfego Aéreo torna-se mais crítica diante da conjuntura sociopolitico-econômica de absoluta competitividade no setor do transporte aéreo. O DSC fala sobre a falta de investimentos em formação e sobre a não socialização de informações referentes à implantação de novas tecnologias no setor.

"Como Controlador de Tráfego Aéreo você precisa ter liberdade de opinião para fazer com que seu trabalho melhore... Você tem que mostrar onde estão os erros, mas quem fala onde está o problema geralmente são pessoas que não estão ligadas ao serviço do controle... Eles mudaram os equipamentos... Só que ninguém perguntou para nós...."

Nesta realidade, para além dos gastos na compra e instalação de equipamentos, aponta-se a inexistência de um fluxo de informações entre o topo e a base da pirâmide hierárquica.

"Eles mudaram os equipamentos... Só que ninguém perguntou para nós.... Agora por questões administrativas eles não têm como remunerar um controlador de vôo de forma correta, por quê? Porque eu não sou controlador de vôo, eu sou um Sargento".

Entende-se que as mudanças necessárias são de ordem política. Somente a prática do diálogo entre os atores sociais: trabalhadores, administradores, usuários e cidadãos, poderá promover o controle social do risco. Este processo assume uma relevância fundamental, por tratar-se de um processo decisório, que tem dimensão sobre a segurança e a vida de milhares de pessoas. (VIDAL e MOREIRA 1999) (PORTO e FREITAS 1997) 


\begin{tabular}{|l|l|l|}
\hline \multicolumn{2}{|c|}{ AS RELAÇÕES DO CONTROLADOR DE TRÁFEGO AÉREO COM A HIERARQUIA MILITAR. } \\
\hline \multicolumn{1}{|c|}{ IDÉIA CENTRAL } & \multicolumn{1}{|c|}{ EXPRESSÕES-CHAVE } & \multicolumn{1}{c|}{ DISCURSO Do SUJEITO COLETIVO } \\
\hline $\begin{array}{l}\text { O controlador civil é } \\
\text { marginalizado dentro de } \\
\text { contexto já difícil para os } \\
\text { próprios militares. }\end{array}$ & $\begin{array}{l}\text { O pessoal civil cada vez tem } \\
\text { menos chances... Não existe } \\
\text { oportunidade. Aqui se morre } \\
\text { como controlador de tráfego } \\
\text { aéreo. }\end{array}$ & $\begin{array}{l}\text { Hoje... para quem não tem curso superior... o salário que é pago para o } \\
\text { militar é um privilégio. Isso sem contar os benefícios com moradia e } \\
\text { direito de uso do hospital para a família. Outra vantagem para os } \\
\text { militares é que o tempo de serviço começa a contar lá da escola. Então, } \\
\text { com quarenta e poucos anos eles se aposentam, no auge do } \\
\text { conhecimento, da maturidade profissional. Ainda tem licença especial, } \\
\text { etapa alimentação, diária disto e daquilo. Para o civil é muito diferente, } \\
\text { administrativamente sou funcionário público, mas não tenho uma } \\
\text { carreira definida. Pode chegar a esse ponto? Promoção não existe. Os } \\
\text { mais antigos são indicados a ser chefe de equipe, só que em termos de } \\
\text { dinheiro nada!... Não existe oportunidade. Aqui se morre como } \\
\text { controlador de tráfego aéreo. Eu poderia conhecer muito mais desde que } \\
\text { me passassem informações que são de âmbito internacional. Na área de } \\
\text { controle de tráfego aéreo não existe uma escola a nível superior. Esta } \\
\text { parte fica toda para os militares que são treinados, mas depois aprendem } \\
\text { conosco... o tipo de trabalho na prática. Outra discriminação com o civil } \\
\text { é que eu não tenho direito ao atendimento no HASP, mesmo no caso de } \\
\text { doença relacionada ao trabalho. Eu pago um plano de saúde também, } \\
\text { porque o governo não me dá condições de freqüentar um hospital } \\
\text { público. O pessoal civil cada vez tem menos chances.... Fica aquele } \\
\text { desânimo cada vez maior de uma pessoa que foi o que a vida levou. }\end{array}$ \\
\hline
\end{tabular}




\section{O controlador civil é marginalizado dentro de um contexto já difícil para} os próprios militares. As representações sociais manifestadas no DSC dos civis indicam a existência de um contexto fragmentado que parece favorecer o militar.

É interessante notar que a integração entre colegas de trabalho é descrita por todos como boa, a diferença entre as categorias militares e civis não é apontada como problema, apesar das diferenças em termos de benefícios para os militares, que tornam a atividade do controlador militar "mais vantajosa."

"Hoje... para quem não tem curso superior... o salário
que é pago ao militar é um privilégio. Isso sem contar
os beneficios com moradia e direito de uso do hospital
para a família. Outra vantagem para os militares é
que o tempo de serviço começa a contar lá da escola.
Então, com quarenta e poucos anos, eles se
aposentam, no auge do conhecimento, da maturidade
profissional. Ainda tem licença especial, etapa
alimentação, diária disto e daquilo."

Segundo informações obtidas em entrevistas com operadores e supervisores mais antigos, a presença de controladores civis no controle de tráfego aéreo atende a uma determinação da OACI. Esta medida visa garantir uma representação de, pelo menos, $10 \%$ de trabalhadores civis no Controle de Tráfego Aéreo, em países onde a aviação civil estiver sob comando militar, e este é o caso do Brasil. Observou-se inexistência de um plano de carreira para os civis. Para os militares, as perspectivas em termos de carreira também não são favoráveis, uma vez que a promoção militar na aeronáutica privilegia a carreira do aviador.

"Para o civil, é muito diferente, administrativamente sou funcionário público, mas não tenho uma carreira definida. Pode chegar a esse ponto? Promoção não existe. Os mais antigos são indicados a serem chefe de equipe, só que em termos de dinheiro, nada!... Não existe oportunidade. Aqui se morre como controlador de tráfego aéreo."

Este estudo permitiu verificar que o Sistema Integrado de Segurança e Controle do Espaço Aéreo Brasileiro (SISCEAB), que integra as duas vertentes usuárias: aviação 
civil e militar, tem um modelo único de gestão do tráfego aéreo no Continente das Américas. Esta informação foi reconfirmada por diversas fontes, tais como, sindicatos e instituições de classe, e ainda, profissionais da área, já que não foi possível encontrar estes dados em fontes oficias. O controle de tráfego aéreo da aviação civil norte americana é administrado pelo Federal Aviation Administration - FAA, um órgão normalizador e regulamentador, que, por sua vez, responde ao Departamento de Defesa dos Estados Unidos - DOT, diretamente subordinado à presidência da república. Já o sistema canadense tem o gerenciamento do tráfego aéreo da aviação civil administrado por organização privada, aberta a amplo controle social.

"Outra discriminação com o civil é que eu não tenho
direito ao atendimento no HASP, mesmo no caso de
doença relacionada ao trabalho. Eu pago um plano de
saúde também, porque o governo não me dá condições
de freqüentar um hospital público. O pessoal civil
cada vez tem menos chances... Fica aquele desânimo
cada vez maior de uma pessoa que foi o que a vida
levou."

Na realidade, apesar das Normas de Controle e Inspeção de Saúde preconizadas no Anexo II da Organização Internacional da Aviação Civil (OACI), e do discurso presente na fala dos responsáveis pelo Serviço Médico da Aeronáutica: "por exercerem uma profissão onde não estar doente é motivo de segurança de vôo”, constata-se o uso privativo dos trabalhadores militares do serviço médico do Hospital da Aeronáutica de São Paulo - HASP. Esta situação se torna mais grave, na medida em que, nos casos em que os civis apresentam necessidade de afastamento da função por doenças relacionadas ao trabalho, o seguimento clínico do controlador de tráfego civil corre por sua conta. $\mathrm{O}$ militar conta com uma retaguarda específica dentro da estrutura corporativa. O civil simplesmente recebe o resultado do exame com o diagnóstico, não sendo permitido o seu atendimento no serviço de retaguarda da corporação aeronáutica. Esta situação constitui-se num problema, diante da necessidade de suporte psicológico especializado para enfrentar as inúmeras situações de trabalho que provocam estresse; o custo de um acompanhamento psicoterâpeutico particular é impraticável e não é coberto pela maioria dos planos de assistência médica, também custeados pelo próprio trabalhador. 


\begin{tabular}{|c|c|c|}
\hline \multicolumn{3}{|c|}{ RUMOS POSSÍVEIS NA REALIDADE DE TRABALHO DO CONTROLE DE TRÁFEGO AÉREO. } \\
\hline IDÉIA CENTRAL & EXPRESSÕES-CHAVE & Discurso do SuJeito Coletivo \\
\hline $\begin{array}{l}\text { É público e notório o interesse } \\
\text { aeronáutica no Controle de Tráf } \\
\text { Aéreo. }\end{array}$ & $\begin{array}{l}\text { Eu tenho esperança de que haja } \\
\text { mudanças. Mas se vê que a } \\
\text { aeronáutica não quer abrir mão } \\
\text { do controle de tráfego aéreo. }\end{array}$ & $\begin{array}{l}\text { Vê-se que a aeronáutica não quer abrir mão do controle de } \\
\text { tráfego, falam de criar a Agência Nacional de Aviação Civil, eles } \\
\text { até concordam, mas o controle de tráfego aéreo tem que ser deles! } \\
\text { Como se explica que o Departamento de Aviação Civil fique } \\
\text { subordinado à área de controle militar? Será um problema político } \\
\text { ou econômico? Não existe nenhuma justificativa para um DAC } \\
\text { militar! É óbvio que existem grandes interesses financeiros e de } \\
\text { poder... O tráfego aéreo vai ficar com quem? Com os militares ou } \\
\text { com civis? Eu tenho esperança de que haja mudanças. Que esse } \\
\text { trabalho venha a ser de uma área civil, não porque o militar seja } \\
\text { ruim, não é isso. É que eu acho que a área militar tem que ser bem } \\
\text { específica. O que se vê na estrutura da INFRAERO, pode servir } \\
\text { como exemplo, de uma empresa privada, onde a influência militar } \\
\text { é limitada. Existe lá uma outra mentalidade onde a eficiência e o } \\
\text { profissionalismo são exigidos, muito embora a lógica hierárquica } \\
\text { ainda se mantenha em alguns aspectos. Quem manda lá são } \\
\text { militares reformados, mas eles têm que mostrar competência, se } \\
\text { não eles não se mantêm. São todos contratados pela CLT e o } \\
\text { poder da hierarquia é relativo. Os controladores que são de } \\
\text { responsabilidade da INFRAERO têm uma dinâmica diferente, } \\
\text { têm melhor condição de trabalho e um salário melhor. Se } \\
\text { houvesse um movimento geral... se virasse tudo administração } \\
\text { INFRAERO, a gente teria poder de fazer alguma coisa, pois } \\
\text { teríamos mais força. }\end{array}$ \\
\hline
\end{tabular}




\section{É público e notório o interesse da aeronáutica no Controle de Tráfego} Aéreo. O DSC aponta críticas, questionamentos ao sistema vigente no controle do espaço aéreo, além de sinalizar expectativas positivas com relação a mudanças neste setor .

\section{"Não existe nenhuma justificativa para um DAC militar! É óbvio que existem grandes interesses financeiros e de poder...".}

Sob este aspecto, a vinculação deste serviço à administração militar, por meio do Comando Maior da Aeronáutica, imprime a este setor estratégico, em termos de segurança para a sociedade e para a economia do País, uma disciplina militar prestante, usada a serviço de interesses empresarias, tendo sua valorização vinculada à garantia de continuidade perene de lucros (VIDAL e MOREIRA 1999).

Por outro lado, a postura centralizadora da administração militar, demasiadamente racional e burocratizada, parece perder de vista a importância do desenvolvimento técnico-científico deste setor. Segundo VIDAL e MOREIRA (1999, p.5) “...os administradores da aeronáutica parecem aceitar passivamente o 'desmanche' técnico-científico... dos sistemas de vigilância e controle de tráfego aéreo”.

Outro aspecto ainda, destacado pelos autores acima, parece pautar que a lógica do sistema atual é a da própria manutenção do "status quo" vigente, em que se garanta o funcionamento de um controle de tráfego aéreo que não gere greves, que permaneça invisível à arena pública, não alardeando a fragilidade do sistema, não criando, enfim, problemas políticos.

Constata-se, no DSC, que o domínio do sistema de controle do espaço aéreo confere à aeronáutica um poder hegemônico sobre a aviação civil e militar. Ficando explícito, ainda, que esta instituição não aceita a possibilidade de perda de poder.

Neste contexto, o controle de tráfego da Torre de Guarulhos, administrado pela Empresa Brasileira de Infra-estrutura Aeroportuária (INFRAERO), segundo o DSC, parece se diferenciar do controle militar em alguns aspectos administrativos, sendo 
especialmente ressaltado o quesito da exigência de profissionalismo no cumprimento das normas e da regulamentação. A experiência positiva na INFRAERO parece sinalizar que a privatização deste setor se constitui como um caminho importante.

Neste sentido, vale referir os resultados de um estudo sobre as condições de trabalho e segurança no controle de tráfego aéreo brasileiro, que destacou a operação do controle da Torre de Viracopos/ Guarulhos, como a que melhor cumpria as normas e regulamentação internacional, segundo informações obtidas em entrevista. Por se tratar de relatório confidencial, não foi possível ter acesso a maiores informações junto a fontes oficias. Sabe-se, no entanto, que esse trabalho foi realizado a partir da solicitação do FAA (órgão regulador Norte Americano), abrangendo, no Brasil, 12 unidades de controle de tráfego aéreo, em várias cidades brasileiras. (Revista Aero Magazine 1999 dez).

"O que se vê na estrutura da INFRAERO pode servir como exemplo... . de outra mentalidade onde eficiência e profissionalismo são exigidos.... São todos contratados pela CLT e o poder da hierarquia é relativo. Se houvesse um movimento geral... a gente teria poder de fazer alguma coisa, pois teríamos mais força".

A partir da instituição do Ministério da Defesa, estudos vêm sendo realizados no sentido da criação de uma Agência Nacional da Aviação Civil. A expectativa de mudança é referida no discurso.

"Vê-se que a aeronáutica não quer abrir mão do controle de tráfego, falam de criar a Agência Nacional de Aviação Civil, eles até concordam, mas o controle de tráfego aéreo tem que ser deles! Como se explica que o Departamento de Aviação Civil fique subordinado à área, de controle militar?" 
José Augusto Varanda ${ }^{11}$, Secretário de Organização Institucional do Ministério da Defesa, responsável pela condução dos estudos para a criação da ANAC, tem tornado público os seguintes aspectos:

“a nova estruturação do setor passará pela regulamentação que a Agência irá estabelecer";

“a partir de estudos mais aprofundados feitos por técnicos mais capacitados com grande conhecimento sobre o setor";

"e também haverá preocupação em atender o interesse do usuário".

No entanto, tem sido manifestado pelos trabalhadores da aviação, em diversos Fóruns da categoria ${ }^{12}$, a preocupação do setor diante da situação em que o acesso às discussões sobre a criação da ANAC tem sido vetado.

\footnotetext{
${ }^{11}$ Cf. Declaração à Revista Aero Magazine.nº 69, Fev 2000.

9 1Seminário sobre ANAC, pelo SNA, 28/01/200; Audiência com Ministro da Defesa e SNA e FNAA; 21/02/2000; Seminário Organizado pela Gazeta Mercantil: “A Modernização do Transporte Aéreo"; 16/03/2000; Reunião com Sec. Geral da Pres. da Republica; 16/03/2000, entre outros.
} 


\begin{tabular}{|c|c|c|}
\hline \multicolumn{3}{|c|}{ RUMOS POSSÍVEIS NA REALIDADE DE TRABALHO DO CONTROLE DE TRÁFEGO AÉREO. } \\
\hline IDÉIA CENTRAL & EXPRESSÕES-CHAVE & Discurso do SuJeito Coletivo \\
\hline $\begin{array}{l}\text { Qualquer mudança no controle } \\
\text { de tráfego aéreo requer avanços } \\
\text { na esfera da democracia. }\end{array}$ & $\begin{array}{l}\text { Onde não existe democracia, fa } \\
\text { de respeito pelas pessoas e pela } \\
\text { vida... Existe o lado das } \\
\text { companhias... Mas os maiores } \\
\text { interessados são os próprios } \\
\text { usuários. } \\
\\
\end{array}$ & $\begin{array}{l}\text { Não é só salário!!! Mas a organização em si através do envolvimento } \\
\text { da chefia. Eles querem que a gente trabalhe como se nós fossemos } \\
\text { militares, sem questionamentos. É preciso avançar do militarismo } \\
\text { para uma mentalidade democrática. Falta participação, apoio ou } \\
\text { incentivo a uma interação entre as pessoas que trabalham aqui, falta } \\
\text { respeito pela opinião das pessoas e pela vida. Existe o lado das } \\
\text { companhias aéreas. Existe uma questão financeira envolvida nisso } \\
\text { tudo. Na prática as companhias se ajeitam politicamente, mas } \\
\text { economicamente é aqui que elas sofrem... Uma maravilha } \\
\text { tecnológica como o Airbus } 319 \text { dá prejuízo... Se o meu serviço não é } \\
\text { bom... bastam vinte minutos em órbita. Existem aviões, existem } \\
\text { pessoas que movimentam fortunas e o prejuízo é só delas. Eu tenho } \\
\text { a impressão de que algumas pessoas já sabem, os donos de } \\
\text { companhias aéreas, diretores, enfim essas pessoas que são os } \\
\text { maiores prejudicados, porque nós trabalhamos, na verdade, pra eles. } \\
\text { Eles percebem que há algo errado no ar e que o serviço não é } \\
\text { condizente com a necessidade. Os maiores interessados são os } \\
\text { próprios usuários... Vai acabar partindo deles um movimento } \\
\text { importante quando observarem que o risco que eles correm é muito } \\
\text { grande. A aviação comercial brasileira é muito frágil e atualmente } \\
\text { atravessa o período de maior turbulência de toda a sua história. As } \\
\text { pessoas que andam de avião não devem estar iludidas. Os usuários } \\
\text { precisam, de forma consciente, defender a segurança do sistema. } \\
\text { Infelizmente, somente a ocorrência de acidentes de proporções } \\
\text { catastróficas sensibilizará a sociedade para a necessidade de } \\
\text { mudanças neste setor. }\end{array}$ \\
\hline
\end{tabular}




\section{Qualquer mudança no controle de tráfego aéreo requer avanços na esfera da}

democracia. As representações sociais contidas no DSC sobre este tema expressam a diversidade do horizonte de pensamentos da cultura organizacional vigente sob a ótica militar.

"Não é só salário!!! Mas a organização, em si, através do envolvimento da chefia. Eles querem que a gente trabalhe como se nós fôssemos militares, sem questionamentos. É preciso avançar do militarismo para uma mentalidade democrática."

Foi possível apreender alguns efeitos da cultura militar sobre o trabalho complexo dentro do controle de tráfego. Na prática, o que ocorre é uma dificuldade enorme em se produzir qualquer alteração na sistemática administrativa imposta por este sistema.

\section{"Falta participação, apoio ou incentivo a uma interação entre as pessoas que trabalham aqui, falta respeito pela opinião das pessoas e pela vida."}

A falta de 'liberdade do pensar' e a falta de incentivo à participação em decisões administrativas comprometem o interesse pela atividade desenvolvida e pelos objetivos reais do trabalho (SELIGMANN-SILVA 1997). Esta situação contribui para manutenção de um cenário onde brilham vaidades pessoais daqueles que detêm o poder das decisões políticas. Este aspecto é bastante ressaltado no discurso.

“... Na prática as companhias se ajeitam politicamente, mas economicamente é aqui que elas sofrem... Eu tenho a impressão que algumas pessoas já sabem, os donos de companhias aéreas, diretores.... Eles percebem que há algo errado no ar e que o serviço não é condizente com a necessidade”.

Há de se considerar neste contexto, o interesse das empresas aéreas no perfeito funcionamento do controle de tráfego aéreo, especialmente no que diz respeito a aspectos econômicos, diretamente relacionados ao custo/consumo de combustível. Outros fatores, como comprometimento da "imagem da pontualidade", relacionada a toda a ordem de transtornos aos passageiros em virtude de atrasos nos vôos, até com perda de vôos de conexão, que acarretam mais prejuízos às companhias; potencialização 
dos riscos de acidentes em áreas terminais congestionadas, pagamento de taxas extras pelo uso do espaço aéreo, enfim, a eficiência do controle de tráfego aéreo é determinante para a sobrevivência econômica das empresas.

“Os maiores interessados são os próprios usuários... Vai acabar partindo deles um movimento importante, quando observarem que o risco que eles correm é muito grande.... As pessoas que andam de avião não devem estar iludidas. Os usuários precisam de forma consciente defender a segurança do sistema."

Pode-se detectar, neste discurso, a percepção do sujeito coletivo sobre a importância do controle social do risco. O usuário consumidor deste serviço é apontado como legítimo agente de transformação, a partir do conhecimento da realidade. $\mathrm{O}$ controlador parece sentir-se impotente no desencadeamento de uma ação preventiva, já que esta iniciativa tem caráter político-admistrativo. Na ocorrência de uma falha, via de regra, o trabalhador é tratado como "faltoso" e, nesse caso, engendra-se a figura da falta profissional, resultado de "má" realização do ofício (VIDAL 1984). A conduta do ocultamento dos limites e incertezas das situações e eventos de risco representa a legitimação dos interesses vigentes e a exclusão social (PORTO e FREITAS 1997).

"Infelizmente, somente a ocorrência de acidentes de proporções catastróficas sensibilizará a sociedade para a necessidade de mudanças neste setor." 


\section{RUMOS POSSÍVEIS NA REALIDADE DE TRABALHO DO CONTROLE DE TRÁFEGO AÉREO.}

\begin{tabular}{|c|c|c|}
\hline IDÉIA CENTRAL & EXPRESSÕES-CHAVE & DisCURSO do SuJEITO COLETIVO \\
\hline $\begin{array}{l}\text { Há um descrédito na } \\
\text { privatização da aviação c }\end{array}$ & $\begin{array}{l}\text { O controlador não acredita que a } \\
\text { criação da ANAC traga } \\
\text { perspectivas de melhoria para a } \\
\text { qualidade do serviço e } \\
\text { benefícios para a sociedade. }\end{array}$ & $\begin{array}{l}\text { Não acredito que a criação de uma Agência Nacional da Aviação Civil } \\
\text { (ANAC) traga alguma perspectiva para a melhoria da qualidade do } \\
\text { serviço e para a sociedade. Acho que a criação desta agência pode } \\
\text { representar um risco de agravamento para uma situação já frágil. O } \\
\text { sistema de transporte é muito vulnerável à lógica da competitividade. }\end{array}$ \\
\hline
\end{tabular}


Há um descrédito na privatização da aviação civil. $O$ controlador não acredita que a criação de uma Agência Nacional de Aviação Civil traga perspectivas de melhoria para a qualidade do serviço e benefícios para a sociedade. Este discurso expressa a representação social hegemônica da instituição militar.

"Não acredito que a criação de uma Agência Nacional da Aviação Civil (ANAC) traga alguma perspectiva para a melhoria da qualidade do serviço e para a sociedade."

A discussão sobre este tema será precedida de uma reflexão de caráter metodológico. A idéia central contraditória expressa neste discurso tem também uma importância metodológica, na medida em que traz para o universo representacional deste coletivo, uma particularização que expressa uma diferente forma de pensar (BORDIEU 1990). No que diz respeito ao conteúdo discursivo, vale dizer que o cenário do transporte aéreo é susceptível a extrema competitividade nacional e mundial. A publicação de artigos sobre a globalização da aviação, envolvendo questões sobre “desregulamentação" e "política de céu aberto", tem apontado alguns aspectos preocupantes para a sobrevivência da aviação comercial brasileira, considerando mais especificamente o lado do trabalhador.

Sem a intenção de justificar este "contraditório", adiciona-se a esta discussão alguns elementos de caráter informativo circunstancial, que estão presentes na realidade cotidiana desta categoria profissional, que se mostrou diferencialmente politizada em suas falas. Realmente, neste sentido, ficou presente, em conversas informais com os trabalhadores, uma certa apreensão com relação ao futuro do transporte aéreo no Brasil e a preocupação com estratégias para o enfrentamento da crise na aviação.

"Acho que a criação desta agência pode representar um risco de agravamento para uma situação já frágil. O sistema de transporte é muito vulnerável à lógica da competitividade."

De acordo com informações que vêm sendo publicadas na impressa em geral, existem fortes indícios de que o setor do transporte aéreo nacional não está preparado 
para enfrentar a competitividade nestes tempos de globalização (Folha de São Paulo 1999). Neste sentido, aponta-se a vulnerabilidade do transporte aéreo diante da política de "céus abertos" como uma questão que deve ser considerada neste cenário de incertezas para o trabalhador.

No que se refere a esta incerteza, cita-se a pesquisa sobre o impacto das práticas de racionalização e desenvolvimento tecnológico que vem condicionando riscos para a saúde dos trabalhadores (MATTOSO 1995). 


\begin{tabular}{|c|c|c|}
\hline \multicolumn{3}{|c|}{ RUMOS POSSÍVEIS NA REALIDADE DE TRABALHO DO CONTROLE DE TRÁFEGO AÉREO. } \\
\hline IDÉIA CENTRAL & EXPRESSÕES-CHAVE & DISCURSO dO SUJEITO COLETIVO \\
\hline $\begin{array}{l}\text { Somente uma decisão política p } \\
\text { modificar a situação de risco no } \\
\text { controle de tráfego aéreo. }\end{array}$ & $\begin{array}{l}\text { Regulamentação da } \\
\text { profissão... Investimentos em } \\
\text { formação e aperfeiçoamento e } \\
\text { agilidade administrativa. }\end{array}$ & $\begin{array}{l}\text { A política da aeronáutica sacrifica os seus funcionários e prejudica muito o } \\
\text { serviço de tráfego aéreo... Porque existe um sistema vinculado à hierarquia } \\
\text { militar. Para que o controlador de vôo exerça sua atividade de forma completa, } \\
\text { o primeiro passo será lutar para que a profissão de Controlador de Tráfego } \\
\text { Aéreo seja uma profissão regulamentada. A Organização Internacional da } \\
\text { Aviação Civil (OACI) determina padrões para o treinamento e formação do } \\
\text { controlador de tráfego aéreo. No entanto, o que se observa na realidade é que a } \\
\text { cada dia você tem uma mão-de-obra mal formada, mal treinada e mal } \\
\text { aperfeiçoada... Aí eles falam: você vai ter que começar a dar instrução para o } \\
\text { pessoal mais novo! Na realidade, nunca houve uma programação para receber } \\
\text { o controlador estagiário. Ele chega e aí? O que faz com ele? Os novos não } \\
\text { estão pegando essa paixão, porque não estão dando chance pra eles. Aqui, } \\
\text { nunca houve uma programação para receber o controlador estagiário. Eu, } \\
\text { tristemente, vejo que as pessoas apaixonadas pelo serviço estão indo embora. } \\
\text { São as pessoas que de uma certa forma "carregam o piano"... E isso vai trazer } \\
\text { problemas. Não existe uma infra-estrutura de treinamento. A própria chefia, } \\
\text { deveria ser auxiliada na parte administrativa por um controlador experiente. } \\
\text { Poderia ter um certo rodízio entre os próprios controladores. A experiência de } \\
\text { conhecer o outro lado seria interessante para ele... Algumas das situações no } \\
\text { APP-SP são inaceitáveis... A maioria dos colegas mal dá conta da fraseologia } \\
\text { básica em inglês! Existe controlador que nunca fez um vôo de cabine! E ele } \\
\text { está dando instrução para o comandante, mas não sabe o que se passa na } \\
\text { aeronave... As empresas são as primeiras a reconhecer a necessidade de uma } \\
\text { maior interação entre o trabalho dos controladores e dos pilotos. Mas, na } \\
\text { verdade, o que falta é a agilidade administrativa e menos burocracia. }\end{array}$ \\
\hline
\end{tabular}


Somente uma decisão política poderá modificar a situação de risco no controle de tráfego aéreo. No discurso dos trabalhadores, três pontos são levantados: regulamentação da profissão, investimentos em formação $e$ aperfeiçoamento e maior agilidade administrativa.

"A política da aeronáutica sacrifica os seus funcionários e prejudica muito o serviço de tráfego aéreo... Para que o controlador de vôo exerça sua atividade de forma completa, o primeiro passo será lutar para que a profissão de Controlador de Tráfego Aéreo seja uma profissão regulamentada".

No que diz respeito à regulamentação da profissão de controlador de tráfego aéreo, vale resgatar que o projeto de Lei $n^{\circ} 188$ de 1986, com esta disposição, foi apresentado ao Congresso Nacional pelo Senador Nelson Carneiro. Segundo relato da direção do Sindicato Nacional dos Trabalhadores da Proteção ao Vôo, a apresentação deste projeto tem um valor histórico, tendo sido à época mobilizador de um número significativo de trabalhadores da proteção ao vôo, que não conseguiu, entretanto, constituir-se em massa crítica com poder de pressão para a aprovação do projeto.

Com relação aos investimentos em formação e treinamento para o trabalho no controle de tráfego aéreo, foram constadas deficiências no treinamento que trazem à tona questões relevantes, e que apontam a necessidade urgente na busca de soluções.

“A Organização Internacional da Aviação Civil (OACI) determina padrões para o treinamento e formação do controlador de tráfego aéreo. No entanto, o que se observa na realidade é que a cada dia você tem uma mão-de-obra mal formada, mal treinada e mal aperfeiçoada..."

De fato, a capacidade de gerenciamento do espaço aéreo é uma função direta da organização do trabalho dos controladores e da formação adequada destes profissionais. Não se trata somente de uma questão de quantidade. O controle exige uma completa interação entre os profissionais. O número destes também deverá ter um patamar ideal, a partir do qual a qualidade da interação passará a ser prejudicada. Por isso, tão importante quanto a quantidade de controladores em termos absolutos aspectos como a formação técnica, a experiência prática e as condições físicas 
relacionadas aos hábitos de vida, além da aptidão real individual para suportar a carga de trabalho, devem ser considerados (VIDAL e MOREIRA 1999). De acordo com a opinião dos operadores, este problema pode ser equacionado sem a necessidade de recorrer-se a recursos tecnológicos sofisticados, mas, sim, a decisões político-administrativas centradas no controlador.

\section{"Na realidade, nunca houve uma programação para receber o controlador estagiário. Ele chega, e ai? O que faz com ele?".}

No entanto, por necessidade de serviço, o que tem ocorrido é o ingresso de operadores, recém-homologados ou em estágio de observação, precocemente lançados na operação. E/ ou o recurso administrativo de transferência de pessoal de outros estados. As duas situações, segundo foi possível perceber nos depoimentos, são geradoras de cargas adicionais de estresse, causadoras de revolta e descontentamento destes trabalhadores.

\section{"Existe controlador que nunca fez um vôo de cabine! E ele está dando instrução para o comandante, mas não sabe o que se passa na aeronave".}

Outra dificuldade apontada pelos operadores mais antigos foi a falta de conhecimento das novas características operacionais das aeronaves. Este problema tem sido causa de orientações contraditórias, que muitas vezes não podem ser cumpridas pelos pilotos, evidenciando o desconhecimento técnico dos controladores, o que influencia negativamente a relação de credibilidade entre esses profisssionais.

Avalia-se que se os níveis de segurança têm se mantido bons, muito se deve a uma superação constante das dificuldades de trabalho por parte dos controladores e dos pilotos brasileiros (VIDAL e MOREIRA 1999).

Fica evidente que as questões presentes no DSC expressam sobretudo a enorme dificuldade em se produzir qualquer alteração na sistemática administrativa do controle de tráfego aéreo. Aponta-se que qualquer mudança neste contexto passa pelo reconhecimento das aptidões e esforços do trabalhador. Ele espera uma reciprocidade em termos de confiança, em forma de respeito humano. Acredita-se que mudanças na filosofia de trabalho só acontecerão a partir de iniciativas de cunho político-administrativo abertas à participação dos trabalhadores em projetos organizacionais, assim como, em processos decisórios sobre todas as questões que lhes dizem respeito. 


\section{CONSIDERAÇÕES FINAIS}

Com o presente estudo buscou-se verificar a relação entre processo saúdedoença-trabalho e determinações sociais junto aos trabalhadores do Centro de Controle de Tráfego Aéreo, localizado no Aeroporto de Congonhas em São Paulo. Como objetivo mais específico, procurou-se apresentar alguns subsídios que possam vir a favorecer a implementação de práticas de promoção e proteção da saúde e de segurança na aviação.

A busca de tal conhecimento orientou-se por um olhar de investigação que diferencia o presente trabalho de outros na área, uma vez que se baseou em uma metodologia de pesquisa que possibilitou trazer para análise as formas como os próprios trabalhadores percebem as repercussões das condições de seu trabalho sobre a saúde.

Por meio da metodologia do Discurso do Sujeito Coletivo - DSC e com embasamento na Teoria das Representações Sociais, foram definidos alguns indicadores que permitiram ao pesquisador compreender o significado que esses trabalhadores atribuíam ao seu trabalho, à sua saúde, assim como conhecer a percepção que esses operadores tinham sobre as normas de segurança em saúde preconizadas pelo Comando Maior da Aeronáutica.

Acredita-se que, para qualquer intervenção técnica que possa vir a favorecer a implementação de práticas de promoção e proteção da saúde e de segurança na aviação, deve-se conhecer o significado que o trabalhador atribui ao seu trabalho.

Neste sentido, a análise dos discursos realizada proporcionou vários elementos elucidativos, gerando, assim, um volume de material rico para a busca de uma melhor compreensão das representações sociais dos controladores de tráfego aéreo sobre sua saúde e sobre as práticas de saúde na corporação da aeronáutica.

Constatou-se que o controlador de tráfego aéreo é um "tomador de decisão". A representação social que estes operadores têm da própria profissão corresponde à imagem de pessoas especiais, que têm sob seu controle a ponta da linha do sistema, que questionam o mito da confiabilidade absoluta e apontam com clareza falhas e problemas. Sua atuação difere de um operador especializado de outras indústrias modernas que, a rigor, pode ser substituída por um sistema "robotizado". Até onde se 
sabe, ao menos na atualidade, os sistemas automatizados só são seguros se contam com o homem como última proteção em caso de pane sistêmica. Neste sentido, aponta-se como risco da automação, a supressão do homem na condução manual do sistema, a perda dos referenciais reguladores do risco e sua eficácia como último sustentáculo em casos de situação fora de controle. Portanto, a importância de se dedicar ao estudo dos fatores humanos a mesma ênfase comumente empregada no desenvolvimento tecnológico.

Nesta perspectiva, a abordagem metodológica utilizada - DSC, por meio de um processo de investigação direta, permitiu alcançar os objetivos do presente estudo, possibilitou apreender a compreensão que os trabalhadores têm de seu universo de trabalho e conhecer o cotidiano de vida destes controladores - suas condições de trabalho e o desgaste a que estão submetidos -, e ainda, criou um espaço em que o trabalhador pôde expressar as suas percepções com relação às possíveis formas de melhoria da qualidade de vida no trabalho.

Os principais achados deste estudo podem ser apresentados em temas como: a representação social do controlador de tráfego aéreo sobre o seu trabalho, sua experiência com o risco, as práticas de saúde da instituição e a relação com a hierarquia militar. Será apresentada também uma síntese das reflexões dos trabalhadores sobre a necessidade de implementação de práticas de promoção da saúde essenciais para a segurança da aviação. Dentre os diversos aspectos que envolvem a saúde e o trabalho, tornaram-se claras as percepções sobre sentimentos, capacidades, habilidades, mágoas, desesperanças, conhecimentos, experiências.

O trabalho é representado no discurso dos controladores de tráfego aéreo como prazeroso e fantástico. Essa representação ficou evidenciada no DSC desses trabalhadores de diferentes modos, em diferentes ocasiões. Entretanto, os operadores manifestaram também uma preocupação em relação à falsa modernidade de um sistema que consideram tecnologicamente desatualizado. As representações sociais deste coletivo sobre a automação dos processos trazem, assim, à tona dúvidas sobre o aparente avanço tecnológico e sobre a falta de confiabilidade no sistema.

As experiências com o risco foram expressas de forma contundente no DSC. A falta de confiabilidade do operador no sistema é por si só preocupante, assim o estresse deste trabalhador deve ser compreendido também como um fator de risco. 
A percepção dos riscos expressa nos DSC foi discutida neste estudo sob a ótica da dimensão ambiental e do controle social do risco. Revelou-se, nas representações sociais dos operadores, a expressão de preocupação, de responsabilidade e de impotência diante da rigidez da estrutura militar. O risco decorrente de acidentes no transporte não é uma questão restrita à saúde do trabalhador e deve ser considerado como um problema que envolve a sociedade contemporânea.

Dentro deste contexto de riscos, outro agravante mencionado é a dupla jornada de trabalho, percebida pelos trabalhadores como geradora de cansaço e fadiga, sendo incompatível com uma atividade que exige extrema atenção, precisão de raciocínio e agilidade intelectual. Constatou-se que a maioria dos operadores, além da atuação no controle de tráfego aéreo, que obedece ao sistema de turnos alternados, acumula outra atividade profissional.

Ao mesmo tempo, este trabalhador enfrenta ainda a ameaça permanente de ser culpabilizado pela ocorrência de acidentes. Esta concepção unicausal, que culpabiliza o operador, em nada contribui para a compreensão do problema em sua verdadeira amplitude.

Como saída que permite ao trabalhador lidar com esta situação, um aspecto bastante enfatizado no DSC é a solidariedade, o trabalho em equipe. O controlador afirma poder suportar o estresse de lidar com os diversos riscos graças ao grupo.

Neste contexto de trabalho, as representações sociais expressas no DSC revelam claramente a consciência destes profissionais sobre os riscos à saúde presentes na atividade que desempenham, sem contudo receber um acompanhamento adequado. Sobre as práticas de saúde institucionais, é preocupante constatar que o órgão responsável pelas "inspeções de saúde" e os médicos do HASP não conhecem a realidade de trabalho do controlador de tráfego aéreo. Na maioria das vezes, o trabalho do controlador é desconhecido, até pelos próprios médicos responsáveis pela inspeção de saúde realizada pelo Hospital da Aeronáutica de São Paulo - HASP.

O DSC expõe a relação hierárquico-militar existente no Controle de Tráfego Aéreo e constitui um vasto material que permite uma ampla análise de conjuntura desta realidade institucional. Os discursos revelam sentimentos de marginalização e 
impotência destes trabalhadores diante de um sistema fragmentado, que favorece o profissional militar.

Os controladores de tráfego aéreo expressam uma realidade vivida de riscos e agravos resultantes do trabalho sob pressão. Esses trabalhadores parecem criar formas para suportar o processo de sofrimento mental decorrente dessa situação.

O DSC mostra críticas, questionamentos ao sistema vigente no controle do espaço aéreo e sinaliza que qualquer mudança no controle de tráfego aéreo requer avanços na esfera da democracia. As representações sociais contidas no DSC sobre este tema expressam a diversidade do horizonte de pensamentos da cultura organizacional vigente sob a ótica militar. Foi possível apreender alguns efeitos da cultura militar sobre o trabalho complexo dentro do controle de tráfego. Na prática, o que ocorre é uma dificuldade enorme em se produzir qualquer alteração na sistemática administrativa imposta por este sistema.

A perspectiva de criação da Agência Nacional de Aviação Civil também não é vista como possibilidade de melhoria para a qualidade do serviço e benefícios para a sociedade.

O discurso dos trabalhadores evidencia a necessidade de decisão política que possa modificar a situação de risco no controle de tráfego aéreo. Três pontos são ressaltados: regulamentação da profissão, investimentos em formação e aperfeiçoamento e maior agilidade administrativa.

As representações sociais deste coletivo sobre a problemática existente no controle de tráfego aéreo foram expressas com clareza, sendo pertinente e legítima a preocupação e interesse desses trabalhadores pela realidade do controle de tráfego aéreo. Todos esses elementos trazem uma contribuição qualitativa, carregada de significados fundamentais às práticas no campo da Saúde do Trabalhador. A construção metodológica do discurso do sujeito coletivo, permitiu o acesso a uma cultura organizacional, qualitativamente diferenciada de uma "coletividade matemática", e que deve ser conhecida antes de qualquer intervenção no campo da Saúde do Trabalhador. Conhecer o domínio do operador sobre o sistema de vigilância do espaço aéreo e valorizar o saber sobre o seu trabalho constitui um passo importante e preliminar a qualquer processo decisório. 
A determinação da atividade de trabalho tem ligação evidenciável, por um lado, com elementos estruturais de controle social do risco, com mudanças de formas organizacionais, com concepções de tecnologia que incorporem o saber do trabalhador e, por outro, com formação e treinamento permanentes.

É inerente à Saúde do Trabalhador sua natureza interdisciplinar, de construção conjunta dos campos da Sociologia e da Antropologia do Trabalho, da Engenharia, Epidemiologia, da Psicologia Social, da Análise Ergonômica do Trabalho, entre outros, onde cada perspectiva seja não só capaz de dialogar uma com a outra, mas também de transformar-se através do diálogo entre elas e os atores sociais envolvidos, contribuindo para uma abordagem de (re) concepção global dos sistemas.

É importante salientar a dimensão social e ambiental do trabalho realizado pelo controlador de tráfego aéreo. Este fazer caracteriza-se como um risco potencial para a saúde pública, uma vez que a ocorrência de um acidente pode atingir proporções catastróficas para a sociedade. Estudos apontam que o número absoluto de acidentes graves, que hoje se situa na faixa de 25 a 30 por ano, deverá ultrapassar 50 por ano, atingindo a média de uma catástrofe por semana (VIDAL e MOREIRA 1999).

Neste contexto, o reconhecimento do importante papel dos controladores para a confiabilidade dos sistemas é imprescindível. São eles que tomam as decisões finais que conduzem a uma posição segura diante das perturbações. O desafio preventivo torna-se maior à medida que passa a exigir um diálogo permanente entre os profissionais das diversas áreas do saber, dos trabalhadores da aviação e da sociedade.

Portanto, no que diz respeito à dimensão ambiental, apontam-se os riscos para a sociedade e para o meio ambiente. Considera-se que o impacto ultrapassa o âmbito das condições de vida e saúde dos controladores, afetando também a saúde dos passageiros, a dos tripulantes, bem como a saúde nas cidades. Nessa preocupação com a qualidade de vida no trabalho e nas cidades, inscreve-se a proposta da Promoção da Saúde.

A Promoção da Saúde relaciona a determinação da saúde ao impacto das dimensões sociais, culturais, econômicas e políticas nas coletividades, visando 
alcançar um desenvolvimento social mais eqüitativo. Por outro lado, ressalta que a saúde não é assegurada apenas pelo setor da saúde, demandando uma ação coordenada entre diferentes setores sociais.

Como os riscos no sistema de controle de tráfego aéreo vêm afetando não só a qualidade de vida dos trabalhadores, mas também a de outros grupos sociais, apontase a necessidade de uma ampla ação intersetorial. Na busca de alternativas para melhoria da qualidade de vida, instituições da sociedade civil não governamentais, instituições governamentais envolvidas com as questões de saúde do trabalhador e meio ambiente, instituições representativas dos trabalhadores, seriam chamadas a debater os interesses da coletividade.

Por fim, neste estudo, estão delineados com clareza os argumentos daquele que conhece a fundo a questão: o trabalhador. Suas críticas, sugestões e soluções para melhoria da qualidade do trabalho, ora fundamentadas, não poderiam ser tão bem definidas como foram no próprio discurso do sujeito coletivo. 


\section{REFERÊNCIAS}

Adams J. Risk. Londres: UCL/Taylor \& Francis; 1995.

Adorno RCF, Castro AL. O exercício da sensibilidade: pesquisa qualitativa e a saúde como qualidade. Saúde e sociedade1994; 3(2): 172-85

Akerstedt, T Gilberg M. Sleep disturbances and shift work In: Reinberg A, Vieux N, Andlauer P, editors. Night and shift work, biological and social Oxford: Pergamon Press; 1981. p.127-37, (Advances in Biociences, 30).

Akerstedt T Gilberg M. Displacement of the sleep period and sleep deprivation: implications for shift work. Hum Neurobiol 1982; 1:163-71.

Akerstedt T, Torsvall L. Napping in the shift work. Sleep 1985; 8:105-9.

Akerstedt T. Sleepness as a consequence of shift work. Sleep 1988; 11:17-34.

Anderson RM, Bremer DA. Sleep duration at home and sleepness on the job in rotating twelve-hour shift workers. Hum Factors 1987; 29:477-81.

André MEDA. Texto, contexto e significados: algumas questões na análise de dados qualitativos. Cad Pesq. São Paulo; 1983; (45): 66-71.

Ayres JRCM. Sobre o risco: Para compreender a epidemiologia. São Paulo: Hucitec; 1997.

A Primeira voz clara. Aero Magazine 2000 (69): 44.

Babisch W Ising H Elwood PC Sharp DS Bainton D. Traffic noise and cardiovascular risk: the Caerphilly and Speedwell studies, second phase. Risk estimation, prevalence, and incidence of ischemic heart disease. Arch Environ Health 1993;Nov-Dec, 48(6):401-13.

Berlinguer G. A Saúde nas fábricas. São Paulo: Hucitec; 1983.

Berlinguer G. Reforma sanitária Itália Brasil.. São Paulo: Hucitec; 1988.

Bernardino MTSM. Lesões por Esforços Repetitivos - LER - a doença para o indivíduo. São Paulo; 1998. [Dissertação de Mestrado - Faculdade de Saúde Pública da USP].

Bertotto MS. Prevenção do câncer: porque sim, porque não. São Paulo; 1999. [Dissertação de Mestrado - Faculdade de Saúde Pública da USP].

Bonciani M. organizador. Saúde, ambiente e contrato coletivo de trabalho: experiências em negociações coletivas. São Paulo: LTr Editora; 1996.

Bjorkman M Ahrlin U Rylander R. Aircraft noise annoyance and average versus maximum noise levels. Arch Environ Health 1992; 47(5): 326-9.

Boudes N. Memory performance and diagnostic processes in air traffic control. In: Time and Space in Process Control: Proceeding of the "4th European Conference on Cognitive Science Approaches to Process Control. Baveno, Italy: Instituto di Psicologia Rome 1997. p. 204-8.

Bourdieu P. Coisas ditas. São Paulo: Brasiliense; 1990.

Bradbury JA. The policy implications of differing concepts of risks. Science, Technology and Human Values 1989; 14:380-399.

Braverman H. Trabalho e capital monopolista. $3^{\text {a }}$ ed. Rio de Janeiro: Guanabara; 1987. 
Brown FM. Sleep-nap behaviors of three permanent shifts of hospital nurses. In: Costa G, Cesana G, Kogi K, Wedderburn A, editors. Shiftwork: health, sleep and performance: Studies in industrial and organizational psychology 10. Frankfurt am Main. Peter Lang; 1990. p.173-78.

Bruno L. Educação e trabalho no capitalismo contemporâneo. São Paulo: Atlas; 1996.

Bunnage D. The consequences of shift work on social and family life. In: Wedderburn A \& Smith P, editors. Psychological approches to night and shift work.25p.(Seminar Paper no. 7), Edinburgh, Heriot-Watt University; 1984.

Câmara, VM.Galvão LAC. A patologia do trabalho numa perspectiva ambiental. In: Mendes R. organizador. Patologia do trabalho. Rio de Janeiro: Atheneu; 1995. Cap 24.

Carraro FL. Entre fogos cruzados: A criança de classe especial. São Paulo; 1999. [Dissertação de Mestrado - Faculdade de Saúde Pública da USP].

Castro Sá EN. O setor informal urbano: a organização e as condições de saúde de um grupo de vendedores ambulantes.São Paulo; 1998. [Tese de Doutorado- Faculdade de Saúde Pública da USP].

Chan OY. Sleepwake patterns and subjective sleep quality of day and night workers: interaction between napping and main sleep episodes. Sleep 1989;12:439-48.

Chen TJ, Chen SS. Effects of aircraft noise on hearing and auditory pathway function of. Int Arch Occup Environ Health 1993; 65(2): 107-11.

Chen TJ, Chen SS, Hsieh PY, Chiang HC. Auditory effects of aircraft noise on people. Arch Environ Health 1997; 52: 45-50.

Cipolla-Neto J, Marques N, Menna-BarretoLS. editores, Introdução ao estudo da cronobiologia. São Paulo: Ícone/EDUSP; 1988.

Cordeiro HK. Mondialisation de l'économie et restructuration de l'espace aérien brésilien dans la période post-70 [Paper apresentado no Symposium International UGI; 1993; Issy:Boulogne].

Costa G, Apostoli P, D’Andrea F, Gaffuri E . Gastrointestinal and neurotic disorders in textile shift workers. In: Reinberg A, Vieux N, Andlauer P, editors, Night and shift work: biological and social aspects. Oxford: Pergamon Press; 1981. p.215-21. (Advances in Biociences, 30).

Cruz C, Della Rocco P, Hackworth C. Effects of quickr oatating shift schedules on the health and adjustment of air traffic controllers. Aviat space environ med 2000 Apr; 71(4):400-7.

[DAC] Departamento de Aviação Civil [on line] http://www.dac.gov

.disponível no site em 11/03/2000.

Daniellou F Les nouvelles technologies. In: B. Cassou; organizador, Huez D Mousel ML Sptizer C Touranchet A. Les risques du travail. Paris: La Découverte; 1985, 99-111.

Dejours C. A Loucura do trabalho. $5^{\text {a }}$ ed. São Paulo: Cortez; 1992.

Dejours C. Uma nova visão do sofrimento humano. In: Chanlat, organizador. O indivíduo na organização. São Paulo: Atlas; 1996; 149-73.

Dell'Erba G, Venturi P, Rizzo F, Porcu S, Pancheri, P. Burnout and health status in Italian air traffic controllers. Aviat space environ med. 1994; 65:315-22.

Dempsey PS. Flying blind: The failure of airline desregulation. Washington(DC): Policy Institute; 1993. 
Dias EC. A atenção à saúde do trabalhador no setor saúde (SUS), no Brasil: realidade, fantasia ou utopia. Campinas; 1994. [Tese de doutorado da Faculdade de Ciências Médicas da UNICAMP].

Duclos D. L'homme face au risque technique. Paris: L'Harmattan; 1991.

Elias N. O processo civilizador. Rio de Janeiro: Jorge Zahar; 1993.

Elias N. Technization and civilization. Theory culture and society. 1995.12 (13): 7-42.

Faverge JM L. Homme agent de infiabilité et de fiabilité du processus industriel. Ergonomics Abstract. Paris; 1980; 13: 301-27.

Faverge JM. Les accidents du travail. In: Reuchlin M; organizador. Traité de psychologie du Travail. Travailleurs et systèmes techniques. Paris: PUF; 1972. v 3.

Ferreira LL. Voando com os pilotos: condições de trabalho dos pilotos de uma Empresa de Aviação Comercial.Assoc. Pilotos Varig, $2^{\text {a }}$ ed. São Paulo; 1998.

Ferreira LL Maciel RH, Paraguay AI. A construção da ergonomia. In: Rocha LE, Buschinelli JTP. Isto é trabalho de gente? Petrópolis: Vozes; 1994. Cap. 13

Ferreti CJ, Zibas DML, Madeira FR, Franco MLPB. Tecnologias, trabalho e educação Um debate multidisciplinar. Petrópolis: Vozes; 1994.

Fischer FM. Absenteísmo e acidentes de trabalho entre trabalhadores em turnos de indústria automobilística. São Paulo;1984. [Tese de Doutorado-Faculdade de Saúde Pública da USP.]

Fischer FM, Hofmeister VA, Scatena TC, Bruni AC. Reorganização do trabalho em turnos na companhia do metroplolitano de São Paulo. In: Congresso da Associação de Medicina do Trabalho; 1987; Florianópolis. v.2, p.667-92.

Fischer FM. Relatório de pesquisa sobre otimização do transporte de madeira pela utilização de princípios ergonômicos na organização do trabalho. São Paulo: FSP- USP; 1988.

Fischer FM. Jornadas de trabalho em horários irregulares. Contato 1990; (161):21-34.

Fischer FM, Paraguay AIBB. Relatório de pesquisa sobre condições de trabalho, organização do trabalho e suas repercussões sobre a vida dos trabalhadores em indústria petroquímica paulista. São Paulo: .FSP-USP; 1991.

Fischer FM. O trabalho do aeronauta: impactos sobre sua saúde. Estudo de caso de um piloto. Rev Cockpit 1994; (16):8-11.

Fischer FM, Lieber RR, Brown FM. Trabalho em turnos e as relações com a saúde-doença. In: Mendes R, organizador. Patologia do trabalho. Rio de Janeiro: Atheneu; 1995. Cap.21

Folkard S, Minors DS, Waterhouse JM. Chronobiology and shiftwork: current issues and trends. Chronobiology; 1985; 12:31-54.

Folkard S. Circadian performance rhythms: some practical and theoretical implications. Philos. Trans R Soc. Lond B Biol Sci 1990; 327:543-53.

Foret J, Benoit O. Étude du sommeil de travalleurs à horaries alternants: adaptation et récupération dans le cas de rotation rapide de poste (3-4 jours). Eur J Appl Physiol 1978;38:71-82.

Fortes PAC. Reflexões sobre a bioética e o consentimento esclarecido. Bioética.1994; 2: $129-135$. 
Frese M Harwich C. Shiftwork and the lenght and quality of sleep. J Occup Med 1984; 26:561-6.

Gadbois C. Women on night shift: interdependence of sleep and off - the - job activities. In: Reinberg A, Vieux N, Andlauer P, editors. Night and shift work: biological and social aspects. Oxford: Pergamon Press; 1982.

Gillberg M Alkerstdt T. Possible measures of sleepness for the evaluation of disturbed and displaced sleep. In: Reinberg A, Vieux. N, Andlauer P, editors. Night and shift work: biological and social aspects. Oxford: Pergamon Press;1981. p.155-60.

Green KB Pasternack BS Shore RE. Effects of aircraft noise on hearing ability of schoolage children. Arch Environ Health; 1982; 37(5):284-9.

Guérin FM. Activité et charge de travail. In: B. Cassou; organizador, Huez D Mousel ML Sptizer C Touranchet A. Les risques du travail. Paris: La Découverte; 1985, 68-75.

Halberg F Caradente F Cornelissen G Katinas GS. Glossary of Chronobiology. Chronobiologia. 1977; 4 Suppl, 1: 1-189.

Hopkin VD. Air Traffic Control. In: Wiener EL Nagel DC. Human factors in aviation. New York: Academic Press; 1988. p.639-63.

Hopkin VD. Human factors in air traffic control. London: Taylor \& Francis; 1995.

Isaac AR. Situacional awareness in air traffic control: human coghition and advanced technology. In: Harris D, organization. Engeenering psychology and cognitive ergonomics. Aldershot, Hampshire: Ashgate Publishing; 1997. v1:Transportation systems.

Itani A. Relatório de pesquisa sobre as condições de trabalho e saúde do controlador de tráfego aéreo. Unesp- Instituto de Biociências-Rio Claro, 1999.

Itani A. Trabalho e saúde nos transportes: entre o invisível e o risco. São Paulo: Hucitec; 1998.

Itani A. O trabalho, sua invisibilidade e seu estudo: algumas considerações a partir do trabalho nos serviços dos transportes. Tempo Social; Revista Sociologia, USP, São Paulo; 1996a; 8(1): 162-94.

Itani A. A invisibilidade dos riscos nos transportes. Contato 1996 b; (175):62-68.

Jansen B: Le travail human. Paris; PUF; 1990.

Jardim S. Processo de trabalho e sofrimento psíquico: O caso dos pilotos do Metrô Carioca. Rio de Janeiro; 1994. [Tese de Doutorado - Instituto de Psiquiatria - Universidade Federal do Rio de Janeiro].

Jodelet D. Représentation sociales: un domaine en expansion. In: Jodelet D. organizador. Des représentations sociales. Paris; PUF; 1989.

Kalimo R. Assessment of occupational stress. In: Karinover M, editors. Epidemiology of occupacional health. (WHO-Regional Públications, European, Series, 20). Copenhagen: WHO Regional Office for Europe; 1986.

Karasek R E, Theorell T. Health work: stress, productivity and the reconstruction of working life. New York; Academic Press 1990.

Kerbal A. La genèse du mode dégradé en milieu industriel: étude dans l'industrie papetière algérienne. Paris;1989. [Tese de Doutorado em Ergonomia - CNAM].

Koller M. Health risks related to shiftwork. An example of time contingent effects of longterm stress. Int Arch Occup Environ Health; 1983; 53:59-75. 
Lacaz FAC. Saúde dos trabalhadores: cenário e desafios. Cad Saúde Pública.1997; 13 Supl. 2:7-19.

Lamourex T. The influence of aircraft proximity data on the subjective menta workload of controllers in the air traffic control task. Ergonomics; 1999; 42(11):1482-91

Landau K, Imhof-Gildein B, Mücke S. On the analysis of sector-related and gender-related stresses at workplace-An analysis of AET data bank. Internacional Journal of Industrial Ergonomics; 1996. (17) 175-186.

Laurell AC, Noriega M. Processo de produção e saúde: trabalho e desgaste operário. São Paulo: Hucitec; 1989.

Lefèvre F, Simioni AMC. Maconha, saúde, doença e liberdade: análise de um fórum na Internet. Cad Saúde Pública, Rio de Janeiro; 1998; 161-67.

Lefèvre F, Lefèvre AMC, Teixeira VJJ. O Discurso do sujeito coletivo: uma abordagem metodológica em pesquisa qualitativa. Caxias do Sul: Educs; 2000.

Lefèvre F. Passo a passo [on line] disponível no site http://www.fsp.usp.br/ flefevre em 20/04/2000.

Leplat J Cuny X. Introduction à la psycholoqie du travail, Paris: PUF; 1977.

Leplat J. Erreur humaine, fiabilité humaine dans le travail. Paris; A.Colin; 1985.

Leplat J De Terssac G. Les facteurs humains de Ia fiabilité dans les systèmes complexes. Marseille, Octrès, col. Enterprises; 1991.

Llory M. Accidents industriels: le court du silence; operateurs prives de parole et cadres introuvables. Paris: L'harmattan;1996.

Lucas Y. Le vol du savoir: techniciens de l'aeronautique et evolution des technologies. Lille: PUL; 1989.

Luna TD French J, Mitcha JL. A Study of USAF air traffic controller shiftwork: sleep, fadigue, activity and mood analyses. Aviat Space Environ Med.1997; Jan 68(1): 18-23.

LunaTD. Air traffic controller shiftwork: what are the implications for aviation safety? A review. Aviat Space Environ Med. 1997; 68(1): 69-79.

Maia WG. Acidentes aeronáuticos: aspectos éticos e legais. Rev Médica Aeronáutica 1989; 39(1):23-8, Brasil.

Mattoso J. A desordem do trabalho São Paulo: Scritta; 1995.

Marstedt G. Saúde mental e automação: a propósito de um estudo de caso no setor ferroviário. Cad Saúde Pública 1997; 13: 95-109.

Meira A.R. Estudo dos fatores contribuintes para a ocorrência de acidentes com aeronaves de pequeno porte e o aparecimento de lesões corporais em seus ocupantes, no período de 1971 a 1977 na área do Estado de São Paulo, Brasil. Rev IATROS; (2):33-8, 1983

Mendel G. Atepouvoir-et-aliénation-perspectives-socipsychanalytiques. In: Dejours C, Veil C, Wisner A. Psycho phatologie du travail. Paris: Enterprise Modern d’Édition; 1985. p:140-56.

Mendes R, Dias EC. Da medicina do trabalho à saúde do trabalhador. Rev. Saúde Pública 1991; 25:341-9.

Mendes R; organizador. Patologia do trabalho. Rio de Janeiro: Atheneu; 1995. 
Mendes R. Cidades saudáveis no Brasil e os processos participativos: os casos de Jundiaí e Maceió. São Paulo; 2000. [Tese de Doutorado - Faculdade de Saúde Pública da USP].

Millot P. Human machine cooperation: metaphor or possible reality? Manchester; 1977.

Minayo MC. O Desafio do conhecimento: pesquisa qualitativa em saúde. $4^{\mathrm{a}}$ ed. São Paulo: Hucitec / Rio de Janeiro: /Abrasco; 1996.

Minayo GC, Thedim-Costa SMF. A construção do campo da saúde do trabalhador: percurso e dilemas. Cad Saúde Pública 1997; 13 Supl. 2:21-32.

Ministério da Saúde. Norma Operacional de Saúde do Trabalhador- NOST-SUS, Diário Oficial da União, Brasilia, 10 nov; 1998. Seção 1, p. 17.

Mohler, SR The human element in air traffic control: Aeromedical aspects, problems, and prescriptions. Aviat Space Environ Med 1983; 54(6):511-16.

Monk TH, Tepas DI. Shift work. In: Cooper CL, Smith MJ, editors. Job stress and blue collor work. New York; John Wiley \& Sons; 1985. p 65-84

Moreira Neto G. Homeopatia em uma Unidade Básica de Saúde (UBS): Um espaço possível. São Paulo; 1999. [Dissertação de Mestrado- Faculdade de Saúde Pública da USP].

Moreira SB Cosendey AE Vidal MC. Aspectos bioquímicos e hematológicos de radaristas e alterações após uma jornada de trabalho no Controle de Tráfego Aéreo do Rio de Janeiro. In: Relatórios de Pesquisas Ergonômicas Realizadas no Controle de Tráfego Aéreo do Rio de Janeiro (APP/RJ), em 1999. COPPE/UFRJ. Rio de Janeiro; 1999. p.64-83.

Murphy E, Dingwall R, Greatbatch R. Qualitative research methods in health technology assessment: a review of the literature. Health technology assessment 1998; 2: 1-274.

Oddone I, Marri G, Gloria S, Briante G, Chiattella M, Re A. Ambiente de trabalho: a luta dos trabalhadores pela saúde. São Paulo: Hucitec; 1986.

[OPS] Organización Panamericana de la Salud Programa de acción em la salud de los trabajadores. Washington (DC);1983.

Ottawa Charter for Health Promotion. Health Promotion; 1997; 1:405-62.

Otway HJ. Public wisdom, expert fallibility: toward a contextual theory of risk. In: Social Theories of Risks. S. Krimsky \& D. Golding, editors, pp. 216-228. London: Praeger; 1992.

Passou no teste. Aero Magazine 1999 (67): 64.

Pépin M. L'Organization du travail posté. Paris: De L'anact; 1987.

Perrow C. Normal accidents-living with high-risk technologies. New York: Basic Books; 1984.

Petroski H. To engineer is human. The role of failure in successful design. New York: Vintage Books; 1992.

Pinsky L. Theureau J. Analyse du travail de saisie-chiffrement. Paris: CNAM/ LPTE; 1981.

Piovesan A Temporini E R. Pesquisa exploratória procedimentos metodológicos para o estudo de fatores humanos no campo da saúde pública. Rev Saúde Pública 1996; 29: 31825 .

Pomian K. L'ordre du temps. Paris: Gallimard; 1984.

Porto MF, Freitas CM. Análise de riscos tecnológicos ambientais: perspectivas para o campo da saúde do trabalhador. Cad. Saúde Pública 1997; 13 Supl. 2:59-72. 
Rasmussen J. Human errors. A taxionomy for describing human malfunction in industrial installation. J Occup Accidents 1982; 4: 311-33.

Reason J. The human error. London: Taylor and Francis; 1990.

Rohmert W, Landau K. A new technique for job analysis. London and New York, Taylor \& Francis Ltd. 1983.

Rosa LP. Os Riscos tecnológicos e a queda do Boeing na Amazônia. Contato 1989; (155).

Rotenberg L. Dormindo de dia e trabalhando à noite. São Paulo; 1997. [Tese de Doutorado- Instituto de Psicologia da USP].

Rutenfranz J. Occupational health measures for nigth and shiftworkrs. Procedings of $6^{\text {th }}$ International Symposium on Night and Shift Work. J Hum Ergol; 1982;1 1Suppl:67-86.

Rutenfranz J Haider M Koller M. Occupational health measures for nightworkers and shiftworkers. In: Folkard S, Monk. TH, editors. Hours of work. Temporal factors in workscheduling. Chichester: John Wiley\&Sons; 1985; p.199-10.

Rutenfranz J, Knauth P, Fischer FM. Efeitos dos turnos nas pessoas. Trabalho em turnos e noturno. São Paulo: Hucitec; 1989.

Rylander R Bjorkman M Ahrlin U Arntzen E Solberg S. Dose-response relationships for traffic noise and annoyance. Arch environ health; 1986; 41(1):7-10.

Sampaio JS. A importância do médico na investigação de acidentes aeronáuticos. Arq Bras Med Aer; 1989 (3): 17-22.

Sanz AS, Garcia AM, Garcia A. Road traffic noise around schools: a risk for pupil's performance. Int Arch Occup Environ Health; 1993; 65(3):205-7.

Schmitz H, Carvalho RQ. Automação de Base Microeletrônica, Competitividade e Trabalho. In: Schmitz H Carvalho RQ. Automação, Competitividade e Trabalho: A Experiência Internacional. São Paulo: Hucitec; 1988. p. 7-11.

Schraiber LB Mendes-Gonçalves RB. Necessidades de Saúde e Atenção Primária. In: Mendes-Gonçalves RB, Nemes MIB, Schraiber LB. Saúde do Adulto: Programas e Ações na Unidade Básica. $3^{\text {a }}$ ed.São Paulo: Hucitec; 1996. p. 29-65.

Sega R, Cesana GC, Costa G, Ferrario M, Bombelli M, Mancia G. Ambulatory blood presure in air traffic controllers. Am J of Hypertension 1998;11:208-212.

Selligman-Silva ES. Desgaste mental no trabalho dominado. Rio de Janeiro - UFRJ/São Paulo: Cortez; 1994.

Selligman-Silva ES. Saúde mental e trabalho. In: Tundis SE, Costa N Organizador Cidadania e Loucura: Políticas de Saúde Mental no Brasil. Petrópolis: Vozes; 1987; 217 88.

Selligman-Silva ES. Psicopatologia e psicodinâmica do trabalho. In: Mendes, R. organizador Patologia do trabalho. Rio de Janeiro: Atheneu; 1995; p.287-10.

Selligman-Silva ES. Saúde mental e automação: a propósito de um estudo de caso no setor ferroviário. Cad Saúde Pública 1997; 13: 95-109.

Sevá O. Urgente: combate ao risco tecnológico. Cad FUNDAP 1989; 16: 74-83.

Silva LF. Acidentes de trabalho com máquinas: Estudo a partir do sistema de vigilância do programa de saúde dos trabalhadores da Zona Norte de São Paulo, em 1991. São Paulo; 1992. [Dissertação de Mestrado - Faculdade de Saúde Pública da USP]. 
Silva VP, Baggio G. Transporte aéreo, sinônimo de soberania. Folha de São Paulo 1999 ago $1 ;$ cad 1:3.

Simione AMC. O gerenciamento de recursos humanos com processo social. São Paulo; 1996. [Dissertação de mestrado-Faculdade de Saúde Pública da USP]

Singleton WT, Hovden J, editors. Risk and decision. London: John Wiley \& Sons; 1987.

Slagle DA, Reichman M, Rodenhauser P, Knoedler D, Davis CL. Community psychological effects following a non-fatal aircraft accident. Aviat Space Environ. Med 1990; 61: 879-86.

Spencer MB. The influence of irregularity of rest and activity on performance: a model based on time since sleep and time of the day. Ergonomics 1987; 30:1275-86.

Stoynev AG, Minkova NY. Laboratory of work phsysiology. Transport Medical Institute, Sofia: Bulgaria. Occup Med Oxf 1997; 47:151-4.

Stoynev AG Minkova NY. Effect of forward rapidly rotating shiftwork on circadian rhythms of arterial pressure, heart rate and oral temperature in air traffic controlers. Occup Med Oxf 1998; 48: 75-9.

Soliani A. Governo faz autocrítica sobre crise no ar. Folha de São Paulo 2000 maio 6; cad 2:4.

Swain A D. Human Factors associated with prescribed action links. Sandia Laboratories, SAND, USA.1974; 74-0051.

Tanquini B Cecchetin M Caridi A. Serum gastrim and pepsinogen in shiftworkers. Int Arch Occup Environ Health 1986; 58:99-103.

Teixeira JJV. A prescrição medicamentosa sob a ótica do idoso. São Paulo; 1999.[Dissertação de Mestrado Faculdade de Saúde Pública da USP].

Tepas DI, Mahan RP. The many meanings of sleep. Work \& Stress 1998; 3:93-102.

Torswall I, Akersted T, Gillberg M. Age, sleep and irregular work hours. A field study with elestroencephalografic recordings, catecholamine excretion and self ratings. Scand $\mathbf{J}$ Environ Health; 1981; 7:196-203.

Vasconcellos LCF, Ribeiro FSN. A Pesquisa epidemiológica no processo de vigilância em saúde do trabalhador, III Cong. Bras. Epidemiologia. Oficina de trabalho "Estágio atual e perspectivas na investigação epidemiológica em saúde do trabalhador". Salvador: BA; 1995.

Vener KJ, Szabo S, Moore JG. The effect of shiftwork on gastrointestinal(GI) function: a review. Chronobiologia 1989;16:421-39.

Vidal M.C. A evolução conceitual da noção de causa de acidentes do trabalho. In: Anais do IV ENEGEP 1984 ; Piracicaba, Brasil.

Vidal M.C. Abordagem da engenharia de segurança do ponto de vista dos paradigmas em ergonomia. Grupo de Ergonomia e Novas Tecnologias da COPPE/UFRJ.1997. [on line] Disponível em <URL:http://www.gente.ufrj.Br/ rsp>[2000 Abril 23].

Vidal MC, Moreira SB. Relatórios de pesquisas ergonômicas realizadas no controle de tráfego aéreo do Rio de Janeiro (APP/RJ), em 1999. COPPE/UFRJ. Rio de Janeiro; 1999.

Walker J. Social problems of shiftwork. In:Folkard S, Monk TH editors. Hours of work: Temporal factors in work-scheduling. Chichester: John Wiley \& Son; 1985 p.211-25.

Weber M. Le savant et le politique. Paris: Plon; 1959. 
Wiener EL, Nagel DC, editors. Human factors in aviation. New York: Academic Press; 1998.

Wisner A. Por dentro do trabalho: ergonomia, método e técnica. São Paulo: FDT/Oboré; 1988.

[WHO] World Health Organization. Environment Health Criteria 137 Eletromagnetic Fields (300Hz to 300GHz) Geneva; 1993.

Wu TN, Lai JS, Shen CY, Yu TS, Chang PY. Aircraft noise, hearing ability, and annoyance Arch Environ Health 1995; 50: 452-6.

Wynne B. Risk assessment of technological system - dimensions of uncertainty. In: Risk Management and Hazardous Waste - implementation and dialects of credibility, B. Wynne editors. Berlin: Springer-Verlag 1987; p.269-310.

Wynne B. Sheepfarming after chernobyl - a case study in communicating scientific information. Environmental 1989; 31:10-15; 33-39.

Wynne B. Uncertainty and environmental learning - reconceiving science and policy in the preventive paradigm. Global Environ Change; 1992; 2:111-127.

Zuboff S. In the age of the smart machine. New York: Basic Books; 1988. 
TRANSCRIÇÃO DA FITA RELATIVA À MATERIA JORNALISTICA REALIZADA PELA RÁDIO *JOVEM PAN", EM 09/04/96, SOBRE AS CONDIÇÕES DE OPERAÇÃO NO AEROPORTO DE CONGONHAS

LOCLTORES PILOTO DA PONTE AEREA QLE DISCUTIL COM O CONTROLADOR DE VÔO DO AEROPORTO DE CONGONHAS NÃU SABIA O QUE ESTAVA FALANDO. E A CONCLUSÃO DO CORONEL DA RESERVA HELIO PEREIRA ROSA QUE FOI CHEFE DURANTE VARIOS ANOS. DO SERVIÇO DE VOOO DE SÃO PAULO. A JOVEM PAN APRESENTOU NESTA TERÇA FEIRA UM TRECHO DA CONVERSA DE LMI PILOTO COM A TORRE QLE COMPROVA OS TRANSTORNOS QUE VIVE CONGONHAS. A PISTA AUXILIAR DO AEROPORTO ESTA INTERDITADA PARA RECAPEAMENTO POR TEMPO INDETERMINADO SEGUNDO INFORMACOES DA INFRAERO. () TRAFEGO AEREO EM CONGONHAS IA E INTENSO E SE TORNA ANNDA MAIS COMPLICADO POR CAUSA DA SOBRECARGA DA PISTA PRINCIPAL. OS CONTROLADORES DE VOO FAZEM O POSSIVEL PARA AGILIZAR POUSOS E DECOLAGENS E DESSA FORMA EVITAR MAIORES ATRASOS A TORRE DE CONTROLE DE CONGONHAS ADOTA INCLUSIVE PADROES INTERNACIONAIS DIMINUTNDO A DISTANCIA ENTRE AS AERONAVES MESMO ASSIM ALGUNS PILOTOS DIVERGEM DESSA ATTTUDE, CONFORME CONSTATOU O REPORTER DA RADIO JOVEM PAN ROBERT ZWERDLING UM PILOTO DA PONTE AEREA QUE DECOLAVA EM CONGONHAS NA MANHA DESTA TERÇ'A FEIRA CHEGOU A DISCUTIR COM O CONTROLADOR DA TORRE, NO MEIO DA DISCLSSÃO. O PILOTO DE UM JATO QUE DECOLAVA ENTROU NA CONVERSA PARA DEFENDER OS CONTROLADORES

TORRE: "Vang $600 \mathrm{com}$ trem checado livre pousar of" com 10 nos

PILOTO 1: 90 com 10 nos. a pergunta foi ferta pelo 000 . esse pacirao de separacau esta vigorando agora al em São Paulo?

TORRE : Confirme a mensagem. nada entendido

PILOTO 1: O padrão de separaçăo de 3 milhas da cabeceura com aetonave a ser autorizado para decolag̣em. esta vigorando a agora em São Paulo"

TORRE. Senhor, a pressăo e muto grande para decolugenss e pousos. se eu for fazer dentro do regulamento o senhor $e^{s}$ o prumero a reclamar. Cunco milhas e o regulamentar. Porem São Pauio opera fora dos requiamentos para facilitar as aetonaves Porem, se os comandantes quserem que opere assim no padráo. nos poderemns operar no padrão. o senhor e o pnimeiro a reciamar ne porque ficara aqui temos mas de sú aeronaves so no pato para pousar. o seninor val ver quantas aeronaves estao prontas para decoiar

TORRE Maritia 400 decoiou 08 . chame 1108

PILOTO 2 Marilá acha que esta bom de mars está separacao. pode ate duminuu 
TORRE vrato Mariia, boa vagem

LOCLTOR I A DISCLSSAO DOS DOIS PILOTOS COM A TORRE. DE CONGONHAS E LM BOM EYEMPLO DA SORRECARGA DE YOOOS NO AEROPORTO

LOCLTOR 2: COM A PISTA ALXILIAR INTERDITADA A PISTA PRINCIPAL DO AEROPORTO DE CONGONHAS FICOU AINDA MAIS CONGESTIONADA.

LOCLTOR I MAS O PILOTO NÃO TINHA NENHLMA RAZÃO PARA DISCUTIR COM O CONTROLADOR DE VOOO.

LOCLTOR 2. E O QUE CONCLLIU O CORONEL DA RESERVA HELIO PEREIRA ROSA, QUE FOI CHEFE DO SERVIÇO REGIONAL DE PROTEÇÃO AO VOO DE SAO PAULO

LOCLTOR 1. O CEL. CONCORDA COM O PROCEDIMENTO DA TORRE DE CONTROLE. QUE REDLZIL: A DISTÁNCIA ENTRE AS AERONAVES

LOCLTOR 2: FALANDO AO REPORTER ANDERSON LIMA. O CEL HELIO PEREIRA ROSA DIZ QUE A MEDIDA OBEDECE AS NORMAS INTERNACIONAIS DE SEGURANÇA.

CEL. HELIO PEREIRA ROSA - Enı condiçoes normass. Sáo utilizadas 5 milhas de distáncia entre uma aeronave e outra. mas a realidade por falta de manutençào das pistas. talvez eles tenham reduzido esta distancia para 3 milhas. Mas isso e uma condição intemacional. inclusive 3 milhas sân condições internacionais. $O$ que eu posso the dizer e o seguinte: a proteçào ao vóo de São Paulo e hoje uma das mais seguras da America Latina. E se houve a redução de 5 milhas para 3 milhas voce pode ter certeza que de maneira nenhuma a segurança foi fenda. $E$ eu the digo. conhecendo, como conheço, a proteção de São Paulo. eu the digo que se ela foi reduzida para 3 milhas ela poderia anda ser reduzida para 1.5 milha com toda a segurança possivel.

REPORTER - O Sr. acha que no caso do aeroporto de Congonhas. a distancia de 3 milhas entre pouso e decolagem. e uma distảncia segura."

CEL. HELIO PEREIRA ROSA - Olha. com toda certeza. se ela esta sendo usada para 3 milhas. pode ter certeza que a sequrança nào fol fenda em ponto nenhum. isso com toda a certeza

REPORTER - Não tena motivo então para essa teciamação do puloto?

CEL. HPR - De maneira nenhuma

ANCORA - O CEL. HPR OUE ACABAMOS DE OLVIR NESTA ENTREVTSTA. ELE DESTACA OLE O PROCEDIMENTO DA TORRE DE CONGONHAS E O CORRETO PARA E!TTAR COYGESTIONAMENTOS W TRAFEGO AEREO. E SEM I REDLCAO DA DISTANCIA ENTRE AS AEROYAVES OS CONGESTIONAMENTOS EM CONGONHAS PODERIAL! AFETAR ATE MESMO U AEROPORTO DO GALEAO NO RIO DE JA.:EIRO 

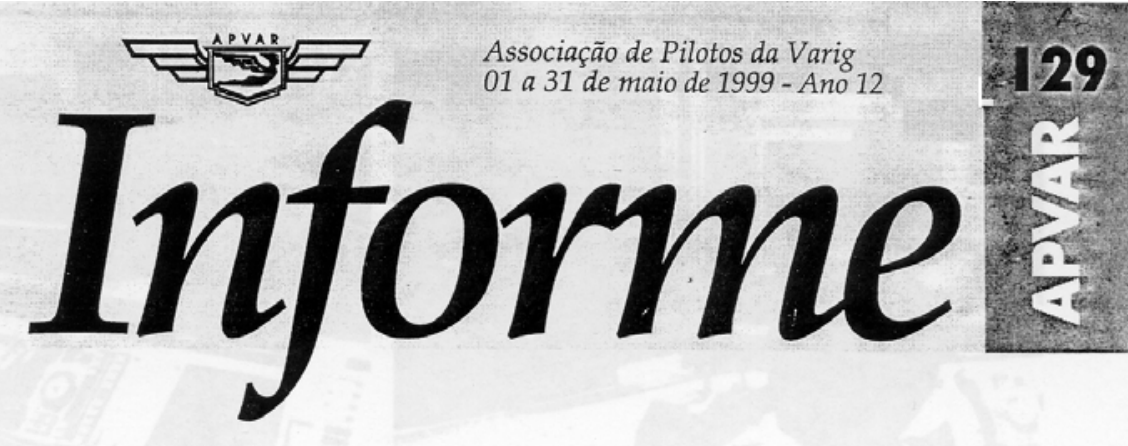

\section{Condições dos controladores afeta segurança de vôo}

O Instituto de Biociências da Universidade Estadual Paulista de Rio Claro - UNESP, juntamente com o Centro de Referência em Saúde do Trabalhador da Secretaria da Saúde do Estado de São Paulo - CEREST/SP realizaram, no último dia 26 de abril, o Painel de Debates "Saúde no Controle do Tráfego Aéreo à Qualidade de Vida nas Cidades". O evento, que aconteceu no Auditório da UNESP em São Paulo, contou com a presença de pesquisadores e profissionais que apresentaram estudos, ainda em fase inicial, sobre as condições de trabalho dos controladores de tráfego aéreo.

Entre eles, esteve Rita Araújo, que tem recebido apoio da APVAR para participar de eventos relativos às condições de trabalho dos Pilotos. Ela cita que, somente na Terminal São Paulo, houve um au- mento de $230 \%$ do tráfego aéreo nos últimos seis anos, destacando o Aeroporto de Congonhas e Campo de Marte que tiveram um aumento de $280 \%$ nesse período. Verificou-se, então, um aumento da intensidade e densidade do trabalho dos controladores, que ainda não contam com um sistema informatizado de gestão de tráfego. "Além disso, por falta de recursos humanos, estes profissionais estão trabalhando com a metade do quadro de pessoal e enfrentam duras dificuldades como a falta de planos de saúde e carreira, o que pode afetar a segurança das operações de vôo", detalha.

Os representantes do Ministério Público Federal, presentes no debate, se comprometeram a acompanhar os estudos, bem como o aumento do tráfego dos aeroportos urbanos paulistanos. 


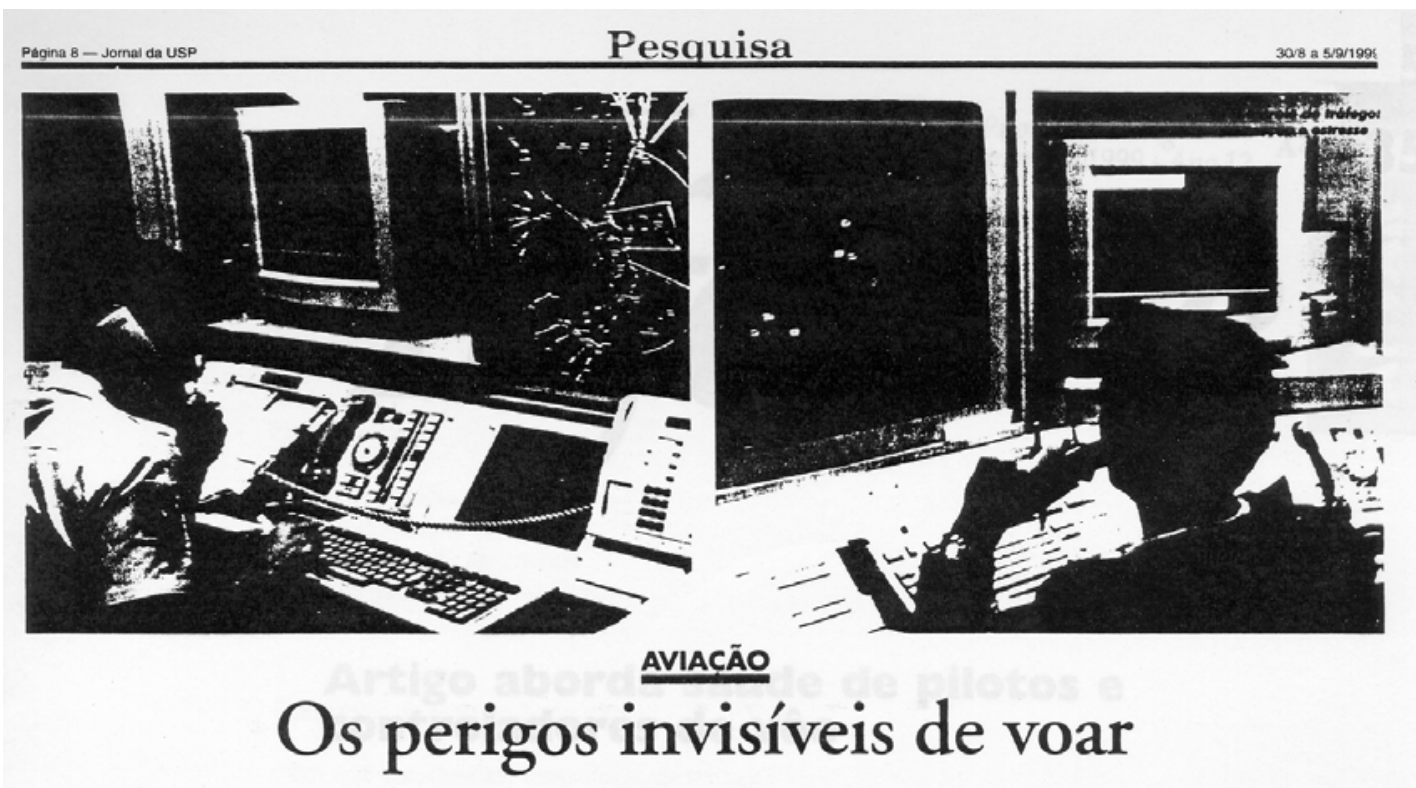

Pesquisa do Departamento de Saúde Ambiental da Faculdade de Saúde Pública mostra que as condições de trabalho na aviação civil comprometem a segurança do serviço e a saúde dos profissionais

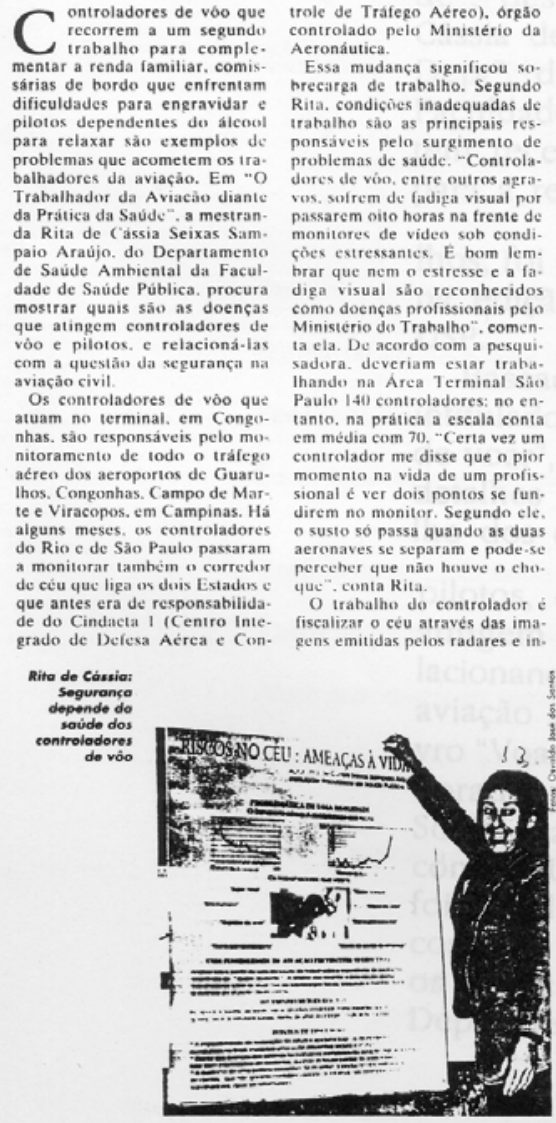

\section{- MARIANA FERREIRA}

tervir quando necessário. ou
quando solicitado pelo piloto. controlador de vóo éo o braço di-
reito do piloto no solo. O conreito do piloto no solo. O con-
trole de aproximaçắo e decolagem das acronaves nas areas ter. do controle de tráiego. indepen. dente das condiçoes de visibil. a cebectira da pista passinge comandada pela torre, onde ouIros controladores operam sob A comunicaçào entre pilotos c controladores de vòo, portanto. deve ser a mais clara possivel. Rita conta, no entanto. que nos depoimentos que colheu junto a éncia no inglés é raridade entr as controladores de voo e yue pánico quando nào consefuem se comunicar com um piloto de ou. mo $\mathrm{cm}$ portugués podem sureir situaçóes difíceis. "Eu disse vire 180 graus a esquerda. ele enten deu proa 1 ko graus. Muitas ve. res o pilero nár repece o coman. disse um controlador de vóo durante o evento "Da saude no con. frole de traficgo acreo a qualit. ocorreu em abril no auditorio do Conselho Uiniversitário da Unesp Universidade Estadual PaulisNesses très anos. Rita também articipa de um grupo de pes-
uisa da Unesp na area de ris. cos no transporte. A mestranda do trabalho sáo, na maioria das do trabalho sio. na maioria das
vezes. decorrentes do estresse. A pesquisadora acredita que as más condiçós de trabalhò -
nos horários de pico cada con nos horários de pico cada con-
trolador da Area Terminal Sáa Paulo monitora cerca de 12 ac. ronaves. quando o idcal seria de tio $\mathrm{e}$ o estresse mental c fisic provocado pelas mudanças sepundo trabal ho ocasionam o prohicmas de saúde, "As condi- estressantes. Chega um ponto
que vocé comeca a ser ultrapas. sado pelas aeronaves. aí vocé Iou um controlador de vóo que do com a pesquisadora da Fa. culdade de Saude Pública, mulos controladores sâo militares se identificar por temerem te. presálias.

Rita aponta um outro proble. ava que pace em risco a segurança esaria em média de quatro anos e estudo para desenvolver todas a atribuiçies na frente do ternide muitos profissionais. estão sendo empregados jovens com

$$
\begin{gathered}
\text { Saúde } \\
\text { dos pilotos }
\end{gathered}
$$

Apesar de existir no Sindicato Nacional dos Aeronautas (SNA) of dados ofliciais sobre os pessoal que voa. Ate porque
por quemi sc encarrega dos exames a publicos os resultados. "Queremos implantar, seguindo a re comendacho do Ministerio do Saude, exames médicos preven-
tivos $\mathrm{e}$ periódicos sem que haja necessidade de compensacâo em dia de trabalho". diz Aguinaldo
Souza. secretário de Saúde do

sando os dados das empre. as seguradoras hrasileiras de
990 a 1995 sohre os casos que levaram pilotos a perderem o dique os probicmas cardiovassulaquibitrcok. assim como a Sindrome de imunodeficiéncia Adquiri. Os restantes $24.44 \%$ estâo distribuidos nos sequintes casos
morbidade: cancer. problemas morbidade: cancer. probiemas e outros não especificados. Pesestud ex-pilotos estejam morrendo de reta dos raios solares durante o tempo em que voaram acima de 35 mil pt's

Assim como os controladores jornada do urabathe irrepulas. Depois de voarem por seis dias. os pilotos voltam para casa. pas. Jem ser ofiesalmente cuinte popara mais uma sequéncia de seis dias voando. $O$ resuitado sảo al. teraçóes drasticas no ritmo bio. logico e desarticulacía da vida lia. Além de probiemas de fadi. ga. de depressáo e gastrointesti-

No seu livro Voando com os do trabaliho da Fundacío Rogétio Duprat, traz depoimentos que mostram como a vida pro hissional interiere na pessoal. Pi. chotel em hotel e ques au vida aposentam sentem-se sobran. o, porque a tamilia já organi. ou tudo sem eles. "Periodos dade e depressão, que muitas vecs levam ao alcoolismo-" diz A Varig é uma das primeiras mostrar preocupacáo requar e da tripulaçáo. Os vốos que partem do kio de Janeiro para Nagóia. no Japào. com escala em Litoranceles. passara. a ter mo. cós desses vóos passam por 13 usos horários. Năe há organismo Que resista a iso. comikarias che. es por mis". conta Sio a tres ve Para Rita. as empresas de avia. ros com a xaúde de ceus empregados quando o Simisicrio da $\mathrm{Ac}$. transparéncia. mostrando para sociedade os riscos de segurancha que existem no sistema de tráfe. go acreo civil 


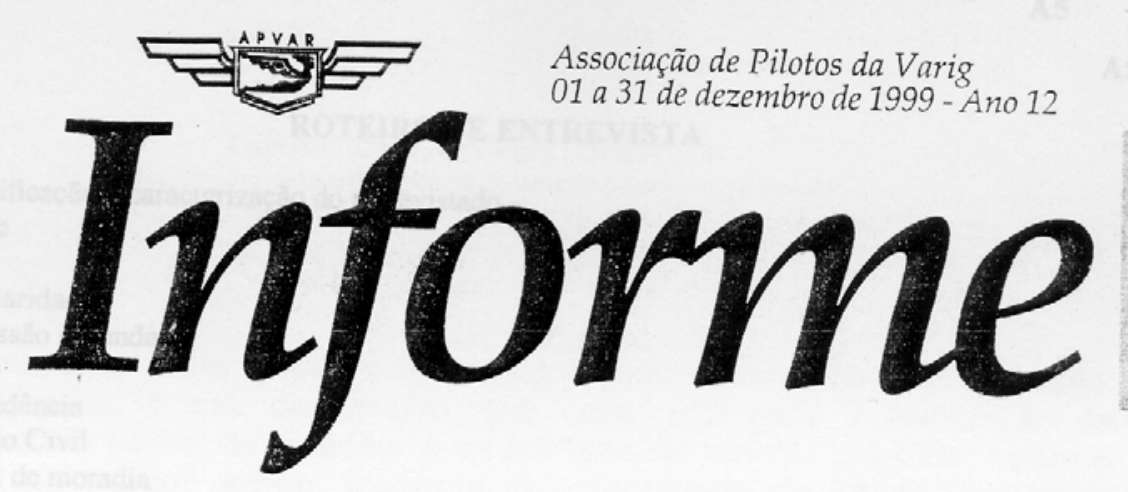

\section{Artigo aborda saúde de pilotos e controladores de vôo}

\footnotetext{
A pesquisa "O Trabalhador da Aviação Diante da Prática da Saúde", desenvolvida por Rita de Cássia de Araújo, mestranda do Dept $^{2}$. de Saúde Ambiental da Faculdade de Saúde Pública que tem recebido apoio da APVAR para a realização de seus traba-

lhos, foi objeto de ampla matéria na edição $\mathrm{n}^{2} 484$ do Jornal da USP.

Baseado na pesquisa, o artigo intitulado "Os perigos invisíveis de voar", aborda com riqueza de detalhes as condições de trabalho dos controladores de vôo e pilotos, e as doenças que mais atingem estes profissionais, relacionando-as com a segurança na aviação civil. O conteúdo do livro "Voando com os Pilotos", elaborado pelo Depto. de Serviço Social da APVAR em conjunto cóm a FUNDACENTRO, também foi abordado na matéria, que encontra-se à disposição de todos os associados interessados no Dept $^{\circ}$. de Comunicação.
} 


\section{ANEXO 5 - ROTEIRO DE ENTREVISTA}

\section{Identificação e caracterização do entrevistado -}

Nome

Sexo

Escolaridade

Profissão secundária

Idade

Procedência

Estado Civil

Local de moradia

Tempo na Função (CTA)

Tempo na função secundária

Horários de Trabalho

Salário

\section{Condições de realização do trabalho -}

Por que escolheu ser controlador de tráfego?

O que você acha das condições de trabalho no CTA?

- Operação equipamentos

- Ambiente físico: iluminação, ruído, temperatura ambiente

Como você se sente após uma jornada de trabalho no CTA?

- Organização do trabalho

- Pausa para descanso

- Trabalho em turno alternado

- Horários de picos e vales

3. Cotidiano de Vida do controlador de tráfego aéreo

Como é no seu dia a dia a relação com a família?

Você pratica algum esporte ou tem alguma atividade de lazer regular?

Como você cuida de sua saúde em termos de horários de refeições e sono?

4. Práticas de saúde da instituição

Como foi o seu exame admissional?

Você pode descrever como é o exame periódico realizado pelo HASP?

Qual a sua opinião sobre os exames realizados pelo HASP?

5. Você vê possibilidade de mudanças na sua realidade de trabalho 


\section{ANEXO 6- CONSTRUÇÃO DO INSTRUMENTO DE ANÁLISE DE DISCURSO 1 (IAD 1)}

Neste Quadro Ilustrativo exemplificam-se os passos metodológicos seguidos para cada uma das 5 questões do Roteiro da Entrevista, de onde se identificam as Idéias Centrais e as correspondentes Expressões Chaves estabelecidas de acordo com os objetivos da pesquisa.

Questão 1: O que você acha das condições de trabalho no APP?

\section{Idéia Central}

O trabalho.exige $100 \%$ de

atenção.

$\mathrm{O}$ sistema mudou

externamente, mas continua

tecnológica-mente

desatualizado

gerando

insegurança nos

controladores.

É uma falsa

modernidade para

ser mostrada na

mídia.

Os controladores

têm que se adequar

a um sistema falido

sem poder

manifestar sua

opinião.

\section{Expressões Chaves}

O trabalho exige muita habilidade, vigilância e percepção. Você tem que estar cem por cento, inteiramente ligado àquilo que você está fazendo.

Com esse sistema novo... o pavão ficou bonito, mas o interior é o mesmo, as dificuldades que nós tínhamos antes, estamos tendo ainda, vamos continuar a ter. Existe insegurança com certeza. Você está sempre trabalhando com aquela dúvida... Você faz uma segurança que era feita desde a época de Santos Dumont

Eles estão preocupados com a imprensa que vai lá, e filma... agora é novo. Antes a sala era escura, agora é clara, é colorido, então, para a imprensa é bonito. A imprensa mostra... o antigo e mostra um totalmente moderno, atual, mas vamos dizer... é só a casca, porque o restante é o mesmo. É uma falsa modernidade

....mas o que a gente sofre lá dentro não é uma coisa que eles estão preocupados. $\mathrm{O}$ aumento do volume de trafego e o aumento da velocidade das aeronaves. Você é considerado um incompetente dentro do seu serviço, porque você disse a pessoa àquilo que ela não gostaria de ouvir... que aquilo está corroído, que aquilo não serve mais, que está arcaico, que é realmente a falência do controle de trafego aéreo, e a pessoa não quer acreditar nisso. 
ANEXO 7 - CONSTRUÇÃO DO INSTRUMENTO DE ANÁLISE DE DISCURSO 2 (IAD 2)

Neste Quadro Ilustrativo demonstra-se o processo de agrupamento das Idéias Centrais que se coadunam sob um mesmo tema, de acordo com os objetivos estabelecidos. Da mesma forma, são reunidas as correspondentes Expressões-Chave, que se constituem, então, no Discurso do Sujeito Coletivo. Este procedimento é realizado por meio da análise das questões (5), do Roteiro da Entrevista, e para os 12 entrevistados.

IAD 2
Idéia Central 1
O trabalho é Fantástico
O trabalho.exige atenção total. É uma
profissão fascinante. A paixão pelo controle
de trafego aéreo se revela enquanto um
prazer imenso pelo serviço. É um dos poucos
trabalhos que você não tem que trazer nada
para casa. Quando termina... é um alívio.
Trabalhar naquilo que se gosta é um dom de
Deus, é um prêmio, é uma realização, uma
fonte de prazer.

DSC do Trabalho Fantástico
É uma atividade encantadora... muito bonita,
porque você trabalha com pessoas, você está
sempre se comunicando. Sua função primordial é
cuidar da integridade física de muitos e isso é
gratificante, principalmente quando você
consegue resolver todos os problemas que
surgem em momentos inesperados. A emoção
que traz o trabalho com fluxo de tráfego grande é
fantástica... você está ali ligado, esquece de tudo,
dá um bloqueio de toda a tua vida. Você está ali,
como se você jogasse um vídeo game... Você é
parte daquilo, é um momento de ficção. É
fascinante mas não são todos que se adaptam
obviamente... Eu adoro o que faço. É aquele
negócio... se existe amor a primeira vista...
comigo foi nisso aqui. Se eu saísse daqui, ainda
hoje, apesar de tudo, eu ia me sentir tipo uma
viúva, que perdeu um grande amor, é mais ou
menos por aí. Sinto um prazer imenso nesse
serviço, levanto venho legal pra cá... não tenho o
menor problema de vir para cá, se eu pudesse
ficaria cinqüenta anos... eu ficaria... pelo serviço.
O ambiente aqui me faz muito bem. Também
sempre saio bem daqui... me esqueço de tudo lá
fora enquanto trabalho aqui... e para mim é
sempre um prazer. Ajudar... um avião perdido,
você se sente bem com isso... Eu sempre gostei
sempre pensei que isso é um dom de Deus, todo
mundo tem que trabalhar, mas trabalhar naquilo
que você gosta.... Então é claro, quando dá
alguma coisa errada eu fico triste, chateado,
agoniado... mas na maioria das vezes, no geral,
no balanço que eu faço é que sempre é muito
prazeroso... muito bom para mim.




\section{TERMO DE CONSENTIMENTO}

(de acordo com resolução n. 196/96 do Conselho Nacional de Saúde) ${ }^{\circ}$

Venho através deste solicitar o seu consentimento para registrar em gravação, em fita magnética, o seu depoimento, que contribuirá para a elaboração da pesquisa: $O$ trabalhador da aviação e as práticas de saúde: um olhar sobre o controlador de tráfego aéreo, realizada pela Faculdade de Saúde Pública da Universidade de São Paulo.

O objetivo desta pesquisa é levantar as condições de saúde e trabalho dos controladores de tráfego aéreo do Controle de Aproximação de Tráfego, localizado no Aeroporto de Congonhas em São Paulo, para contribuir ao debate da qualidade de vida no trabalho e segurança da aviação.

Esclareço que será mantido o sigilo sobre todas as informações prestadas, assim como, o anonimato e independência em relação a hierarquia da instituição, não implicando a participação neste trabalho em risco de nenhuma natureza; sendo garantido, ainda, o direito de desistência ao participante em qualquer fase da pesquisa.

O pesquisador se comprometerá a devolver os dados e discutir com os envolvidos as possíveis formas de melhoria da qualidade de vida no trabalho e suas implicações para a sociedade.

Concordo em participar da pesquisa.

assinatura

Contato: Rita Araújo Fone. 36736372 
A1

A2

A3

A4

A5

A6

A7

A8

A9 